A METHOD FOR ESTIMATING GROUND-WATER RETURN FLOW TO THE LOWER COLORADO RIVER IN THE YUMA AREA, ARIZONA AND CALIFORNIA

By O. J. Loeltz and S. A. Leake

U.S. GEOLOGICAL SURVEY

Water-Resources Investigations Report 83-4220

Prepared in cooperation with the U.S. BUREAU OF RECLAMATION 


\section{UNITED STATES DEPARTMENT OF THE INTERIOR \\ WILLIAM P. CLARK, Secretary}

GEOLOGICAL SURVEY

Dallas L. Peck, Director

For additional information write to:

District Chief

U.S. Geological Survey

Box FB-44

Federal Building

301 West Congress Street

Tucson, Arizona 85701
Copies of this report can be purchased from:

Open-File Services Section Western Distribution Branch U.S. Geological Survey Box 25425, Federal Center Denver, Colorado 80225 Telephone: (303) 234-5888 


\section{PREFACE}

This report presents a method for estimating the amount of ground-water return flow to the Colorado River in the Yuma area, Arizona and California. To accommodate a wide range of reader interest, the report is divided into two parts. Part 1, the executive summary, discusses how the study was developed and presents return-flow estimates for 1975-78. Part II, the technical discussion, presents the method for estimating ground-water return flows and the results of the study. The executive summary is published separately as U.S. Geological Survey Water-Resources Investigations Report 83-4221 (Loeltz and Leake, 1983) for readers interested only in the general development of the study and the results. 


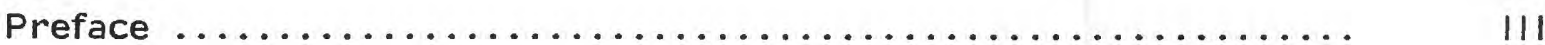

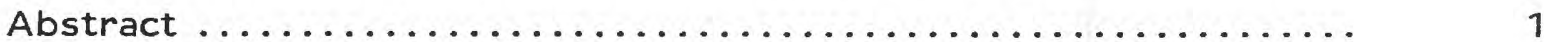

PART I - EXECUTIVE SUMMARY

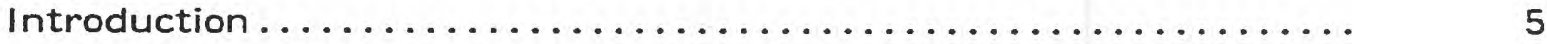

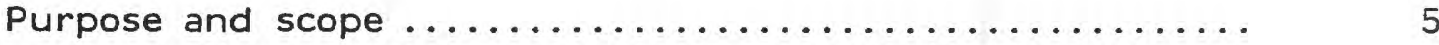

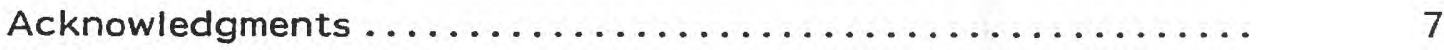

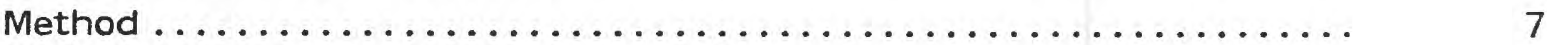

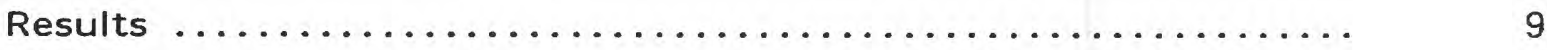

Future decisions $\ldots \ldots \ldots \ldots \ldots \ldots \ldots \ldots \ldots \ldots \ldots \ldots \ldots \ldots \ldots \ldots \ldots \ldots \ldots$

PART II - TECHNICAL DISCUSSION

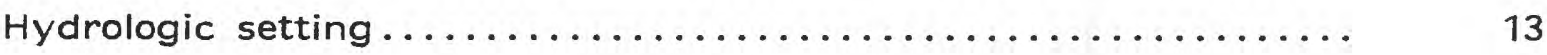

The Colorado River and adjacent land ............... 13

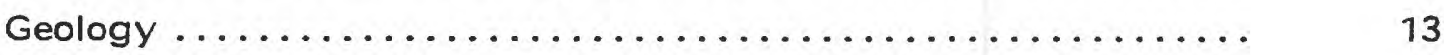

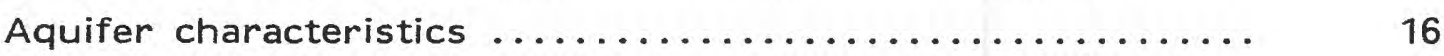

Ground-water movement ........................ 17

Method .................................. 20

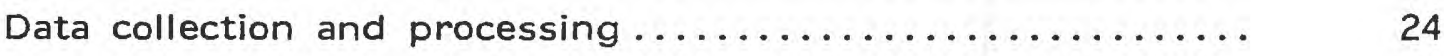

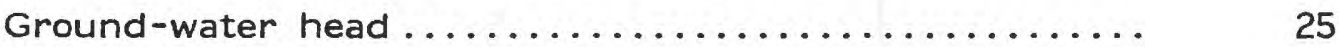

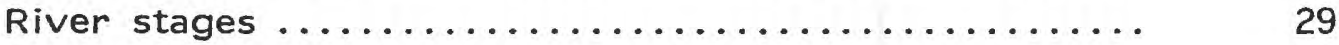

Specific yields ........................ 29

Models of the system ................................ 31

Transient-flow models .................... 33

Grid dimensions ....................... 38

Input and output........................ 38

Calibration of the models .................. 56

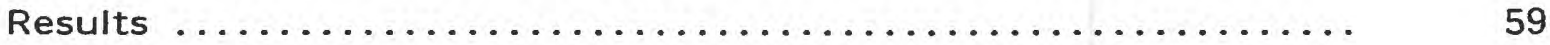

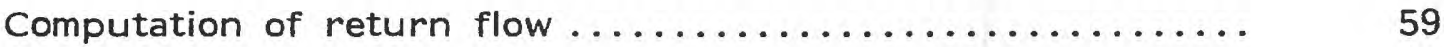

Future estimation of return flow ................. 83

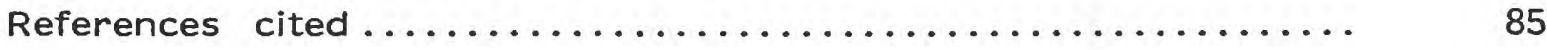


Figures 1-2. Maps showing:

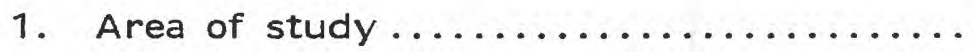

2. Estimated ground-water return flows to the Yuma reach of the lower

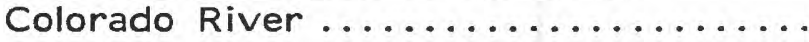

3. Graph showing comparison of estimated annual return flows in the Yuma reach, 1975-78 .....

4-5. Maps showing:

4. Cropland in the Yuma area, $1978 \ldots . . .$.

5. Water-table configuration in the Yuma area, December 1978 .............

6. Sketch showing typical cross section with steady-state boundary conditions used in the hydraulic-analysis method ...........

7-10. Photographs showing:

7. Instrumentation at a piezometer site ..... 26

8. Typical cluster of three piezometers ......

9. Programing unit attached to rear of digital recorder ............. 28

10. Typical river-stage station ............ 30

11-12. Graphs showing:

11. Selected soil-moisture profiles ..........

12. Effects of various ratios of $S_{0} / S_{y}$ on response of aquifer at location of piezometer $A Z 4 \ldots \ldots \ldots \ldots \ldots \ldots \ldots \ldots$

13-29. Model grids showing model dimensions and various hydraulic properties near piezometers for model of:

13. Cross section $18 \ldots \ldots \ldots \ldots \ldots \ldots \ldots \ldots \ldots$

14. Cross section $17 \ldots \ldots \ldots \ldots \ldots \ldots \ldots \ldots . \ldots \ldots$

15. Cross section $16 \ldots \ldots \ldots \ldots \ldots \ldots \ldots \ldots \ldots \ldots \ldots \ldots$ 
Figures 13-29. Model grids showing model dimensions and various hydraulic properties near piezometers for model of-Continued

16. Cross section $15 \ldots \ldots \ldots \ldots \ldots \ldots \ldots . \ldots \ldots$

17. Cross section $14 \ldots \ldots \ldots \ldots \ldots \ldots \ldots . \ldots \ldots$

18. Cross section $13 \ldots \ldots \ldots \ldots \ldots \ldots . \ldots . \ldots . \ldots$

19. Cross section $11 \ldots \ldots \ldots \ldots \ldots \ldots \ldots . \ldots \ldots$

20. Cross section $10 \ldots \ldots \ldots \ldots \ldots \ldots . \ldots \ldots$

21. Cross section $9 \ldots \ldots \ldots \ldots \ldots \ldots \ldots . \ldots \ldots$

22. Cross section $8 \ldots \ldots \ldots \ldots \ldots \ldots \ldots . \ldots \ldots$

23. Cross section $7 \ldots \ldots \ldots \ldots \ldots \ldots . \ldots . \ldots . \ldots$

24. Cross section $6 \ldots \ldots \ldots \ldots \ldots . \ldots . \ldots . \ldots$

25. Cross section $5 \ldots \ldots \ldots \ldots \ldots \ldots \ldots \ldots \ldots$

26. Cross section $4 \ldots \ldots \ldots \ldots \ldots \ldots . \ldots \ldots$

27. Cross section $3 \ldots \ldots \ldots \ldots \ldots \ldots \ldots \ldots \ldots$

28. Cross section $2 \ldots \ldots \ldots \ldots \ldots \ldots \ldots \ldots \ldots$

29. Cross section $1 \ldots \ldots \ldots \ldots \ldots \ldots . \ldots \ldots$

30-46. Graphs showing observed and computed

head changes with time at:

30. Cross section 18 caused by river-stage event of August 14-17, $1973 \ldots \ldots \ldots .60$

31. Cross section 17 caused by river-stage event of August 14-17, 1973..........

32. Cross section 16 caused by river-stage event of August 14-17, $1973 \ldots \ldots \ldots$.

33. Cross section 15 caused by river-stage

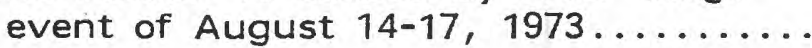

34. Cross section 14 caused by river-stage event of August 14-17, 1973......... 64

35. Cross section 13 caused by river-stage event of August 14-17, 1973..........

36. Cross section 11 caused by river-stage event of August 14-17, 1973.........

37. Cross section 10 caused by river-stage event of August 14-17, 1973........ 
Figures 30-46. Graphs showing observed and computed head changes with time at-Continued

38. Cross section 9 caused by river-stage event of August 14-17, 1973.........

39. Cross section 8 caused by river-stage event of August 14-17, 1973.........

40. Cross section 7 caused by river-stage event of August 14-17, 1973.........

41. Cross section 6 caused by riverstage event of February 28March 2, $1973 \ldots \ldots \ldots \ldots \ldots \ldots \ldots \ldots$

42. Cross section 5 caused by river-stage event of December 18-21, 1978 .......

43. Cross section 4 caused by river-stage event of August 14-17, 1973........

44. Cross section 3 caused by river-stage event of April 9-12, 1975...........

45. Cross section 2 caused by river-stage event of September 10-12, 1976......

46. Cross section 1 caused by river-stage event of October 20-23, $1972 \ldots \ldots \ldots$.

47. Graphs showing differences in return-flow rates for 1976 at cross sections in the Yuma reach computed on the basis of

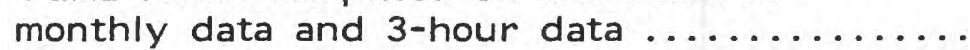

\section{TABLES}

Table 1. Estimated specific yields for return-flow cross

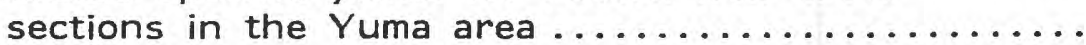

2. Average annual heads measured in piezometers

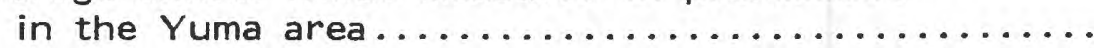

3. Differences between observed and computed average annual heads at near-cluster piezometer

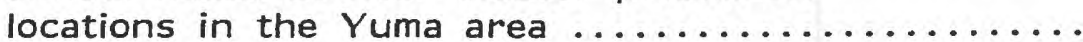

4. Estimated ground-water return flows to the

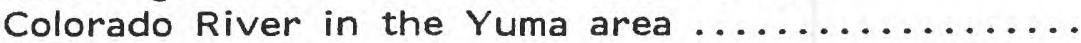




\section{CONVERSION FACTORS}

For readers who prefer to use metric units, the conversion factors for the terms used in this report are listed below:

Multiply

inch (in.)

foot $(\mathrm{ft})$

mile (mi)

acre-foot (acre-ft)

cubic foot per second $\left(\mathrm{ft}^{3} / \mathrm{s}\right)$

foot squared per day $\left(\mathrm{ft}^{2} / \mathrm{d}\right)$

foot per day (ft/d)

per foot $\left(\mathrm{ft}^{-1}\right)$
By

25.4

0.3048

1.609

0.001233

0.02832

0.0929

0.3048

3.28

\section{To obtain}

millimeter $(\mathrm{mm})$

meter $(m)$

kilometer ( km)

cubic hectometer $\left(\mathrm{hm}^{3}\right)$

cubic meter per second $\left(\mathrm{m}^{3} / \mathrm{s}\right)$

meter squared per day $\left(\mathrm{m}^{2} / \mathrm{d}\right)$

meter per day $(\mathrm{m} / \mathrm{d})$

per meter $\left(\mathrm{m}^{-1}\right)$

National Geodetic Vertical Datum of 1929 (NGVD of 1929): A geodetic datum derived from a general adjustment of the first-order level nets of both the United States and Canada, formerly called mean sea level. 


\title{
A METHOD FOR ESTIMATING GROUND-WATER RETURN FLOW TO THE LOWER COLORADO RIVER IN THE YUMA AREA, ARIZONA AND CALIFORNIA
}

\section{By}

O. J. Loeltz and S. A. Leake

\begin{abstract}
Substantial quantities of water diverted from the lower Colorado River in the Yuma area, Arizona and California, return to a reach of the river as ground-water flow. A method for estimating these quantities involves the computation of ground-water return-flow rates using hydraulic analyses of ground-water flow at 18 cross sections normal to the river. The cross sections are spaced about 1 mile apart over a reach of the river adjacent to irrigated land in the Yuma area.

The hydraulic-analysis method uses average annual gradients that are based on measurements of river stage and ground-water heads. Ground-water heads are measured in piezometers, which are about 100 and 500 feet from the river and near the top, middle, and bottom of a 100-foot-thick sand, silt, and clay aquifer that commonly overlies a highly permeable river-gravel bed. The method also uses estimated hydraulic-conductivity distributions to compute return-flow quantities. Hydraulic-conductivity distributions are estimated in part by trial-and-error calibration of transient cross-sectional models using the response of the aquifer to changes in river stage. Storage characteristics of the aquifer were inferred in part from soil-moisture studies using a neutron probe.
\end{abstract}

The average annual return flow for 1975-78 was estimated to be 44,000 acre-feet from lands on the Arizona side of the river and 38,000 acre-feet from lands on the California side. Estimates of total return flow for the Yuma reach compare favorably with estimates made using surface-water-budget and salinity-budget methods. 
PART I - EXECUTIVE SUMMARY 


\section{INTRODUCTION}

An investigation of the water resources of the lower Colorado River-Salton Sea area by the U.S. Geological Survey began in 1960. The investigation disclosed that along three reaches of the lower Colorado River substantial quantities of water that had been diverted from the river for irrigation were returning to the river as ground-water (subsurface) flow (Metzger and others, 1973; Olmsted and others, 1973). These reaches were later designated as the Parker reach, the Palo Verde-Cibola reach, and the Yuma reach (fig. 1).

The State of Arizona, in a letter dated September 22, 1969, officially protested to the Secretary of the Interior the practice that was being used by the U.S. Bureau of Reclamation in accounting for water use from the main stem of the Colorado River below Lees Ferry pursuant to Article $V$ of the decree by the U.S. Supreme Court (1964). The protest was mainly against the practice of charging diversions from the river less surface return flows to the river as consumptive use to each State. Arizona contended that the definition of "consumptive use" in the decree, which states "Consumptive use' means diversions from the stream less such return flow thereto as is available for consumptive use in the United States or in satisfaction of the Mexican treaty obligation, "included surface and subsurface return flow. The U.S. Department of Interior agreed that subsurface return flows should be included and immediately sought a means of determining the amount of subsurface return flow creditable to each state.

In 1970, representatives of the U.S. Geological Survey and the U.S. Bureau of Reclamation agreed on the scope and objectives of a project for estimating the amount of subsurface return flow. The project was to be a cooperative undertaking in which the U.S. Bureau of Reclamation would be responsible for the construction, installation, and maintenance of various equipment and features for data collection, and the U.S. Geological Survey would be responsible for the instrumentation, data collection, and determination of the ground-water return-flow quantities. The Task Force On Unmeasured Return Flow to the Lower Colorado River was formed to provide guidance on the scope and objectives of the investigation and to provide an avenue of communication among all interested agencies during the investigation. The task force is composed of representatives of the States of California, Arizona, and Nevada; Federal Indian Agencies; the U.S. Bureau of Reclamation; and the U.S. Geological Survey.

\section{Purpose and Scope}

The purpose of this study was to develop a method for estimating the amount of subsurface return flow to the Colorado River in the Yuma area. This report presents a method that permits an approximate accounting of ground-water return flow from each side of the Colorado 


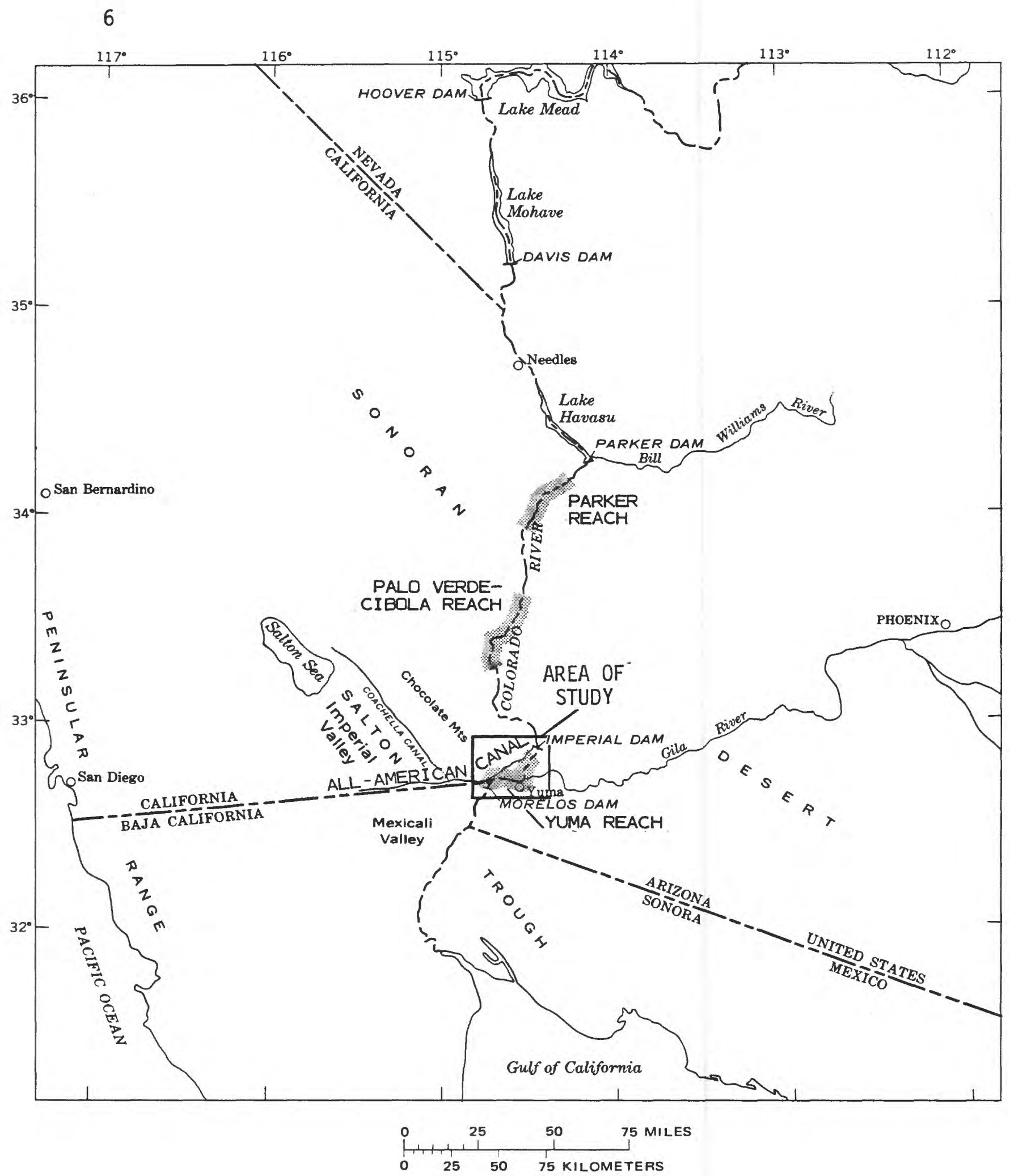

Figure 1.--Area of study. 
River in the Yuma reach (fig. 1). The method presented in this report was developed specifically for application in the Yuma area. The validity of the assumptions inherent in the method was evaluated on the basis of the local hydrologic system. The applicability of the method to other hydrologic systems is not addressed in this report.

\section{Acknowledgments}

The expertise of W. E. Moffitt, geologist, formerly of the U.S. Bureau of Reclamation, was greatly appreciated. His efforts contributed to the development of techniques for installing the piezometers. $\mathrm{He}$ also coordinated the test-drilling, construction, and maintenance responsibilities of the U.S. Bureau of Reclamation. E. E. Burnett, geologist, U.S. Bureau of Reclamation, worked many hours in obtaining geophysical and geologists' logs for about 70 test holes in the Yuma area.

D. W. Wilkins, hydrologist, U.S. Geological Survey, was the principal assistant on the project until early 1977. He helped develop instrumentation and operational procedures that were peculiar to the project. He was involved in the construction and operation of the electrical-analog models that were used in the early stages of the study and in the design and adaptation of the digital models that were used later.

\section{METHOD}

Return-flow estimates in the Yuma area are made by hydraulic analyses of ground-water flow in regions adjacent to the river at 18 cross sections spaced about $1 \mathrm{mi}$ apart (fig. 2). The hydraulic-analysis method involves computing return-flow rates at each cross section using average annual gradients to the river and estimated aquifer characteristics. The return-flow rates are applied to each subreach represented by a cross section. The computed return-flow estimates for the subreaches are summed for the entire Yuma reach.

The gradients to the river were determined from heads in the river and the aquifer. The heads in the aquifer were measured in 216 piezometers, 12 at each cross section, open to the aquifer at various depths below the, water table. About 40 digital recorders were used to record the heads.

Aquifer characteristics were estimated mainly from the evaluation of the response of the aquifer at each cross section to changes in river stage. Information from geophysical and geologists' logs at the piezometer locations and soil-moisture profiles from about 60 neutronprobe access tubes also were used. 


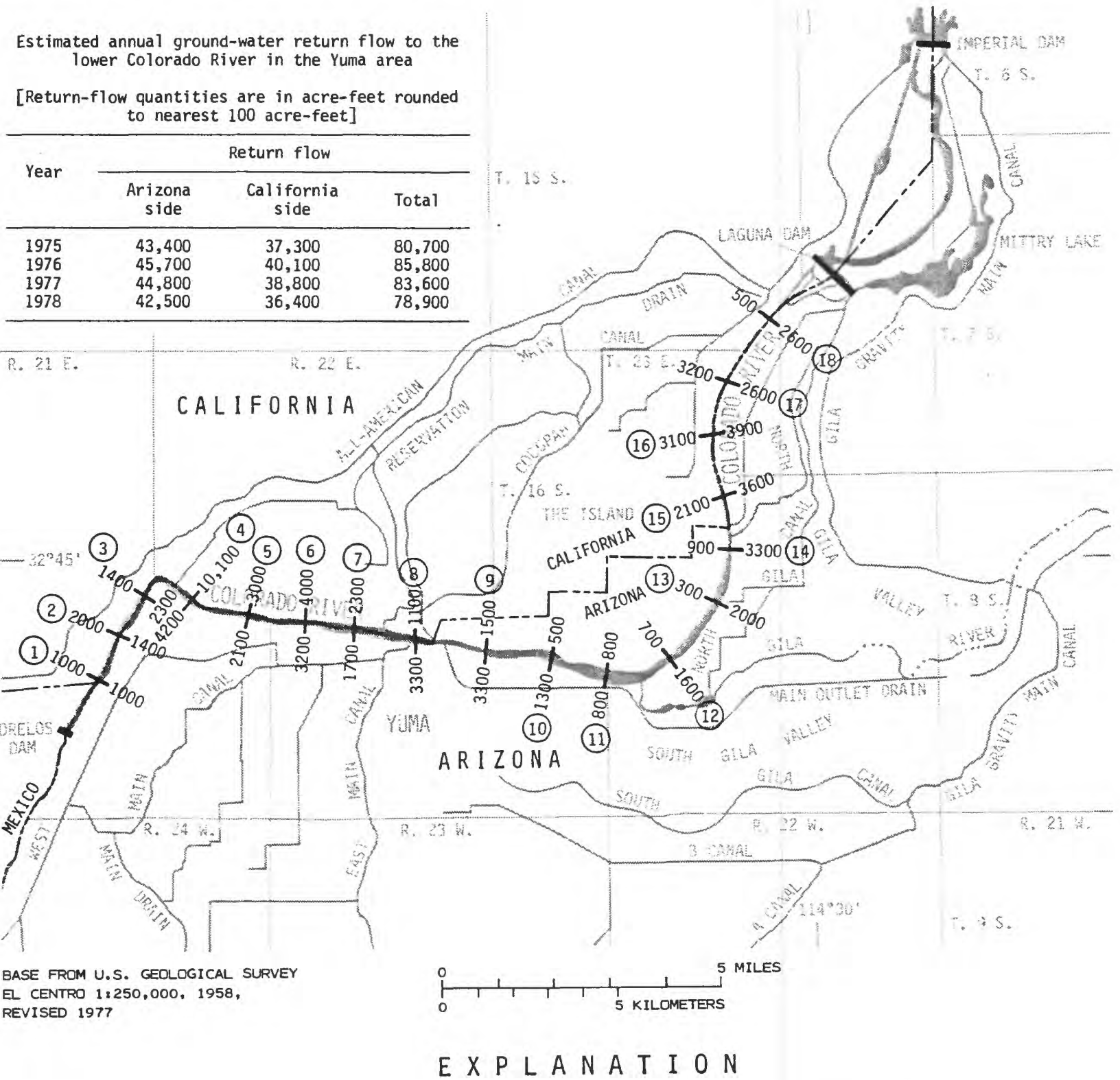

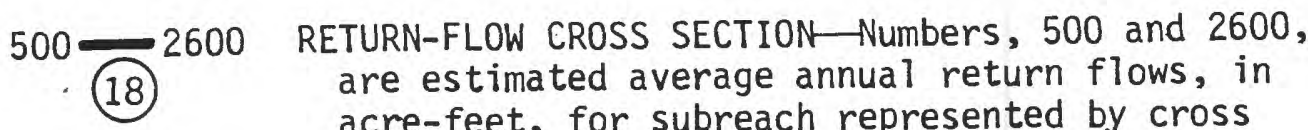
acre-feet, for subreach represented by cross section for 1975-78. Number, 18, is crosssection number

Figure 2.--Estimated ground-water return flows to the lower Colorado River in the Yuma area. 
The hydraulic analysis of the ground-water flow system was done using mathematical flow models run on digital computers. The mathematical models were used to estimate aquifer characteristics and to compute ground-water return flow from each side of the river.

RESULTS

Estimated annual return flows for 1975-78 are shown in figure 2. The average annual return flow for 1975-78 was estimated to be 44,000 acre-ft from lands on the Arizona side of the river and 38,000 acre-ft from lands on the California side. In this report, Arizona and California sides of the river, respectively, refer to the left and right sides of the river facing downstream even though the right side of the river includes land in both States. Although the reliability of the estimated return flows for the reach cannot be objectively determined, the total return flow for the reach estimated by the hydraulic-analysis method is in agreement with estimates made by other methods. The other methods, however, cannot be used to determine the side of the river from which the return flow originates. For comparison, ground-water return flows were computed with surface-water budgets for the Yuma reach. In the surface-water budgets, ground-water return flows to the river are estimated as the differences between known outflows and inflows to the river reach. Additionally, the U.S. Bureau of Reclamation has used salinity budgets to estimate ground-water return flows for the reach from Imperial Dam to the northerly international boundary near cross section 1 (E. E. Burnett, U.S. Bureau of Reclamation, written commun., 1981). The estimates made by the hydraulic-analysis method, the surface-waterbudget method, and the salinity-budget method are shown in figure 3 .

The results of the hydraulic-analysis method are estimates of the annual return-flow quantities rather than measurements. Groundwater return-flow quantities cannot be estimated to the same degree of accuracy that surface-water return-flow quantities can be measured. The accuracy or reliability of the estimated ground-water return-flow quantities cannot be assessed in this case; however, return-flow quantities for the entire Yuma reach are probably more accurate than those estimated for individual cross sections. A major advantage of the hydraulic-analysis method over the water-budget and salinity-budget methods is that estimates can be made of the amount of return flow entering the river from each side.

\section{FUTURE DECISIONS}

Collection of data may be the major expense associated with making future return-flow estimates using the hydraulic-analysis method. The data-collection costs will be related to the amount of data needed to satisfactorily estimate ground-water return flows. A preliminary study of data needs indicates that future computations of average annual heads and 


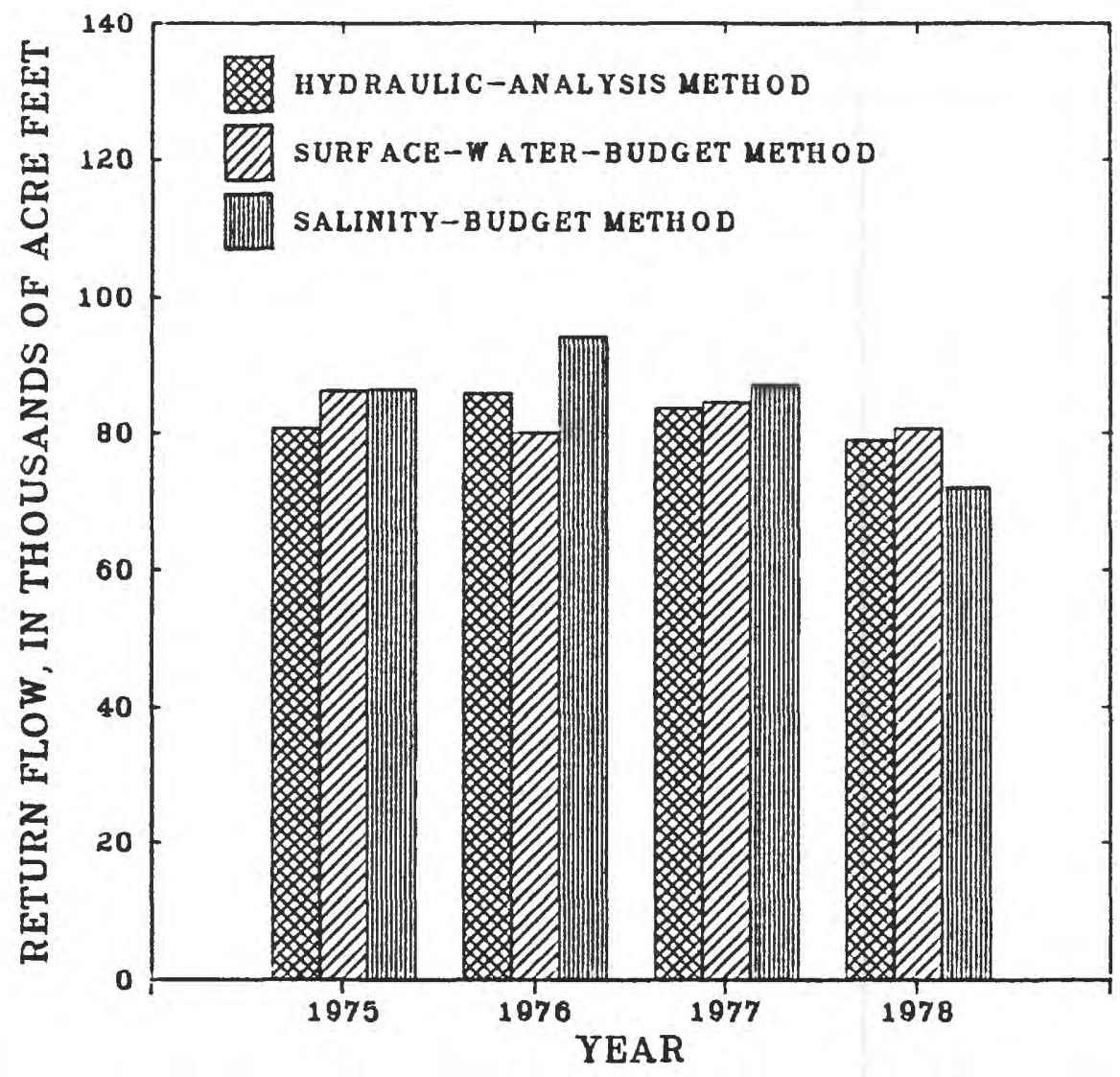

Figure 3.--Comparison of estimated annual return flows in the Yuma reach, 1975-78.

gradients will require fewer data than were needed for the development of the method. The study points out the need to evaluate the costs and the return-flow estimation errors associated with various levels of data collection. With this information, a decision can be made regarding the proper level of data collection.

Future estimates of return-flow quantities can be made with the hydraulic-analysis method using the existing data-collection network and the mathematical models provided that the hydrologic regimen of the area is similar to that of $1975-78$. Future conditions that might cause problems with the method or necessitate further analysis prior to application of the method are (1) increased ground-water pumping near the cross sections, (2) high river stages that inundate land around the piezometers, and (3) channelization of the Colorado River that causes significant changes in the river-surface elevations along the Yuma reach. Any future application of the method, therefore, should include an evaluation of changes of the hydrologic regimen in the Yuma area. If and when such conditions occur to the extent that the hydraulic-analysis method cannot provide reliable return-flow estimates, alternate methods must be used. 


$$
\begin{gathered}
11 \\
\text { paye } 13 \text { follows }
\end{gathered}
$$

PART II - TECHNICAL DISCUSSION 
HYDROLOGIC SETTING

The Colorado River in the Yuma reach is in hydraulic connection with the alluvial aquifer that underlies the river and adjacent flood plain. Water from upstream diversions recharges the alluvial aquifer as canal seepage and excess applied irrigation. Water returns to the river as ground-water seepage and as surface-water flow in drainage ditches.

\section{The Colorado River and Adjacent Land}

Most of the flow in the Colorado River at Imperial Dam is diverted to the All-American Canal or to the Gila Main Canal (fig. 4). Further diversion is made at Laguna Dam; consequently, the flow that enters the northernmost part of the study reach generally is only a few hundred cubic feet per second. This small amount of flow is conveyed in a dredged prismoidal channel about $130 \mathrm{ft}$ wide for about $5 \mathrm{mi}$ after which it flows into the natural channel of the river.

The natural channel generally is between 8 and $12 \mathrm{ft}$ below the adjacent flood plain and between 400 and $500 \mathrm{ft}$ wide. Only a part of the natural channel width is covered with water during normal flows. Islands of shifting sand and low-lying strips of land covered with riparian vegetation are common. About $3 \mathrm{mi}$ downstream from the dredged reach, the river changes direction from southward to westward; it maintains this course for about $11 \mathrm{mi}$ and then at the west edge of the flood plain turns abruptly south-southwestward toward the Gulf of California. Except in the dredged reach, a stage of $2 \mathrm{ft}$ or more above normal stage will cause the river to occupy the entire width of the natural channel.

Much of the flood plain is cropland irrigated with water from the Colorado River (fig. 4). In the Island area, however, about half of the land is cropland irrigated with ground water and river water. The irrigated areas commonly extend to within a few hundred feet of the natural channel. The area between the irrigated fields and the channel generally is occupied by phreatophytes or weeds, depending largely on the depth to water.

\section{Geology}

The geology of the Yuma area is discussed in detail by Olmsted and others (1973). The geologic units with which this study is concerned were classified as older alluvium and younger alluvium. The older alluvium comprises many varieties of material ranging from clay to cobble and boulder gravel. The greatest bulk of the older alluvium is deposits of the old Colorado and Gila Rivers and consists of well-sorted sand and lesser amounts of silt and clay. The gravel includes well-rounded pebbles and cobbles. 


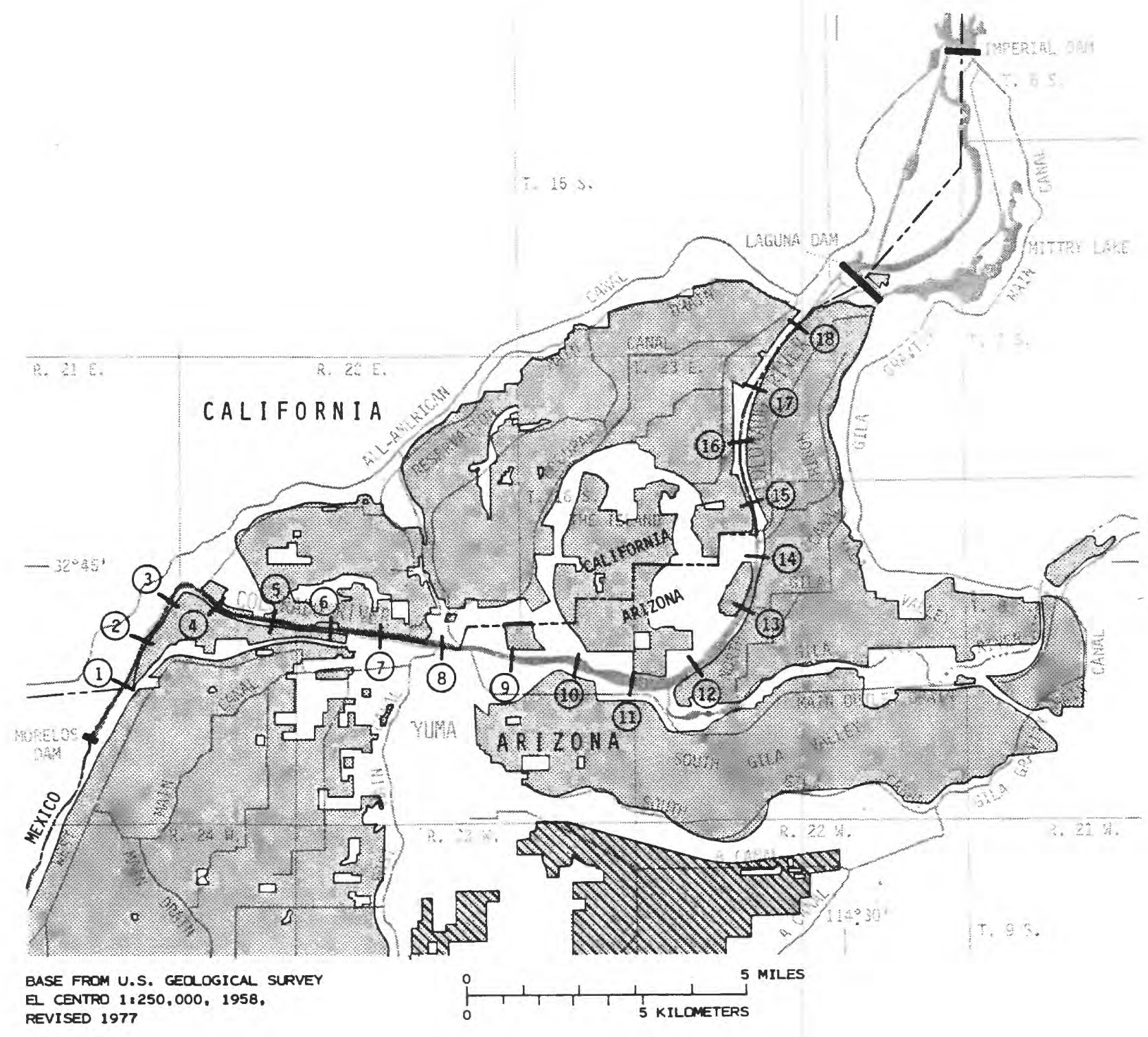

Figure 4.--Cropland in the Yuma area, 1978. 


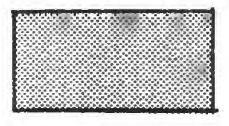

CROPLAND IN THE FLOOD PLAINS OF THE COLORADO AND GILA RIVERS-From U.S. Bureau of Reclamation (1979)

CROPLAND ON MESA LAND-From U.S. Bureau of Reclamation (1979)

RETURN-FLOW CROSS SECTION-Number, 10 , is cross-

(10) section number 
The younger alluvium that was investigated in this study consists of deposits laid down during the most recent cycle of deposition of the Colorado and Gila Rivers. It consists mostly of sand and silt to a depth of about $100 \mathrm{ft}$ below the flood plain. One extensive bed of silt and clay lies immediately beneath the flood plains of the Colorado and Gila Rivers. The bed has been replaced in some places by scour and fill of sand along channels occupied by the rivers during relatively recent times (Olmsted and others, 1973, p. 53). Beneath the bed of silt and clay is sand interspersed with clay layers, and in some areas a basal unit of well-rounded gravel is present. This basal unit, however, is not easily differentiated from the gravels of the upper part of the older alluvium that underlie much of the flood plain. (See Olmsted and others, 1973.)

For this study, the sand, silt, and clay layers of the younger alluvium are referred to as the upper fine-grained unit. The basal gravel of the younger alluvium and the gravels of the upper part of the older alluvium are referred to as the lower gravel unit. Material of the older alluvium other than the upper gravels are referred to as the older alluvial unit. The relation between the geologic units described by Olmsted and others (1973) and the geohydrologic units used in this report is given in the following table:

Geologic classification by Olmsted and others (1973)

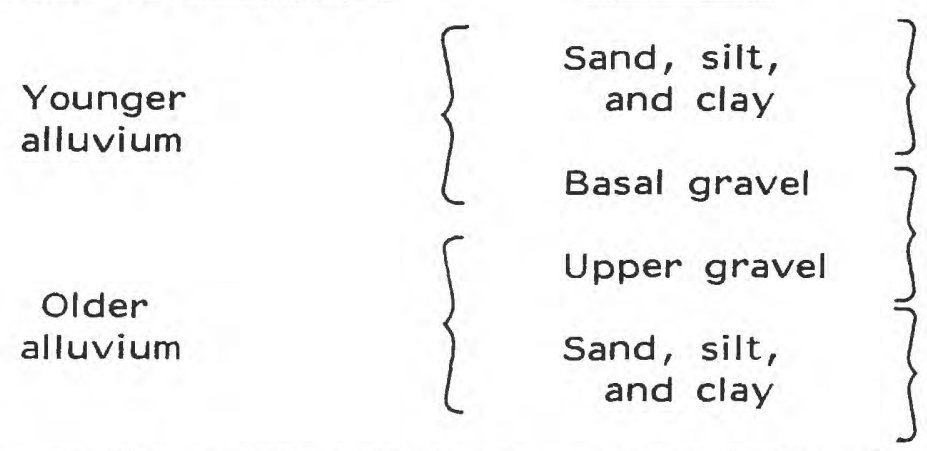

Geohydrologic units used in this report

Upper fine-grained unit

Lower gravel unit

Older alluvial unit

Because of the method that was selected for determining return flows, this study is concerned only with the hydraulic characteristics of the sediments generally within a half mile of the river and about $150 \mathrm{ft}$ deep or to the base of the lower gravel unit where present.

\section{Aquifer Characteristics}

The lower gravel unit includes the most permeable deposits in the Yuma area. The hydraulic conductivities of the lower gravel unit were estimated to be as great as $1,300 \mathrm{ft} / \mathrm{d}$ and to average about $650 \mathrm{ft} / \mathrm{d}$. Moderately to fairly permeable deposits comprise much of the upper fine-grained unit. The average hydraulic conductivities for the upper fine-grained unit were estimated to be $70 \mathrm{ft} / \mathrm{d}$, although the range may vary from a few tens to several hundreds of feet per day. Poorly permeable deposits that consist of the clay and silt strata are found in 
the upper fine-grained unit and the older alluvial unit. An earlier study (Olmsted and others, 1973, p. 69) indicated that the average thickness of the clay and silt strata in the top $100 \mathrm{ft}$ beneath the river valleys is about $15 \mathrm{ft}$, although the range is from 0 to more than $50 \mathrm{ft}$. The clay strata are thickest in the South Gila Valley. Most of the clay strata contain sand and silt; thus the strata are poorly permeable rather than impermeable.

The most significant hydraulic effect of the clay and silt strata is that vertical movement of water is restricted. At some locations several miles north of the mouth of the Gila River and $100 \mathrm{ft}$ from the river, head differences of several feet were observed in piezometers that tap deposits immediately above and below clay strata. In contrast, at locations without the presence of continuous clay strata, head differences of several hundredths or several tenths of a foot were observed in piezometers open to the aquifer at various depths $100 \mathrm{ft}$ from the river. Vertical movement of water is also restricted-by layering of the sediments.

Most of the ground water along the reach of the river is unconfined. In much of the area, however, silty or clayey layers near the water table result in delays in storing or releasing water from storage during water-table fluctuations. The effects of delayed yield were substantial and prevalent and therefore could not be ignored in investigating the hydraulic properties of the material in which return flow to the river was occurring. Delayed-yield capability, therefore, was incorporated in the ground-water flow models used to analyze cause-and-effect relations of head change and time.

\section{Ground-Water Movement}

Before agricultural development in the area, the ground water in the alluvium was recharged by the Colorado and Gila Rivers. The movement of ground water generally was in a downvalley direction, and ground water flowed southward and westward from the area (Olmsted and others, 1973, p. 84; figs. 27, 28). Some water was discharged from the aquifer through evapotranspiration by native vegetation in the flood plains of the Colorado and Gila Rivers.

The configuration of the water table in 1978 (fig. 5) indicates that water flows toward the Colorado River from various sources of recharge including the Gila Main Canal, the All-American Canal, and irrigated cropland in the Colorado and Gila River flood plains and on the Yuma Mesa. Ground-water recharge and withdrawal by many canals, drains, and wells also affect the direction of ground-water movement.

The conversion of the Colorado River from a source of ground-water recharge to a drain was brought about by several factors. An obvious factor contributing to ground-water flow toward the Colorado River is water-level rises from recharge associated with agricultural development. Other factors relate to river regulation and diversions upstream in the drainage basins. The construction of dams on the 


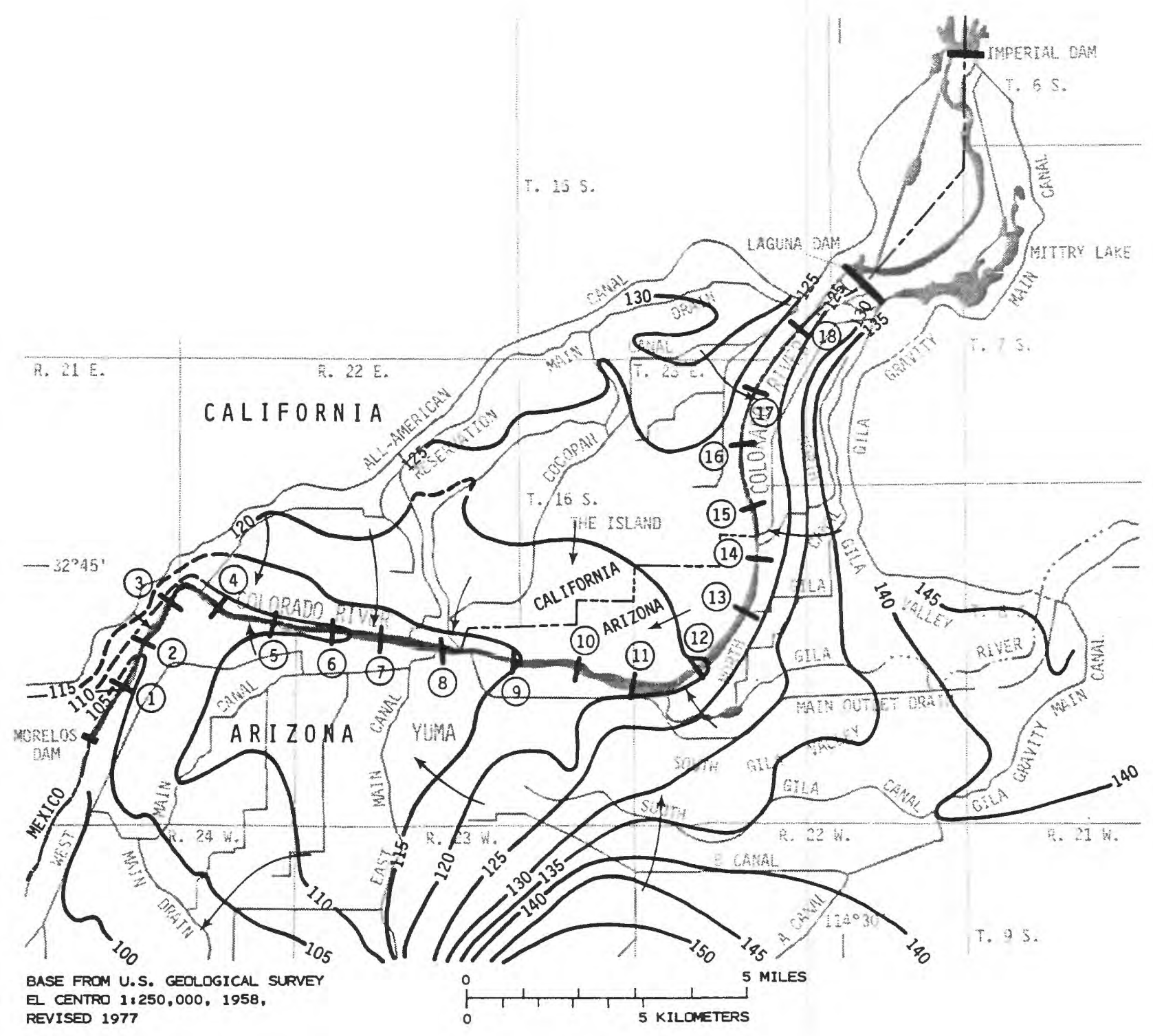

Figure 5.--Water-table configuration in the Yuma area, December 1978. 
EXPLANATION

19

120- - WATER-TABLE CONTOUR -Modified from U.S. Bureau of Reclamation (1979). Shows approximate altitude of the water table, December 1978. Dashed where inferred. Contour interval 5 feet. National Geodetic Vertical Datum of 1929

GENERALIZED DIRECTION OF GROUNDWATER FLOW

10

RETURN-FLOW CROSS SECTION -Number, 10, is crosssection number

Figure 5 
Colorado River reduced the sediment load in the Yuma reach, which caused degradation of the river channel. Diversions upstream from the Yuma reach have almost eliminated the flow of the Gila River at the mouth and greatly reduced the flow in the Colorado River below Imperial Dam. The reduced flows in the Colorado River and the degradation of the river channel have lowered the average annual river stage at Yuma between 5 and $10 \mathrm{ft}$ since the completion of Hoover Dam in 1935. The lower river stage and the effects of recharge from agriculture have made the Colorado River a significant drain in the ground-water system in the Yuma area.

Under the prevailing ground-water flow regimen, possible sources of ground-water discharge to the river are recharge from agricultural development, natural recharge, and release of water from storage in the aquifer. Natural recharge in the Yuma area generally is insignificant in comparison to recharge from agricultural development because average annual rainfall in the Yuma area is less than 3 in. (Sellers and Hill, 1974, p. 588-591). Some natural recharge may occur from infiltration of flow in the Gila River during infrequent periods of runoff from upstream areas. For the purposes of this study, however, natural recharge can be considered to be insignificant. Release of water from storage may be significant during and immediately after periods when the river stages are dropping. At present (1982), however, long-term lowering of river stages is not known to be occurring. For periods when the river stages in the reach vary in a cyclical manner, ground-water storage as a source of discharge to the river is negligible. For such periods, recharge from agricultural development is the only significant source of ground-water discharge to the river. Ground-water discharge to the river therefore can be considered as ground-water return flow from agricultural development.

\section{METHOD}

The method selected for estimating ground-water return flow in the Yuma area involves computation of flow components on the basis of principles of ground-water hydraulics and the physical and hydraulic characteristics of the alluvial aquifer. One possible approach to the hydraulic analysis is to consider three-dimensional flow components in the aquifer system that underlies the flood plain and adjacent mesas. These flow components can be simulated with mathematical models. A problem with this approach is that many components of flow in the hydrologic system cannot be reliably quantified. These components include infiltration of canal seepage and irrigation water, evapotranspiration, and ground-water outflow from the area. Some of these quantities are much larger than the ground-water return-flow quantity. Because of the potential for large errors in estimating these flow components, the analyses of ground-water flow components were restricted to a relatively narrow part of the aquifer on each side of the river.

The hydraulic-analysis method as applied for estimating ground-water return flow in the Yuma area involves the computation of components of flow normal to the river at cross sections of unit river length (fig. 6). Flow components were computed at 18 cross sections 


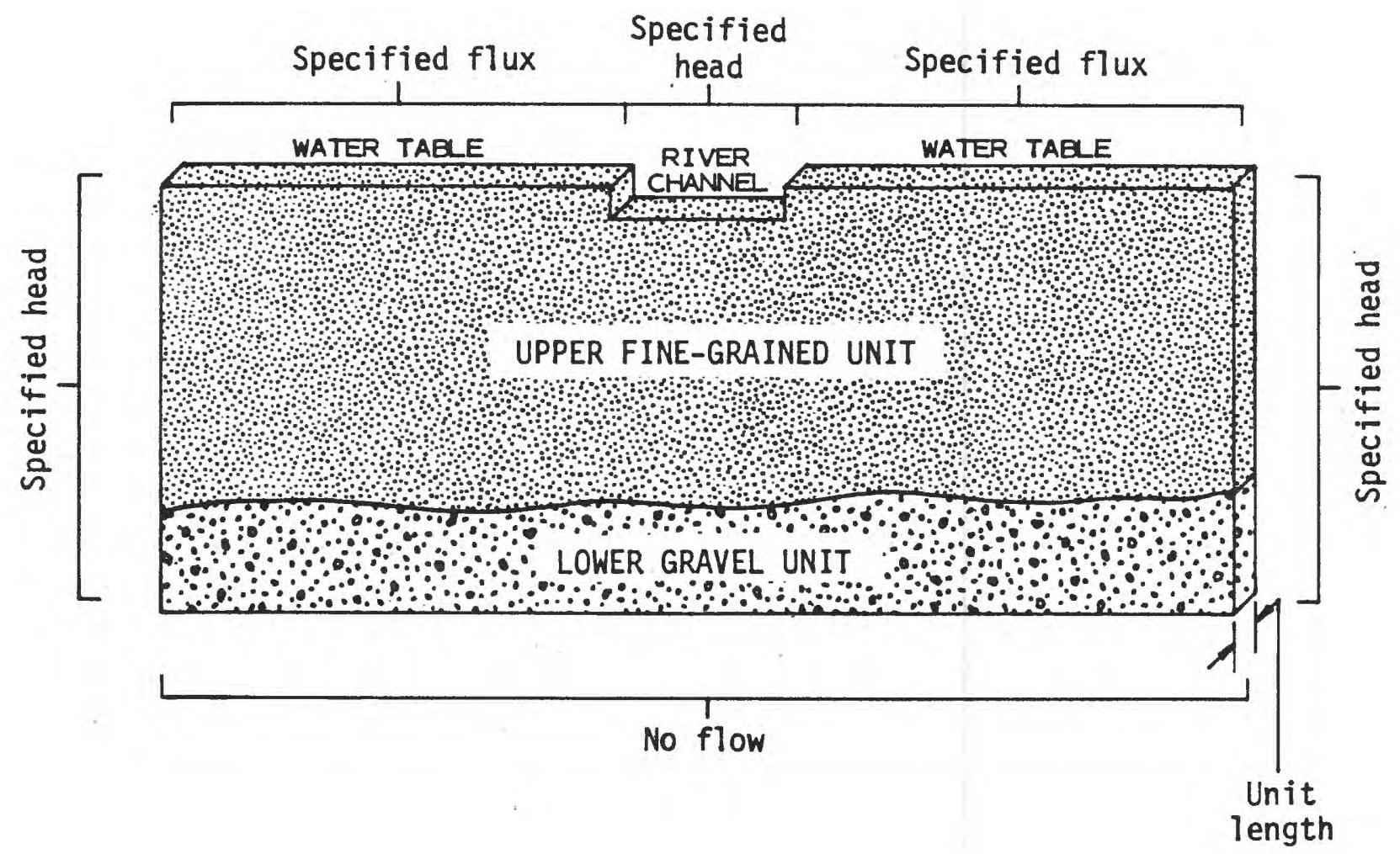

Figure 6.--Typical cross section with steady-state boundary conditions used in the hydraulic-analysis method. 
spaced at approximate 1-mile intervals over the Yuma reach (fig. 2). The inflow per unit length of river computed at each cross section was applied to the subreach that extends from the cross section to points midway between upstream and downstream cross sections. At the end cross sections, the subreach extends from the cross section to the point midway to the adjacent cross section. The simulated flow quantities entering the river from each side are the estimated return-flow quantities for a subreach. Return-flow quantities for individual subreaches were summed to obtain an estimate of return flow for the entire Yuma reach.

The cross sections are normal to the river and generally extend to about $500 \mathrm{ft}$ beyond the river on each side; thus the cross sections include little irrigated land. Deep percolation to the water table therefore is of minimal importance in the hydraulic computations. The saturated part of the upper fine-grained unit and the lower gravel unit are represented by the cross sections.

The computed amounts of ground-water inflow to the river per unit length of river at the cross sections are discrete approximations of the inflow along the Yuma reach. Inflow is continuously distributed along the reach and varies with spatial changes in the physical and hydraulic characteristics of the aquifer and the hydraulic gradient of the ground water. The total computed inflow for the Yuma reach is the sum of the products of the flow per unit length and the length of reach for each of the 18 cross sections.

The use of discrete samples of inflow from a continuous distribution is a concept that is commonly used in statistical sampling. The computations of inflow at each cross section were based on measured and estimated characteristics at each cross section. The computed amounts of inflow for the subreaches therefore are considered to be virtually independent. In the summation of inflows for the subreaches, the errors are partially compensating. The probable error of the total inflow to the Yuma reach may be expressed mathematically as the square root of the sum of the squares of the individual errors for each subreach. For an analogous discussion of probable errors, see Carter and Anderson (1963). The estimate of total inflow computed as the summation of the inflow for the 18 subreaches therefore is likely to have a much smaller error in percent of total inflow than the estimates for individual subreaches.

The mathematical equation describing three-dimensional steadystate ground-water flow in an aquifer that is isotropic in the horizontal plane may be expressed as

$$
\frac{\partial}{\partial x}\left(K_{h} \frac{\partial h}{\partial x}\right)+\frac{\partial}{\partial y}\left(K_{h} \frac{\partial h}{\partial y}\right)+\frac{\partial}{\partial z}\left(K_{v} \frac{\partial h}{\partial z}\right)=0,
$$


where

$$
\begin{aligned}
x & =\text { horizontal distance normal to the river, } \\
y & =\text { horizontal distance parallel to the river, } \\
z & =\text { vertical distance, } \\
K_{h}, K_{v}= & \text { horizontal and vertical hydraulic conductivity, } \\
& \text { respectively, and } \\
h= & \text { head. }
\end{aligned}
$$

If the rate of change of the flow component in $y$ direction is small and can be neglected, the second term in equation 1 can be dropped. Equation 1 then reduces to

$$
\frac{\partial}{\partial x}\left(K_{h} \frac{\partial h}{\partial x}\right)+\frac{\partial}{\partial z}\left(K_{v} \frac{\partial h}{\partial z}\right)=0
$$

which is used in the hydraulic-analysis method to estimate the return flow in the Yuma reach. The validity of applying equation 2 was tested by comparing rates of change of head gradient parallel and normal to the river estimated from observed average head values for 1974-78. The rates of change of head gradient parallel to the Colorado River are two to four orders of magnitude smaller than those normal to the river. This comparison is evidence that flow components parallel to the river can be neglected in the computation of flow components normal to the river. The application of equation 2, however, may result in some errors for individual cross sections if local variations in hydraulic conductivity occur or the river course angles sharply with the local flow direction. For the entire reach or over large subreaches, the net change in the flow component parallel to the river probably is insignificant.

Equation 2 describes steady-state ground-water flow. Under certain conditions, this equation can be applied to describe the time average of transient flow over a given period. Conditions necessary for this application are (1) head changes that occur within the period do not significantly change the transmissive properties of the aquifer and (2) the water-table configuration at the beginning and end of the period are approximately the same. By selecting a 1-year period for time averaging, these conditions are satisfied in the Yuma area. Changes in the saturated thickness of the aquifer within a 1-year period are generally much smaller than the average saturated thickness. Additionally, the changes generally occur in silty sediments that are less permeable than underlying sediments in the aquifer. Head changes therefore have little effect on the transmissive properties of the aquifer. The water-table configurations are approximately the same at 1-year intervals because the seasonal nature of irrigation practices results in river and ground-water heads that generally follow a 1-year cycle. Resulting changes in ground-water storage therefore are small. In applying equation 2 to average transient flow, values of head and flow are average values for the 1-year period. 
To solve equation 2 at a cross section, values of $K_{h}$ and $K_{v}$ must be known at all points and values of head or flux must be known at all boundaries and all points within the cross section. Flux, as used in this report, is the volumetric rate of flow per unit area entering or leaving the cross section. The boundary conditions used were specified head, specified flux, and no flow (fig. 6). Additionally, the simplifying assumption was made that the parts of the upper boundary corresponding to the water table could be represented as being horizontal at a fixed elevation. The specified-head boundary corresponding to the river was represented as being in direct hydraulic connection with the adjacent aquifer without restriction of flow caused by fine-grained river-bed sediments. This representation is reasonable because thick, extensive, fine-grained river-bed sediments are not likely to be present in the Yuma reach of the Colorado River. The lower boundary was treated as a no-flow boundary because the lower gravel unit, where present, generally is a highly transmissive layer that allows the water to move laterally toward the river. The hydraulic conductivity of the underlying older alluvial unit generally is much less than that of the lower gravel unit. Because of this contrast in hydraulic conductivity, the lower gravel unit probably does not transmit significant quantities of water from irrigated land to the river. The flow quantities entering the cross section across the lower boundary therefore are assumed to be negligible in comparison to the flow quantities entering across the lateral boundaries.

To solve equation 2 for heads and flow components, the information needed for each cross section is (1) physical dimensions, (2) average annual head in the river, (3) average annual heads at the lateral boundaries, (4) distribution of vertical and horizontal hydraulic conductivities, and (5) flux normal to the water table. Physical dimensions of cross sections were determined from well logs and transit-stadia surveys. Reasonable estimates of head were obtained by monitoring ground-water and river heads at the cross sections. Obtaining estimates of the hydraulic conductivities, however, required a more involved procedure. This procedure was to simulate the transient response of the aquifer to a changing river stage at each cross section. The response of the aquifer to a changing river stage is a function of the hydraulic conductivity and storage characteristics of the aquifer. In order to use transient-flow models to estimate hydraulic conductivity, therefore, it was necessary to estimate the specific yield of the aquifer. Specific yield was estimated using data from soil-moisture profiles. (See section entitled "Specific Yields.") The flux normal to the water table was initially estimated using infiltration and evapotranspiration rates thought to be typical for the area. The results of the method were later determined to be insensitive to this flux because it is much smaller than the flow normal to the river within the bounds of the cross sections.

\section{Data Collection and Processing}

Data collected for the study included ground-water heads and river stages for the determination of average annual gradients and aquifer 
response to stresses. Soil-moisture data for estimation of specific yields also were collected.

\author{
Ground-Water Head
}

Ground-water head was measured in piezometers, or smalldiameter wells, installed at 12 sampling points within each cross section. The sampling points generally were in the upper fine-grained unit or in the upper part of the lower gravel unit at depths near the contact between the units, near the midpoint, and just below the water table in the upper fine-grained unit. The points were about $100 \mathrm{ft}$ from the river and at some farther distance, commonly 400 to $600 \mathrm{ft}$ from the river. The piezometers $100 \mathrm{ft}$ from the river on each side are referred to as nearcluster piezometers, and those 400 to $600 \mathrm{ft}$ from the river on each side are referred to as far-cluster piezometers. Each piezometer within a cross section is referenced with $A Z$ or $C A$ followed by a single digit from 1 to 6. $A Z$ indicates that the sampling point is on the Arizona side of the river. Similarly, CA indicates that the sampling point is on the California side of the river although not necessarily within the State of California. The digits 1,2 , and 3 indicate the shallow, medium, and deep locations, respectively, about $100 \mathrm{ft}$ from the river. The digits 4 , 5 , and 6 indicate the shallow, medium, and deep locations, respectively, about 400 to $600 \mathrm{ft}$ from the river. For example, CA4 indicates a shallow sampling point in the far cluster on the California side of the river.

Shallow piezometers were commonly installed by jetting the screen and pipe to the desired depth. Medium-depth and deep piezometers were usually installed by drilling to within about $5 \mathrm{ft}$ of the desired depth with a direct rotary drilling rig and jetting the screen and pipe to the desired depth. A thick bentonite slurry was injected into the annulus above the well screen to prevent vertical movement of water within the drill hole. After completion, the piezometers were slug tested to insure that they were responsive to head changes in the aquifer.

Typically, the piezometers consisted of a 2-foot-long stainless steel well screen attached to sufficient length of $1 \frac{1}{2}$-inch-diameter galvanized pipe to bring the top to as shallow a depth as would insure that it would always be below the water table. Atop this was a 3-inch-diameter galvanized pipe that extended a foot or more above the land surface.

A float in the 3-inch diameter pipe turned a potentiometer. The position of the potentiometer was sensed by electronic circuitry in a programing unit and every 3 hours a value corresponding to the head in the piezometer was punched on a digital-recorder tape in sequence with values from five other piezometers. The punched tapes were collected monthly and processed by computer to convert the values to heads and compute time averages.

The instrumentation at a typical piezometer, a cluster of three piezometers, and a programing unit are shown in figures 7, 8, and 9, 


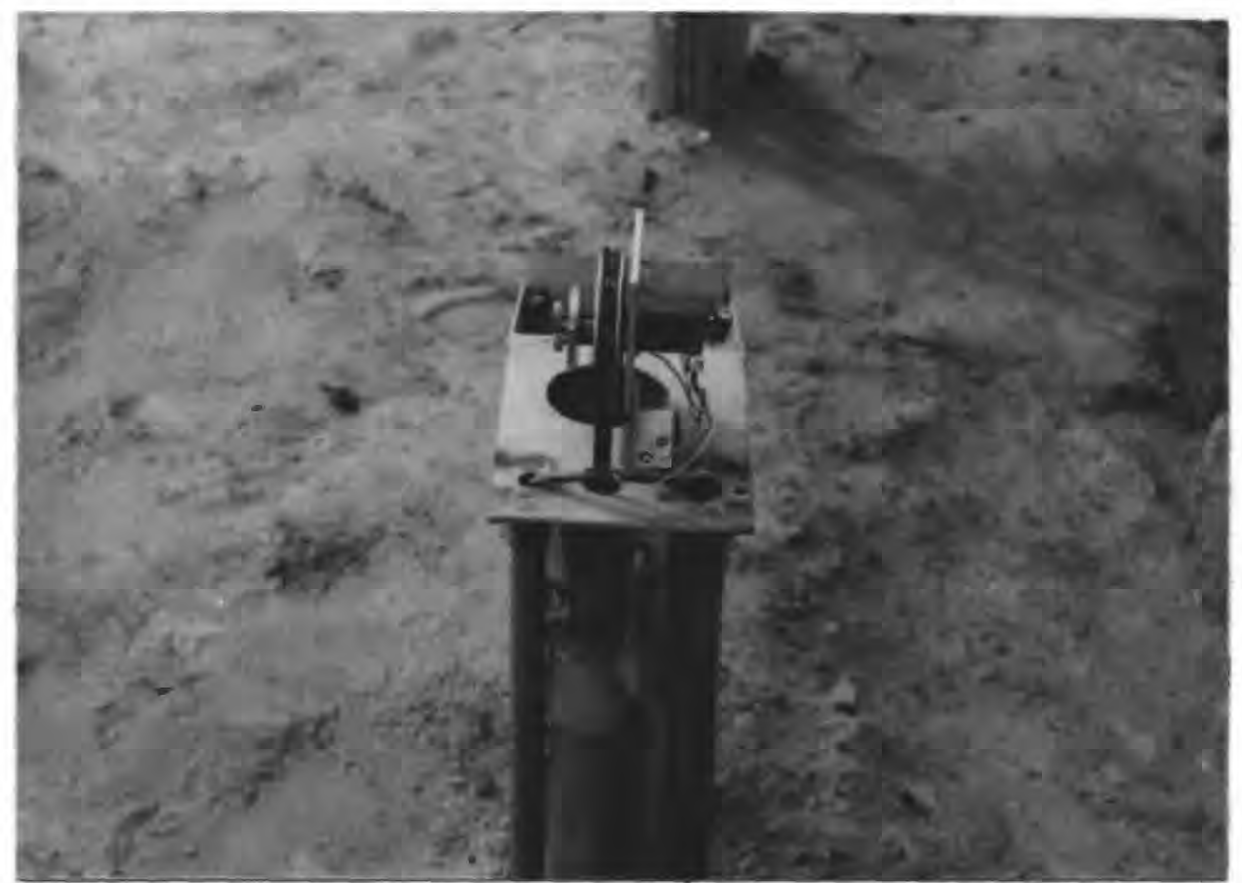

Figure 7.--Instrumentation at a piezometer site (hinged cover open). Note the 10-turn potentiometer to which is attached the splined float wheel and electrical wiring for transmitting voltage differences to the programing unit attached to a digital recorder several hundred feet distant. 


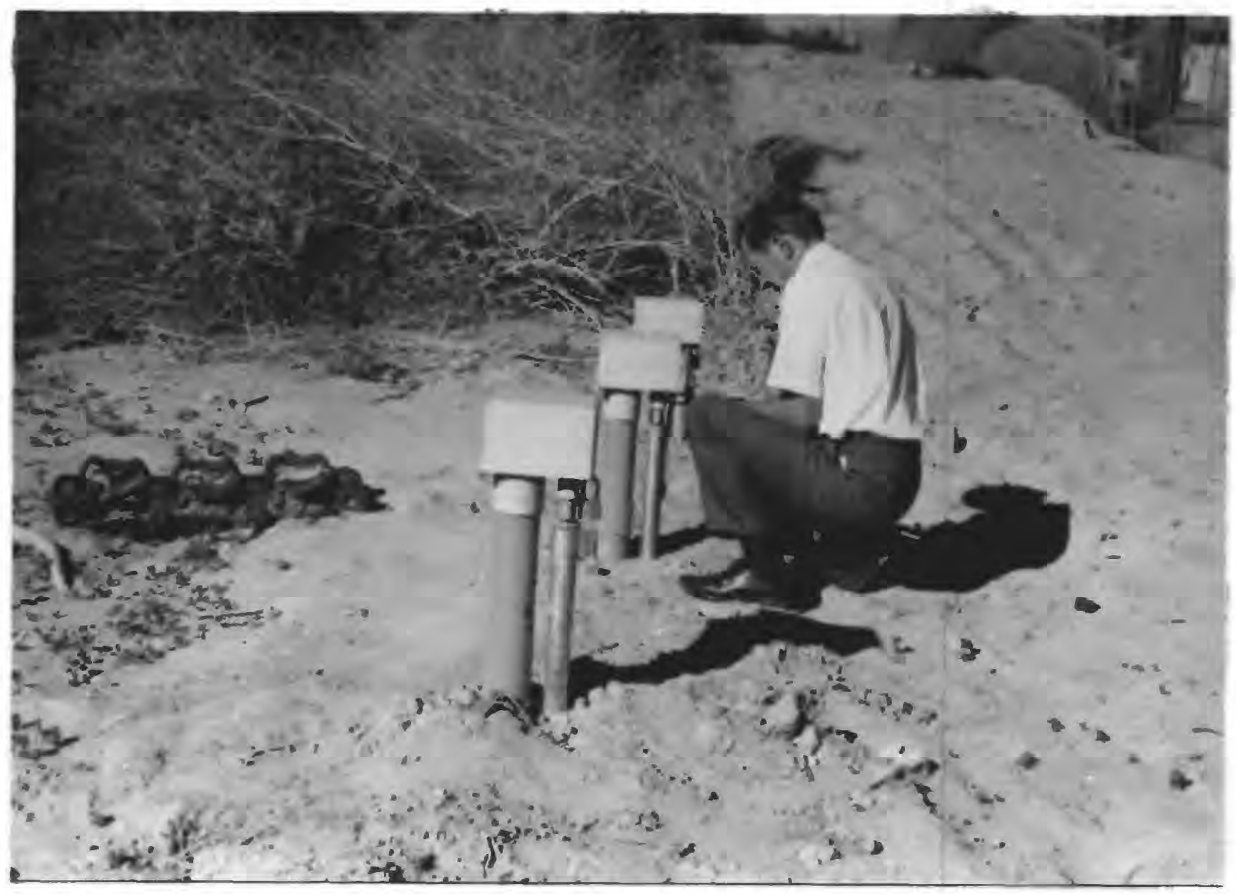

Figure 8.--Typical cluster of three piezometers. The site is 400 feet from the river; a similar cluster is 100 feet from the river, and the recorder is about midway between the cluster sites. The recorde: shelter (barely visible) is just above the upper left corner of the cleared strip. 


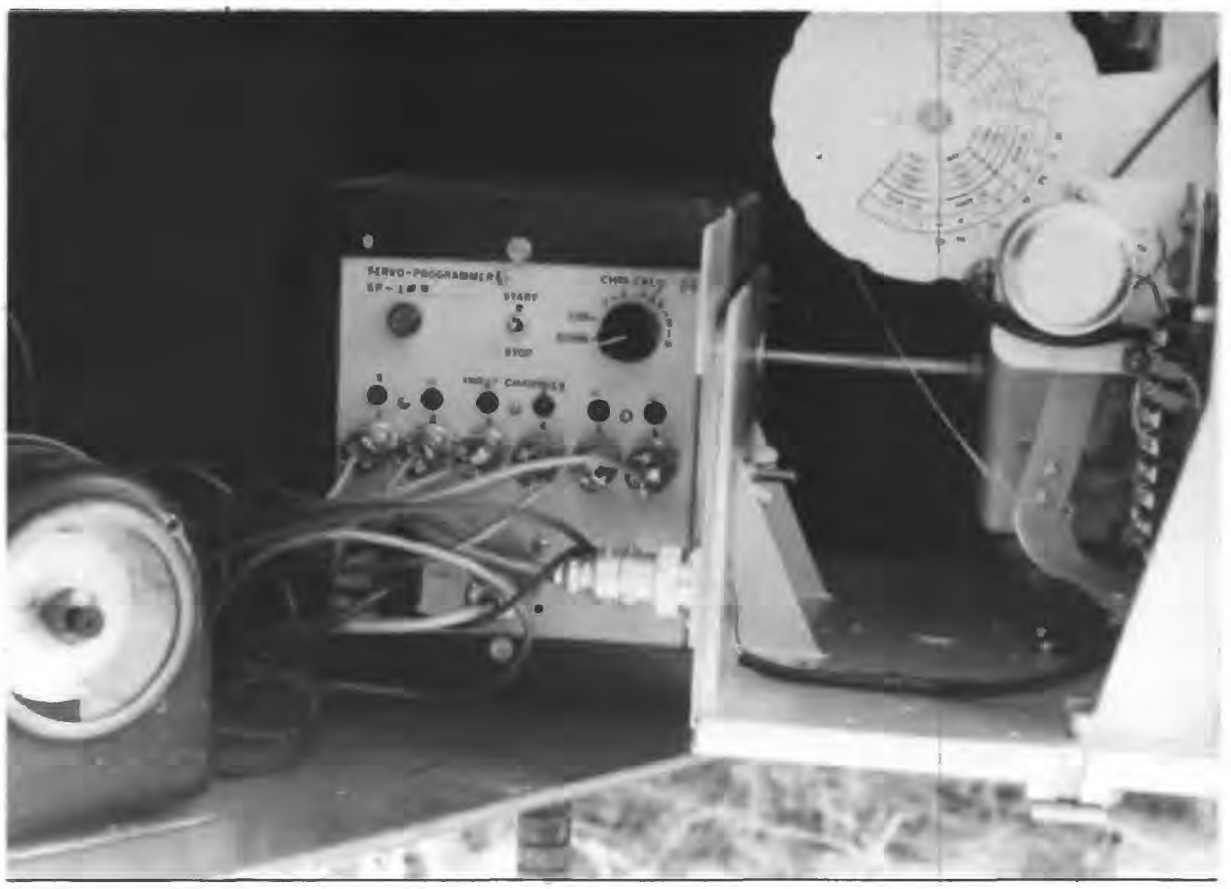

Figure 9.--Programing unit attached to rear of digital recorder. Note the six input channels and the channel-calibration switch near the upper right-hand corner of the face of the unit. 
respectively. The programing unit was designed and built for the project by U.S. Geological Survey personnel at national headquarters.

River Stages

River-stage stations were installed at 16 cross sections. Stations were not installed at cross sections 17 and 15 because it was thought that the rather uniform dimensions of the dredged channel would allow reliable estimation of river stage using data from the cross sections upstream and downstream.

A typical river-stage station is shown in figure 10. The instrumentation is similar to that used for the piezometers. The data were recorded at 3-hour intervals on the channel usually reserved for the medium-depth piezometer of one of the far clusters. This substitution was satisfactory because relations between heads in piezometers at the far clusters had been established prior to the substitution and any subsequent changes in relations could be ascertained from data obtained at the time of the monthly servicing of the equipment. Values corresponding to river stages were punched by the recorder on the digital tapes with the data from the piezometers. Time averages of the river stages were computed when the punched tapes were processed by a computer.

\section{Specific Yields}

Studies for obtaining information on specific yields consisted of analyzing soil-moisture (volumetric water content of soil) data collected at selected sites. Two steel access tubes in which a neutron probe could be lowered to a depth a few feet below the water table were installed about $5 \mathrm{ft}$ upstream and downstream from the shallow piezometer at 32 of the 36 near-cluster sites in the Yuma area.

The tubing had an inside diameter of $1.62 \mathrm{in.}$ and an outside diameter of $1.75 \mathrm{in.}$ It was advanced to the desired depth by alternately driving it with a maul and flushing the soil from inside the tubing. This procedure insured a tight fit between the tubing and the surrounding material. On completion of the driving operation, a combination of rubber stoppers was installed near the bottom of the tubing to make a watertight seal. Any free water inside the tubing was removed, and the top of the tubing was sealed with a removable rubber stopper. After sufficient time had elapsed so that the moisture profile near the tubing was no longer thought to have been changed because of the construction of the access hole, the site was considered ready for the soil-moisture studies.

The soil-moisture studies were made by lowering a neutron probe to the bottom of the tubing and observing the rate at which the detector picked up slow neutrons at selected depth intervals as the probe 


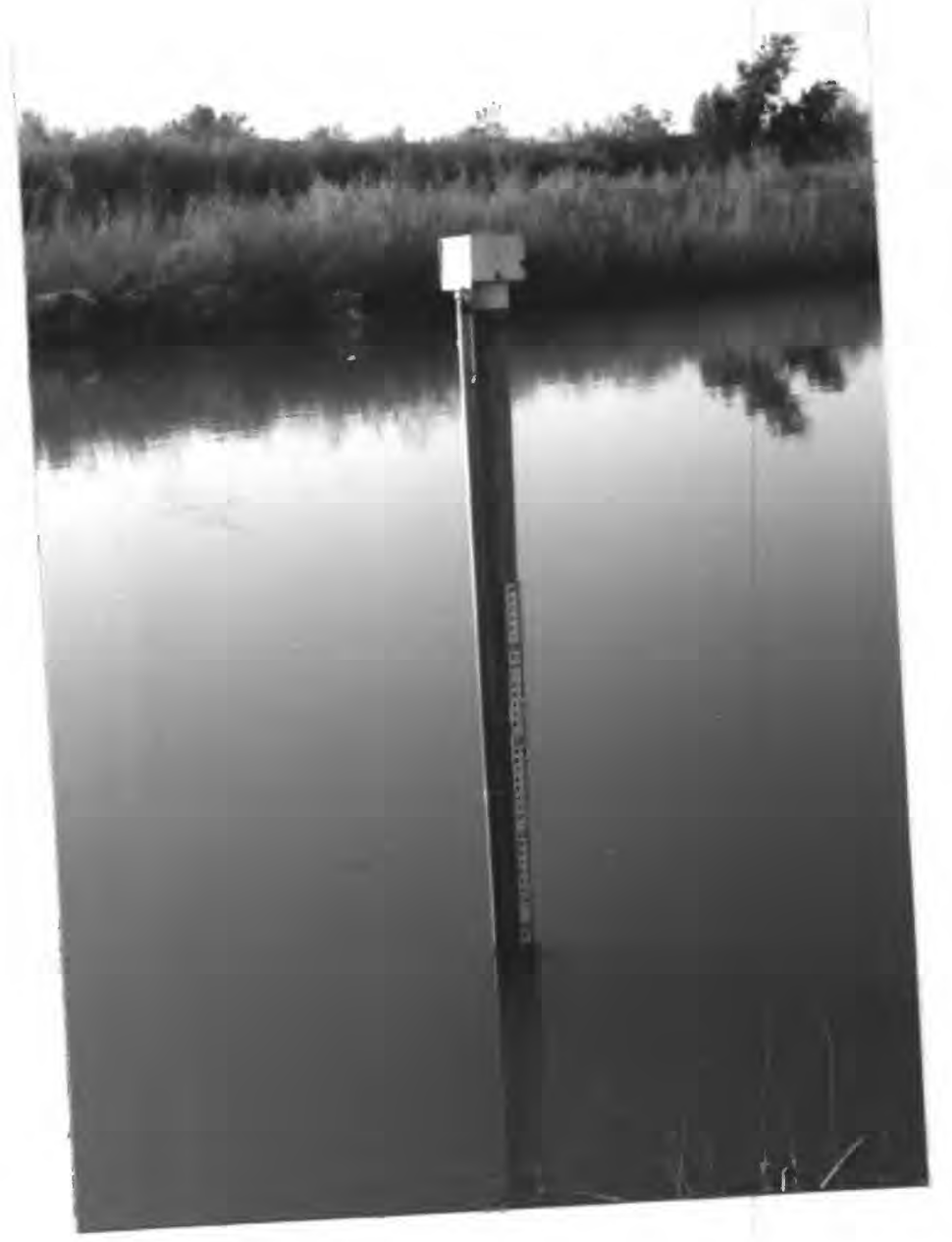

Typical river-stage station. A three-conductor cable transmits changes in the float-operated potentiometer inside the metal box at the top of the pipe to the programing unit of the digital recorder for the cross section. 
was raised. A comparison between these counting rates and the counting rates of calibration tests enabled an estimate to be made of the moisture content at each selected depth. Plotting the soil-moisture contents at the corresponding depths permitted the drawing of a soil-moisture profile for the material penetrated by the access tube. Soil-moisture profiles were obtained after a few weeks of fairly steady flow conditions and then during and near the end of a period of rising heads. These profiles provide reliable information on changes in soil moisture and on the storage characteristics (specific yield) of the material within the zone of water-table fluctuation.

Specific yield was determined from soil-moisture measurements made before and during a 48-hour release of $2,500 \mathrm{ft}^{3} / \mathrm{s}$ of water from Laguna Dam which the U.S. Bureau of Reclamation scheduled for August 14-17, 1973, at the request of the U.S. Geological Survey. Prior to the release, soil-moisture profiles were obtained for each access hole. Near the end of the release, soil-moisture profiles were obtained again. To estimate specific yields, the soil-moisture profiles at each access hole were compared to determine changes in moisture (fig. 11). The volume of water entering storage per unit aquifer-surface area was computed as the area between the soil-moisture curves at depths over which changes in soil moisture were judged to be the result of changes in head at the water table. This volume per unit aquifer-surface area was divided by the change in head in the adjacent shallow piezometer to obtain an estimate of the specific yield for the access hole.

Specific yields from the two access holes were averaged to obtain an estimate of specific yield for each near-cluster site. In general, the data obtained by following this procedure were useful for estimating specific yields except where the change in head in the shallow piezometer was too small or where the soil was saturated or nearly saturated to the land surface. At five sites where the neutron-probe method did not yield satisfactory results, data collected from comparable sites were used to estimate the specific yields.

The specific yields estimated for each cross section are shown in table 1. The values range from 0.13 to $0.28 ; 32$ of the 36 values are in the range of 0.15 to 0.23 . The average value is 0.19 , which is typical for unconfined aquifers (Lohman, 1979, P. 8).

\section{Models of the System}

Equation 2 can be solved approximately by using mathematical flow models. A finite-difference model program developed by Tresco't and others (1976) was used for solving equation 2 to simulate flow in each cross section. Each cross section was divided into rectangular blocks with a variable-spaced grid. Finite-difference approximations are made between the centers, or nodes, of blocks for the continuous derivatives in equation 2. The result is a system of linear equations that are solved for head distribution and flow components. A direct-solution algorithm 


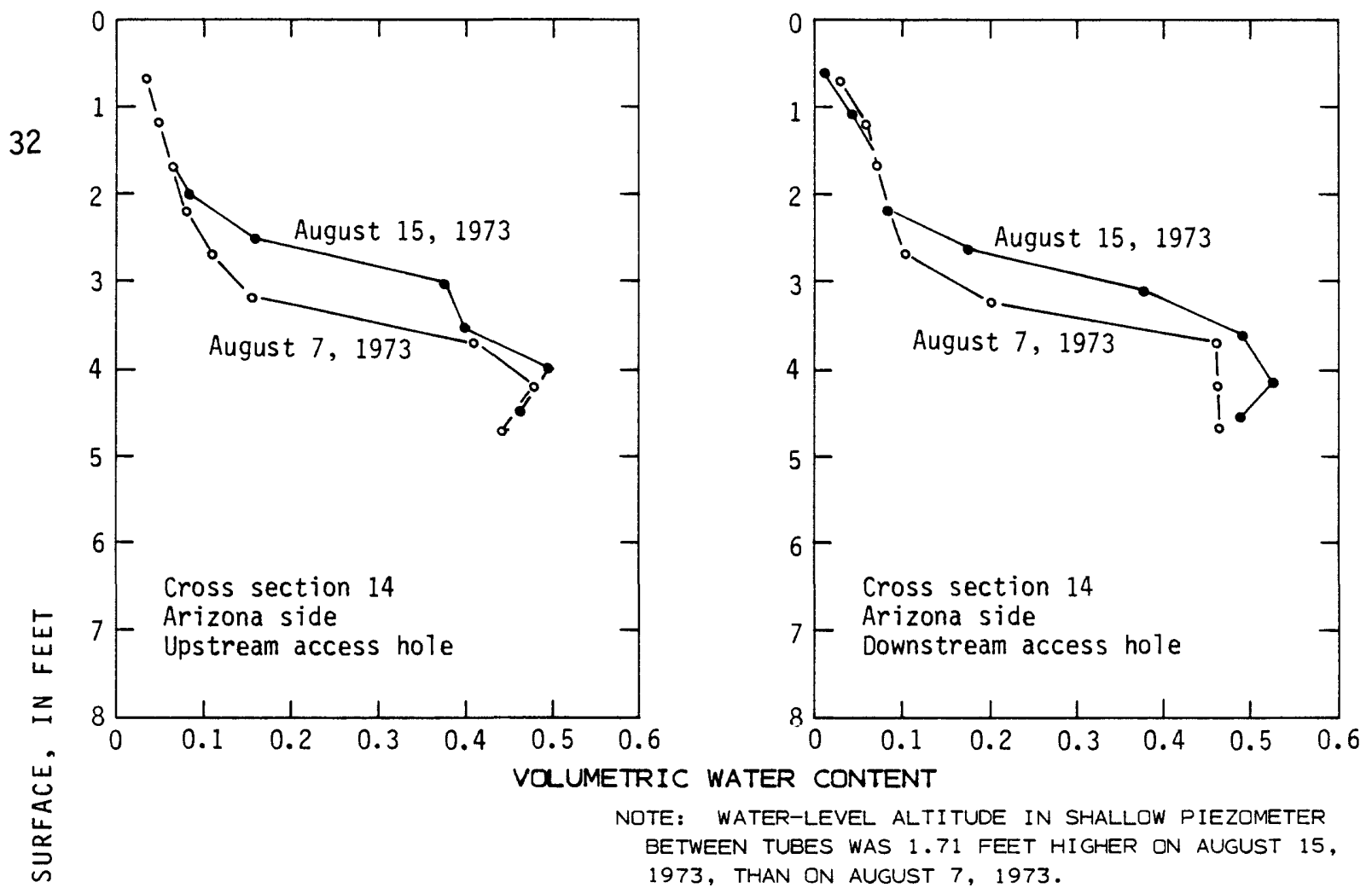
1973, THAN ON AUGUST 7, 1973.

2
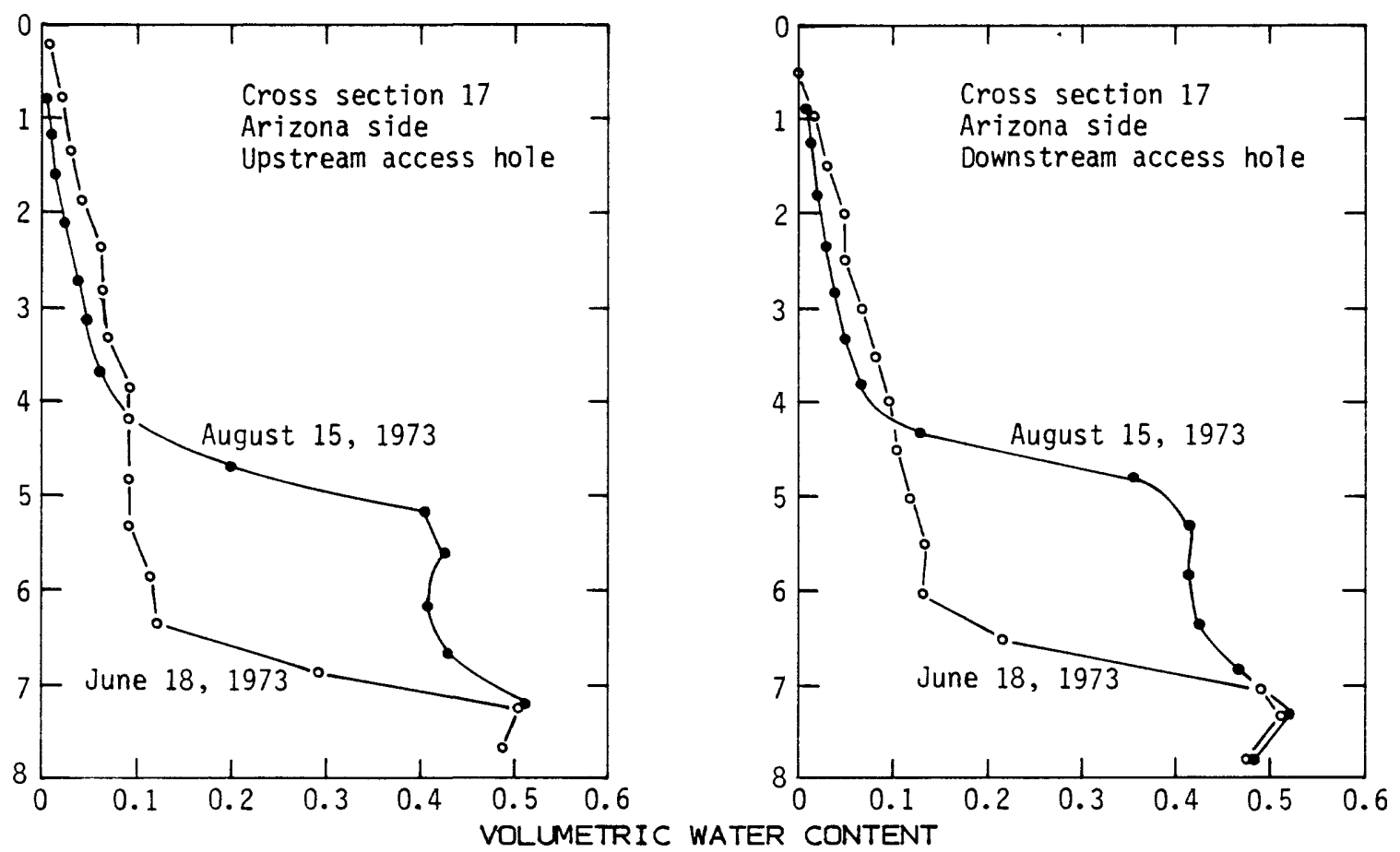

NOTE: WATER-LEVEL ALTITUDE IN SHALLOW PIEZOMETER BETWEEN TUBES WAS 2.15 FEET HIGHER ON AUGUST 15 , 1973, THAN ON JUNE 18, 1973.

Figure 11.--Selected soil-moisture profiles. Volumetric water content is volume of water per unit volume of soil (dimensionless). 
Table 1.--Estimated specific yields at cross sections in the Yuma area

[Sites are about 100 feet from the river. Each site includes two neutron-probe access holes from which soil-moisture data were collected before and during the river-stage event of August 14-17, 1973]

\begin{tabular}{ccc}
\hline Cross section & $\begin{array}{c}\text { Site on Arizona } \\
\text { side of river }\end{array}$ & $\begin{array}{c}\text { Site on California } \\
\text { side of river }\end{array}$ \\
\hline 18 & 0.18 & 0.18 \\
17 & .28 & .28 \\
16 & .23 & .23 \\
15 & .19 & .19 \\
14 & .15 & .20 \\
13 & 1.13 & .13 \\
12 & .15 & .15 \\
11 & .17 & .17 \\
10 & .21 & .21 \\
9 & .23 & .23 \\
8 & 1.22 & .22 \\
7 & .18 & .18 \\
6 & .20 & .15 \\
5 & .20 & .15 \\
4 & .23 & .23 \\
3 & .20 & 1.20 \\
2 & 1.15 & 1.15 \\
1 & .22 & .22 \\
\hline
\end{tabular}

${ }^{1}$ Soil-moisture data not available.

using alternating-direction diagonal ordering (Larson, 1978) was found to be efficient in solving the linear equations simultaneously.

\section{Transient-Flow Models}

Transient-flow models were developed to estimate distributions of hydraulic conductivity at the cross sections; steady-state models cannot be used to estimate hydraulic-conductivity values because the flcw quantities entering the far-cluster boundaries are not known. The transient-flow models simulated head changes in the aquifer caused by changes in river stage. The simulated head changes with time were compared to observed head changes at each of the 12 piezometer locations. These comparisons gave a basis for trial-and-error adjustments of $K_{h}$ and $K_{v}$ values in zones within the cross sections. 
The equation for simulating head changes in the cross sections

$$
\frac{\partial}{\partial x}\left(K_{h} \frac{\partial h^{*}}{\partial x}\right)+\frac{\partial}{\partial z}\left(K_{v} \frac{\partial h^{*}}{\partial z}\right)=S_{s} \frac{\partial h^{*}}{\partial t}
$$

where

$$
\begin{aligned}
& h^{*}=\text { head change since start of river-stage event, } \\
& S_{S}=\text { specific storage, and } \\
& t=\text { time. }
\end{aligned}
$$

An assumption made in applying this equation is that the aquifer is isotropic in the horizontal plane.

For the transient analysis, the simplifying assumption was made that the water table could be represented as being horizontal and at a fixed elevation. This representation of the water table is reasonable for head changes that are small compared to the saturated thickness represented by the cross section.

The vertical boundaries were treated as no-flow boundaries. The cross sections were extended beyond the far clusters to insure that head changes at the vertical boundaries would be insignificant. The lower boundary also was treated as a no-flow boundary.

The part of the upper boundary representing the river was treated as a specified-head boundary at which $h^{*}$ varied as a function of time to approximate observed changes in river stage with time. For the rest of the upper boundary, a function was needed to describe the flux going into or out of storage due to saturation or desaturation at the water table $\left(q_{w t}\right)$. The correct function initially was thought to be

$$
q_{w t}=S_{y} \frac{\partial h^{*}}{\partial t}
$$

where

$$
\begin{aligned}
S_{y}= & \text { the specific yield of the aquifer material } \\
& \text { at the water table. }
\end{aligned}
$$

With this boundary function, studies using electrical-analog models indicated that the theoretical head changes in the aquifer resulting from river-stage changes were slower that the corresponding observed head changes in the aquifer. From these studies, the inference was made that the disparities were due to the delayed yield to or from storage at the water table. 
The finite-difference model program (Trescott and others, 1976) does not have the capability of simulating effects of delayed yield. $E$. $P$. Weeks (written commun., 1976) suggested an adaptation of a procedure for approximating effects of delayed yield in mathematical models proposed by Cooley (1972). A description of this adaptation as applied for this study follows.

The procedure proposed by Cooley (1972) involves an aquifer overlain by a poorly permeable confining layer with a thickness $(m)$, a vertical hydraulic conductivity $(K)$, and a specific yield $\left(S_{y}\right)$. The solution for the effects of delayed storage at a point on the aquifer surface for time step $n$ in a transient simulation was given as

$$
v_{d}^{(n)}=x^{(n)}-x^{(n)},
$$

where

$$
\begin{aligned}
v_{d}(n)= & \text { the volumetric rate of flow stored or released } \\
& \text { from water-table storage per unit aquifer- } \\
& \text { surface area, } \\
x^{\prime(n)}= & \text { the explicit component of the rate, and } \\
x^{(n)=} & \text { the implicit component of the rate. }
\end{aligned}
$$

These components are given as

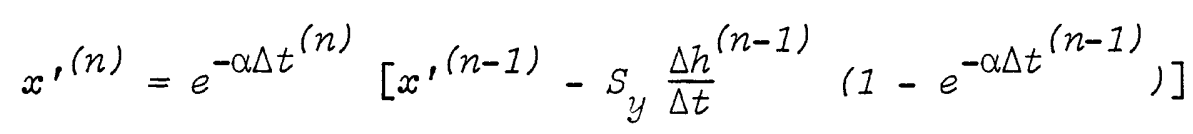

and

$$
\left.x^{(n)}=S_{y}{\frac{\Delta h^{(n)}}{\Delta t}}^{\left(1-e^{-\alpha \Delta t}(n)\right.}\right]
$$

where

$$
\begin{aligned}
\alpha & =K /\left(S_{y} m\right), \\
\Delta t(n) & =\text { length of time step } n, \\
\Delta h(n) & =\text { change in head at the base of the confining } \\
& \text { layer during time step } n,
\end{aligned}
$$

and subject to the initial conditions

$$
x^{\prime(0)}, \frac{\Delta h}{\Delta t}^{(0)}=0
$$


Equations 5, 6, and 7 are derived from equations 9 and 10 in the analysis by Cooley (1972, p. 1048, 1049).

The parameter $\alpha$, as presented by Cooley (1972), describes properties of a single overlying confining layer. In the Yuma area the effects of delayed yield were attributed to clayey and silty layers at or near the water table. The areal extent and hydraulic properties of the layers were unknown. The parameter $\alpha$, therefore, was used as a delay index that was adjusted so that computed aquifer responses would more nearly match the observed responses. The equations later were simplified by defining the new parameter:

$$
S_{0}=S_{y}\left[1-e^{-\alpha \Delta t}\right]
$$

If $\Delta t$ is constant for all time steps, equations 6 and 7 can be rewritten as:

$$
x^{\prime(n)}=\left(1-S_{0} / S_{y}\right)\left[x^{(n-1)}-S_{0} \frac{\Delta h}{\Delta t}^{(n-1)}\right]
$$

and

$$
x^{(n)}=S_{0}{\frac{\Delta h^{(n)}}{\Delta t}}
$$

The $S_{0}$ values, which were considered to be initial storage coefficients, were input for water-table nodes and were adjusted as needed to obtain the proper delay effects.

The $v_{d}$ function, which was used as an approximation of $q_{w t}$ was added to the right-hand side of the finite-difference approximation of equation 3 for nodes at the water table. This substitution provided the additional capability needed to obtain good correlation between computed and observed head values.

To illustrate the effects of the delayed storage function on the computed hydrographs, several model runs were made using the riverstage hydrograph for August 14-17, 1973, at cross section 8 . A transmissivity of $40,000 \mathrm{ft}^{2} / \mathrm{d}$ and a ratio of horizontal to vertical hydraulic conductivity of 10 to 1 were used. For a specific yield of 0.22 , the effects of various ratios of $S_{0} / S_{y}$ on the response of the aquifer near the water table are shown in figure 12 . 


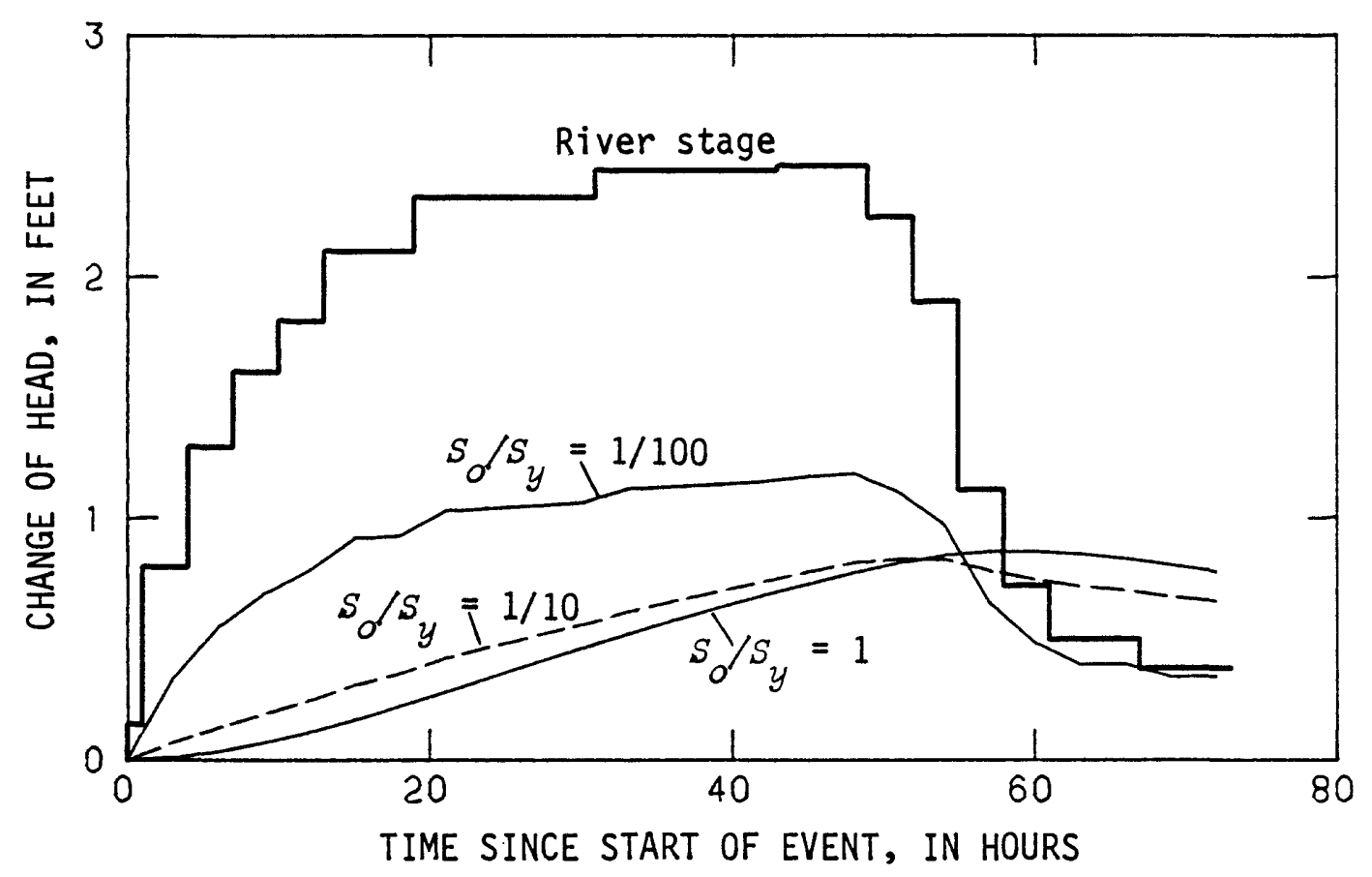

Figure 12.--Effects of various ratios of $S_{O} / S_{y}$ on response of the aquifer at location of piezometer AZ4. The piezometer is 530 feet from river at cross section 8 . 


\section{Grid Dimensions}

The cross sections were modeled as matrices of 40 columns and from 10 to 14 rows of blocks. Blocks simulating river segments ranged from 10 to $70 \mathrm{ft}$ horizontally, depending on the width of the river and the position of the simulated river-width segment relative to the edge of the river. Blocks beyond the river simulated distance segments that ranged from $10 \mathrm{ft}$ to more than $1,000 \mathrm{ft}$. The simulated distance of each block beyond the far cluster usually increased by a factor of about 1.5 over that of the adjacent block nearer the river. Vertically, simulated dimensions of blocks ranged from 5 to $30 \mathrm{ft}$. Parts of the model grids near the piezometers are shown in figures 13-29.

\section{Input and Output}

For transient simulations, input data included (1) dimensions of the blocks, (2) hydraulic conductivity of each block, (3) ratio of vertical to horizontal hydraulic conductivity, (4) initial storage coefficient at the water table, (5) specific yield at the water table, (6) specific storage below the water table, (7) location of the river, (8) locations of the piezometers, (9) step approximation of the change in river stage with time, and (10) observed head changes in the piezometers. Program output generally included (1) maximum simulated head at each node, (2) graphs showing observed and computed head changes at each piezometer location, and (3) a cumulative mass balance.

For steady-state simulations, additional input consisted of the average annual altitude of the river surface and the average annual water-level altitudes at each of the piezometers for a given year and average annual flux normal to the water table. The hydraulicconductivity values beyond the far clusters, river-stage changes, and observed head changes in piezometers were not used in steady-state simulations. The average annual heads in the far-cluster piezometers were used to define the specified-head vertical boundaries. An algorithm added to the model program assigned specified head values at the vertical boundaries as follows: (1) Nodes corresponding to a piezometer level-shallow, medium, or deep-were assigned the values of average annual head determined for the piezometer, (2) nodes between piezometer levels were assigned values by interpolation on the basis of vertical hydraulic conductivity and distance, and (3) nodes below the levels of deep piezometers were assigned values by extrapolation on the basis of the relations of head change, vertical hydraulic conductivity, and distance determined for nodes between medium and deep piezometer levels. The average annual altitude of the river surface was used to define the specified-head boundary corresponding to the river. Output consisted of the flow into or out of each specified-head block, a mass balance of sources and discharges of water, and a matrix showing the head at each block. 


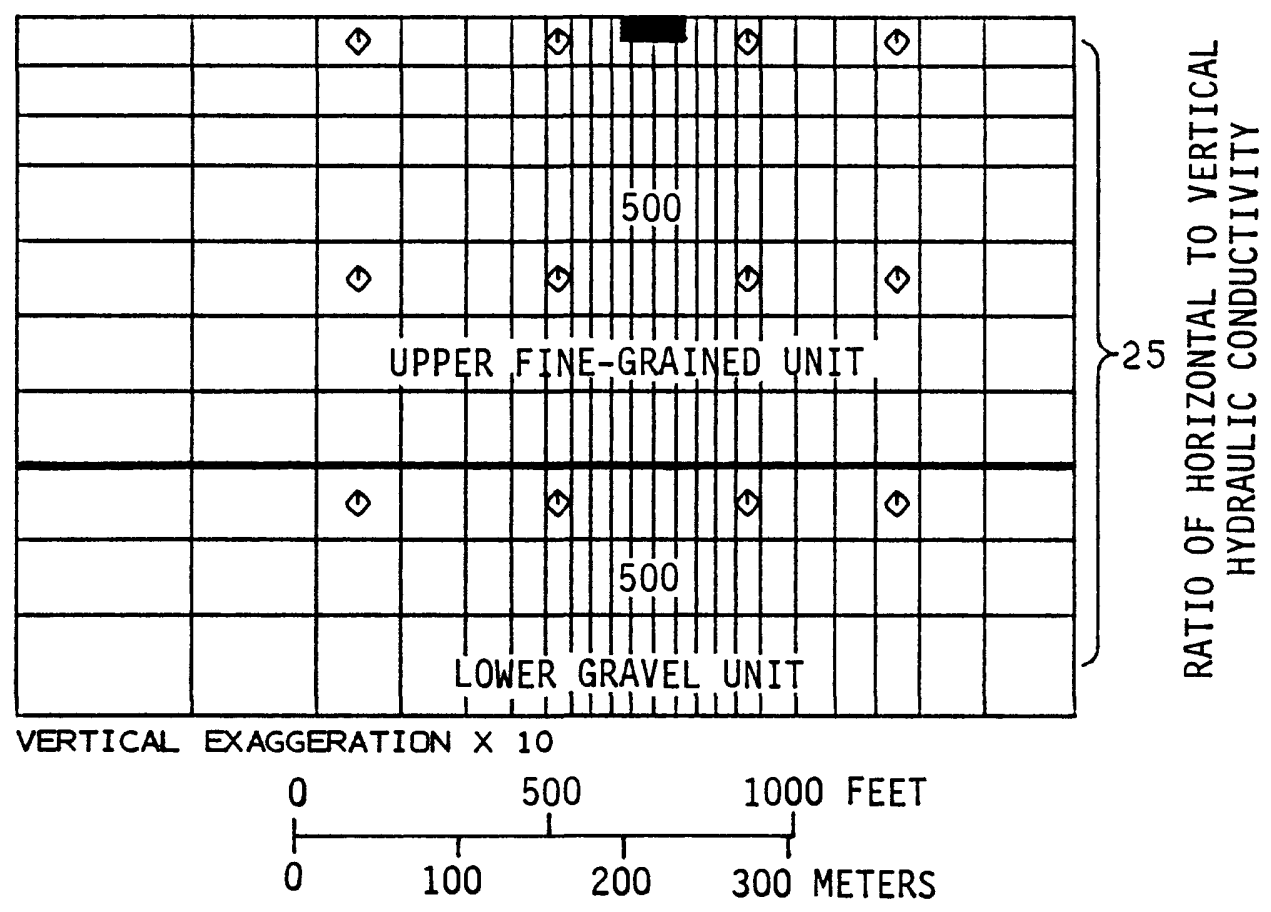

EXPLANATION

BLOCK IN ACTIVE PART OF FINITE-
DIFFERENCE GRID

RIVER LOCATION AS REPRESENTED IN STEADY-STATE SIMULATIONS

$\checkmark \quad$ PIEZOMETER LOCATION

500

HORIZONTAL HYDRAULIC CONDUCTIVITY

OF UNIT, IN FEET PER DAY

Figure 13.--Model dimensions and various hydraulic properties near piezometers for model of cross section 18. 


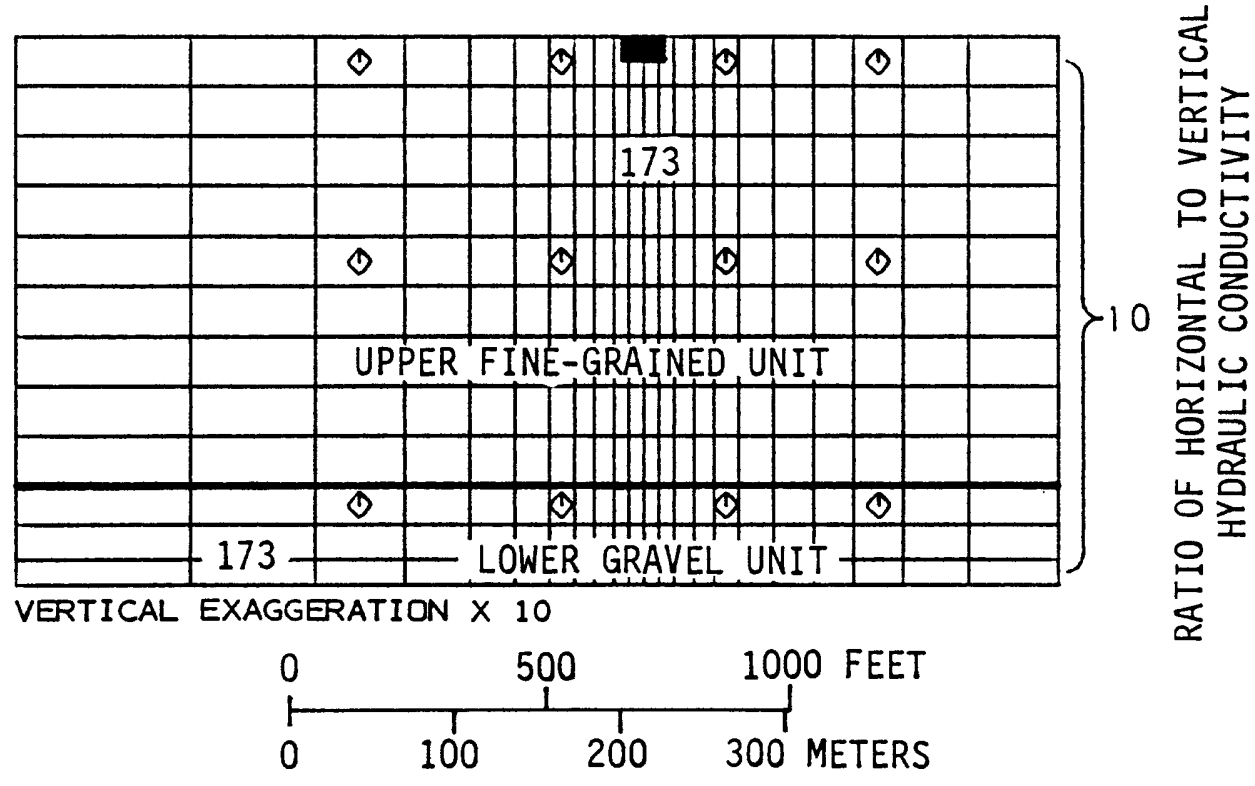

EXPLANATION BLOCK IN ACTIVE PART OF FINITE-
DIFFERENCE GRID

RIVER LOCATION AS REPRESENTED IN STEADY-STATE SIMULATIONS

$\diamond \quad$ PIEZOMETER LOCATION

173 HORIZONTAL HYDRAULIC CONDUCTIVITY OF UNIT, IN FEET PER DAY

Figure 14.--Model dimensions and various hydraulic properties near piezometers for model of cross section 17 . 


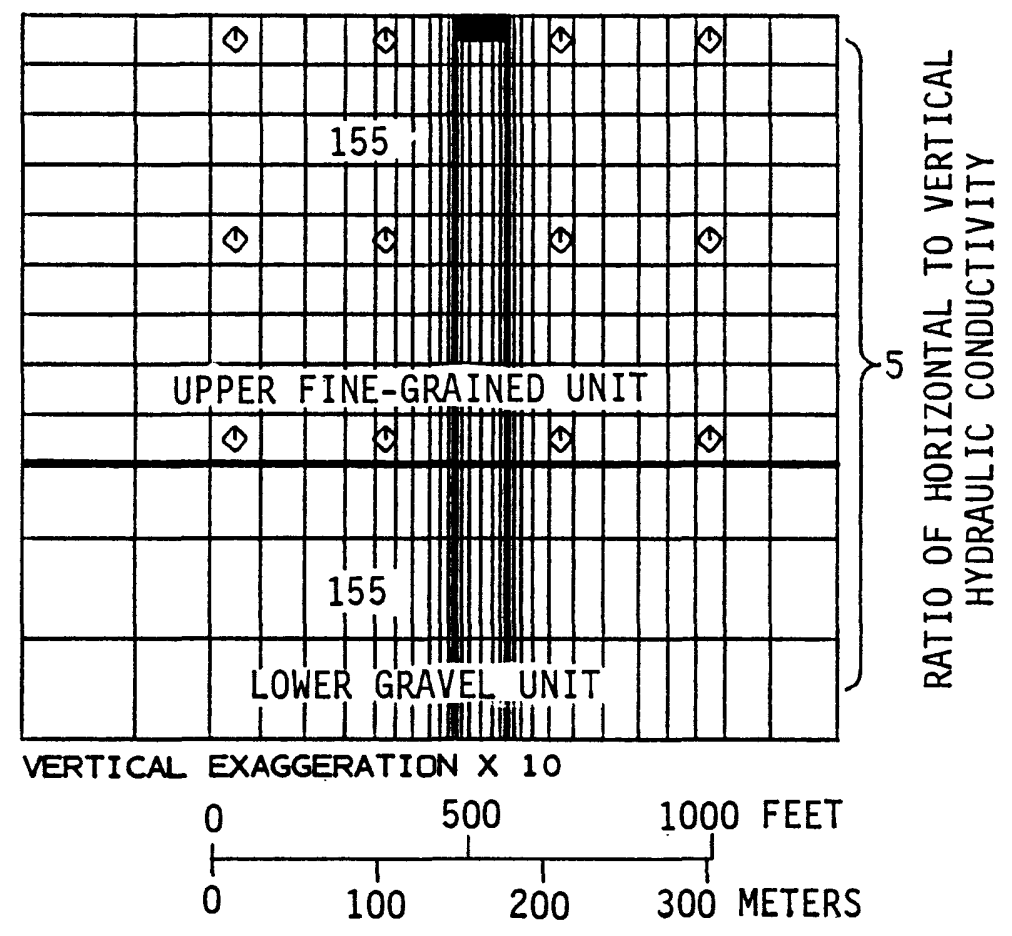

EXPLANATION

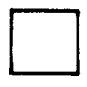

BLOCK IN ACTIVE PART OF FINITE-

DIFFERENCE GRID

RIVER LOCATION AS REPRESENTED IN

STEADY-STATE SIMULATIONS

$\diamond \quad$ PIEZOMETER LOCATION

155 HORIZONTAL HYDRAULIC CONDUCTIVITY

OF UNIT, IN FEET PER DAY

Figure 15.--Model dimensions and various hydraulic properties near piezometers for model of cross section 16. 


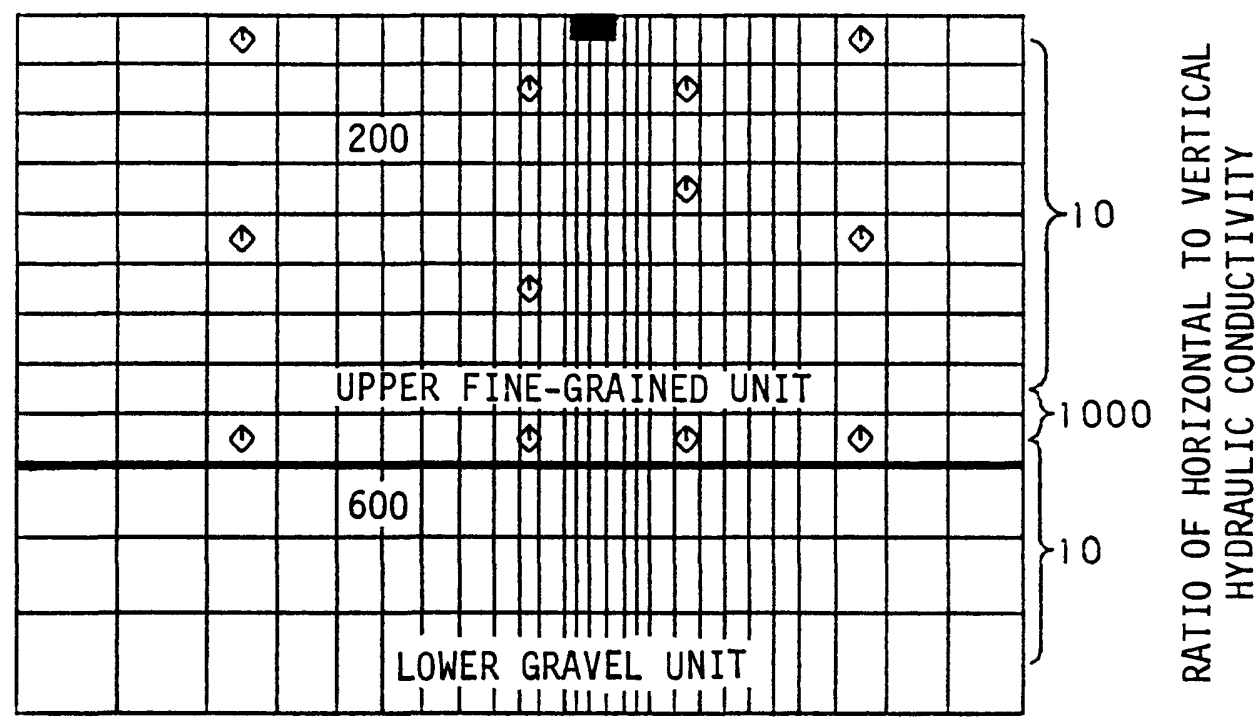

VERTICAL EXAGGERATION $\times 10$

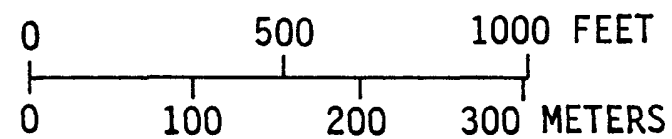

EXPLANATION

$\square$ BLOCK IN ACTIVE PART OF FINITEDIFFERENCE GRID

RIVER LOCATION AS REPRESENTED IN STEADY-STATE SIMULATIONS

$\checkmark \quad$ PIEZOMETER LOCATION

200 HORIZONTAL HYDRAULIC CONDUCTIVITY OF UNIT, IN FEET PER DAY

Figure 16.--Model dimensions and various hydraulic properties near piezometers for model of cross section 15. 


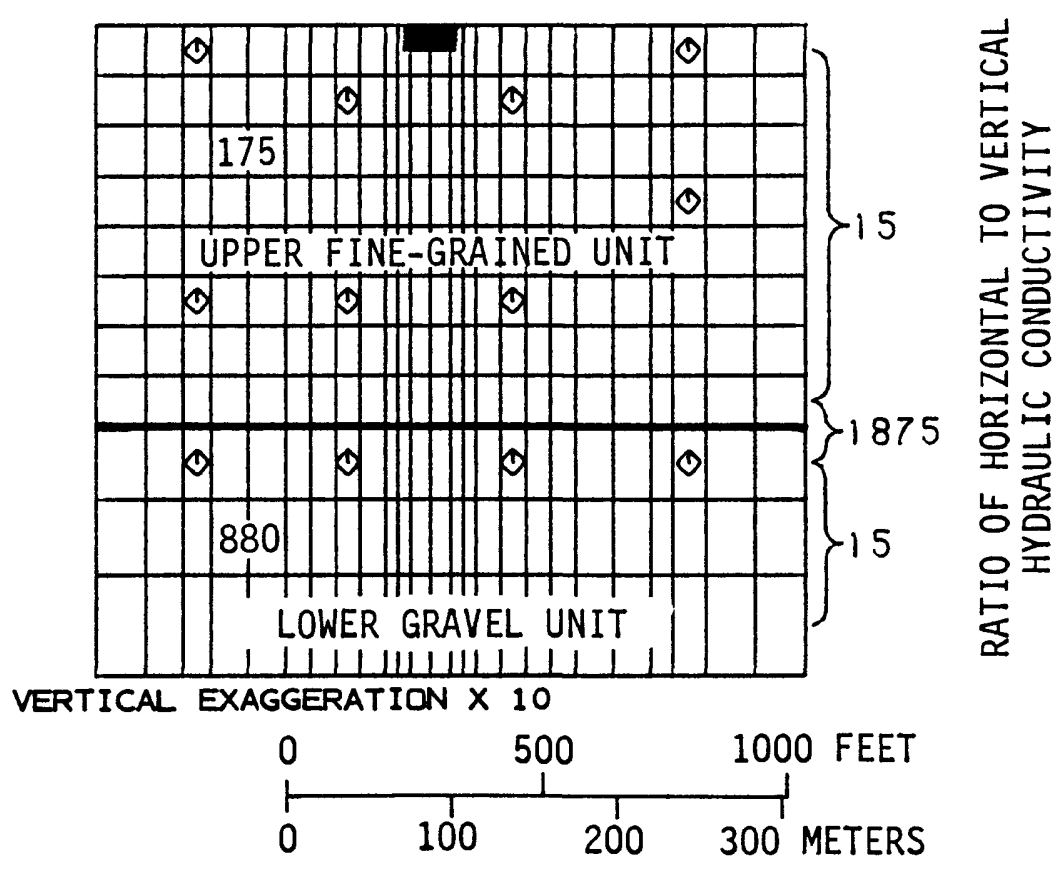

EXPLANATION

$\square$ BLOCK IN ACTIVE PART OF FINITEDIFFERENCE GRID

$\square$ RIVER LOCATION AS REPRESENTED IN STEADY-STATE SIMULATIONS

$\checkmark \quad$ PIEZOMETER LOCATION

175 HORIZONTAL HYDRAULIC CONDUCTIVITY

OF UNIT, IN FEET PER DAY

Figure 17.--Model dimensions and various hydraulic properties near piezometers for model of cross section 14. 


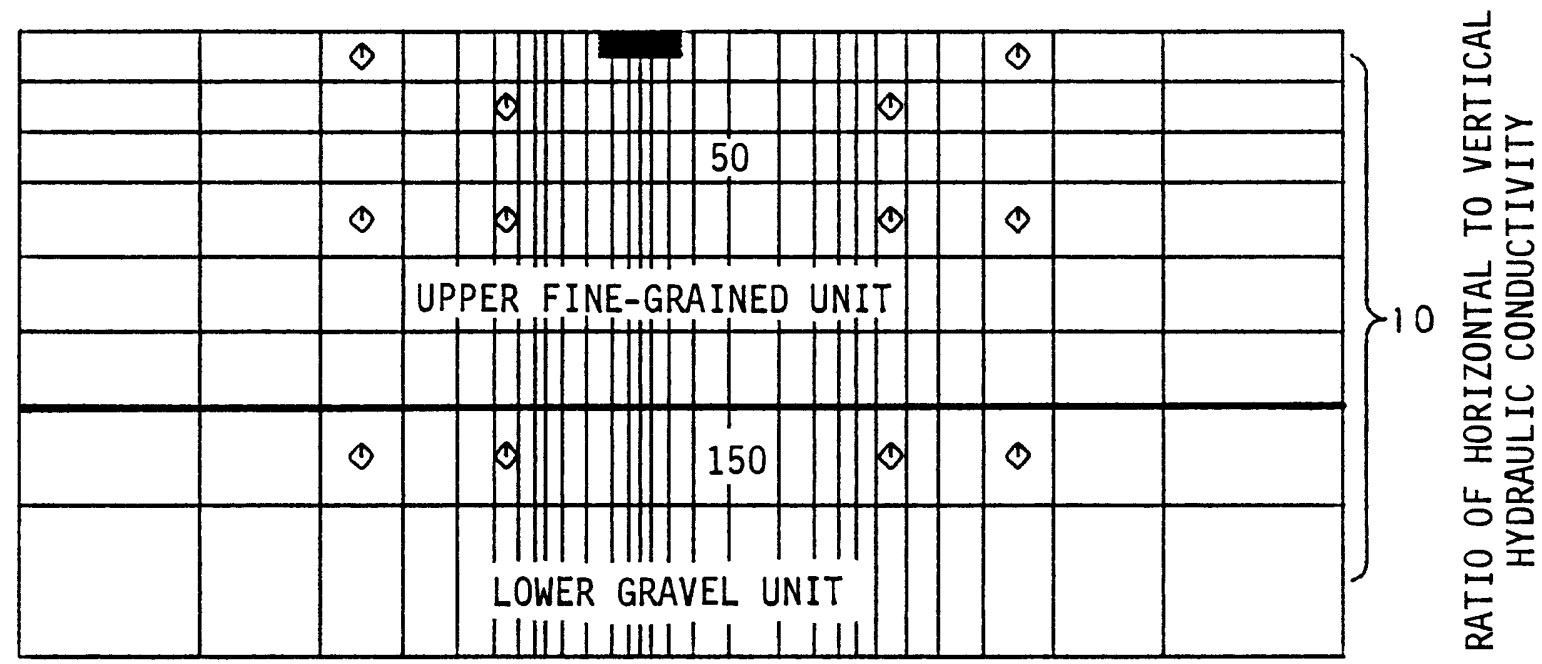

VERTICAL EXAGGERATION $\times 10$

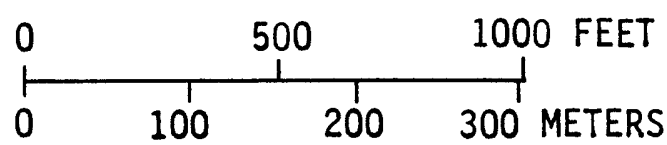

EXPLANATION

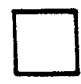

BLOCK IN ACTIVE PART OF FINITE-

DIFFERENCE GRID

RIVER LOCATION AS REPRESENTED IN

STEADY-STATE SIMULATIONS

$\diamond \quad$ PIEZOMETER LOCATION

50 HORIZONTAL HYDRAULIC CONDUCTIVITY

OF UNIT, IN FEET PER DAY

Figure 18.--Model dimensions and various hydraulic properties near piezometers for model of cross section 13. 


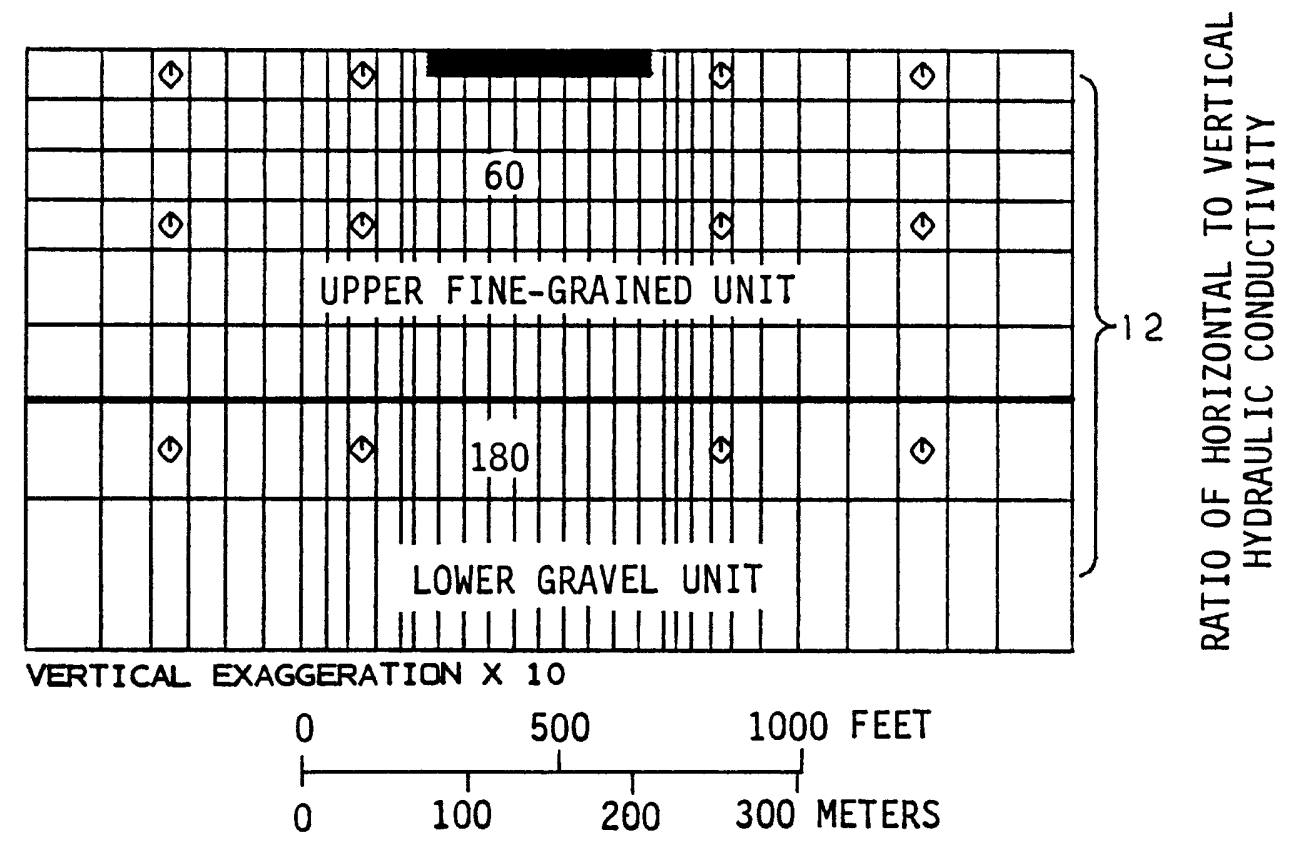

EXPLANATION

BLOCK IN ACTIVE PART OF FINITE-
DIFFERENCE GRID

RIVER LOCATION AS REPRESENTED IN

STEADY-STATE SIMULATIONS

$\checkmark \quad$ PIEZOMETER LOCATION

60 HORIZONTAL HYDRAULIC CONDUCTIVITY

OF UNIT, IN FEET PER DAY

Figure 19.--Model dimensions and various hydraulic properties near piezometers for model of cross section 11 . 


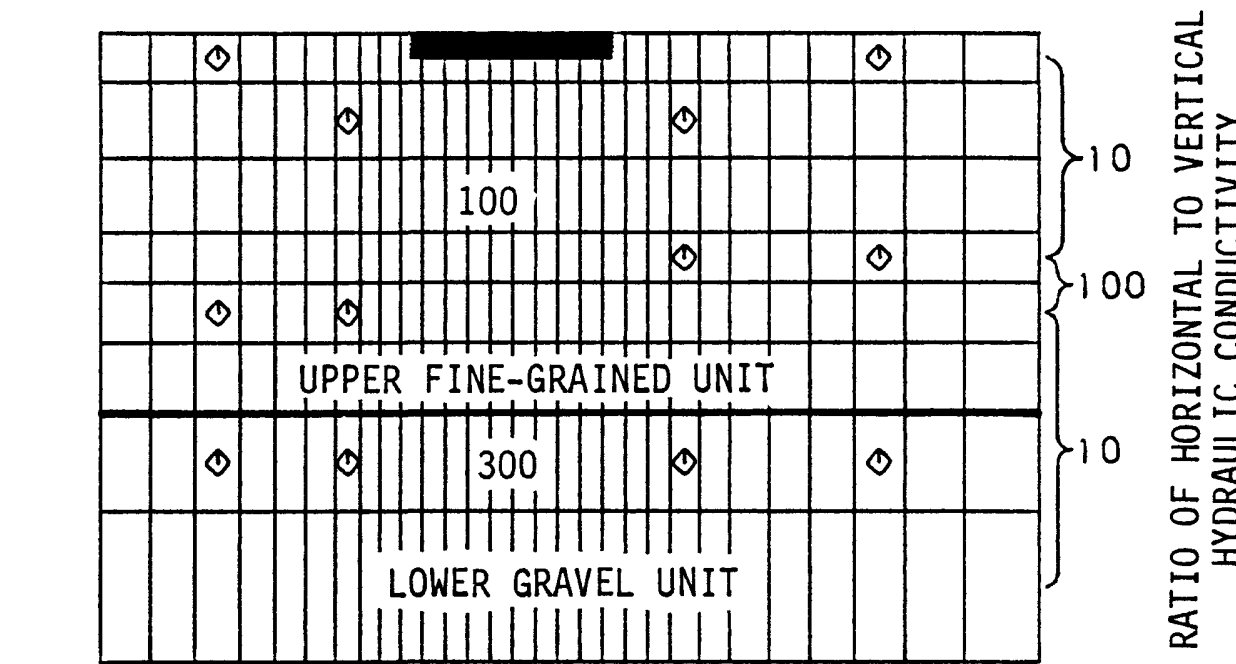

VERTICAL EXAGGERATION $\times 10$

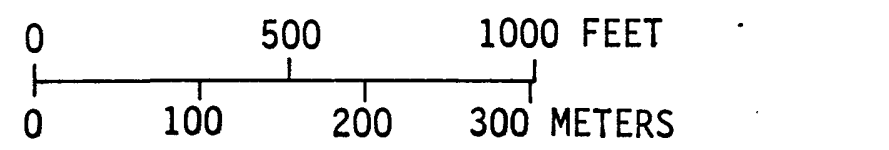

EXPLANATION
BLOCK IN ACTIVE PART OF FINITE-
DIFFERENCE GRID

RIVER LOCATION AS REPRESENTED IN STEADY-STATE SIMULATIONS

$\checkmark \quad$ PIEZOMETER LOCATION

100

HORIZONTAL HYDRAULIC CONDUCTIVITY

OF UNIT, IN FEET PER DAY

Figure 20.--Model dimensions and various hydraulic properties near piezometers for model of cross section 10. 


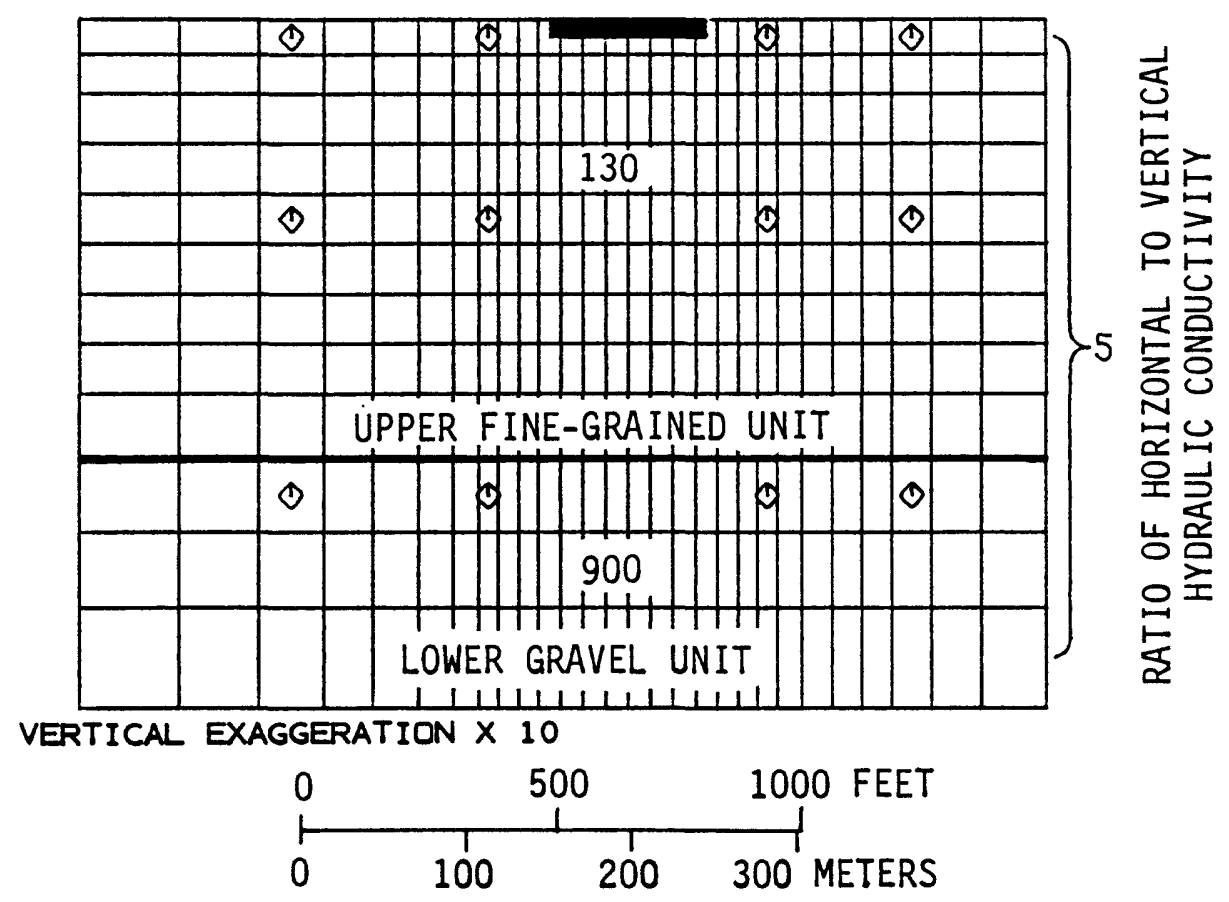

EXPLANATION

$\square$ BLOCK IN ACTIVE PART OF FINITE-

DIFFERENCE GRID

RIVER LOCATION AS REPRESENTED IN

STEADY-STATE SIMULATIONS

$\checkmark \quad$ PIEZOMETER LOCATION

130 HORIZONTAL HYDRAULIC CONDUCTIVITY

OF UNIT, IN FEET PER DAY

Figure 21.--Model dimensions and various hydraulic properties near piezometers for model of cross section 9. 


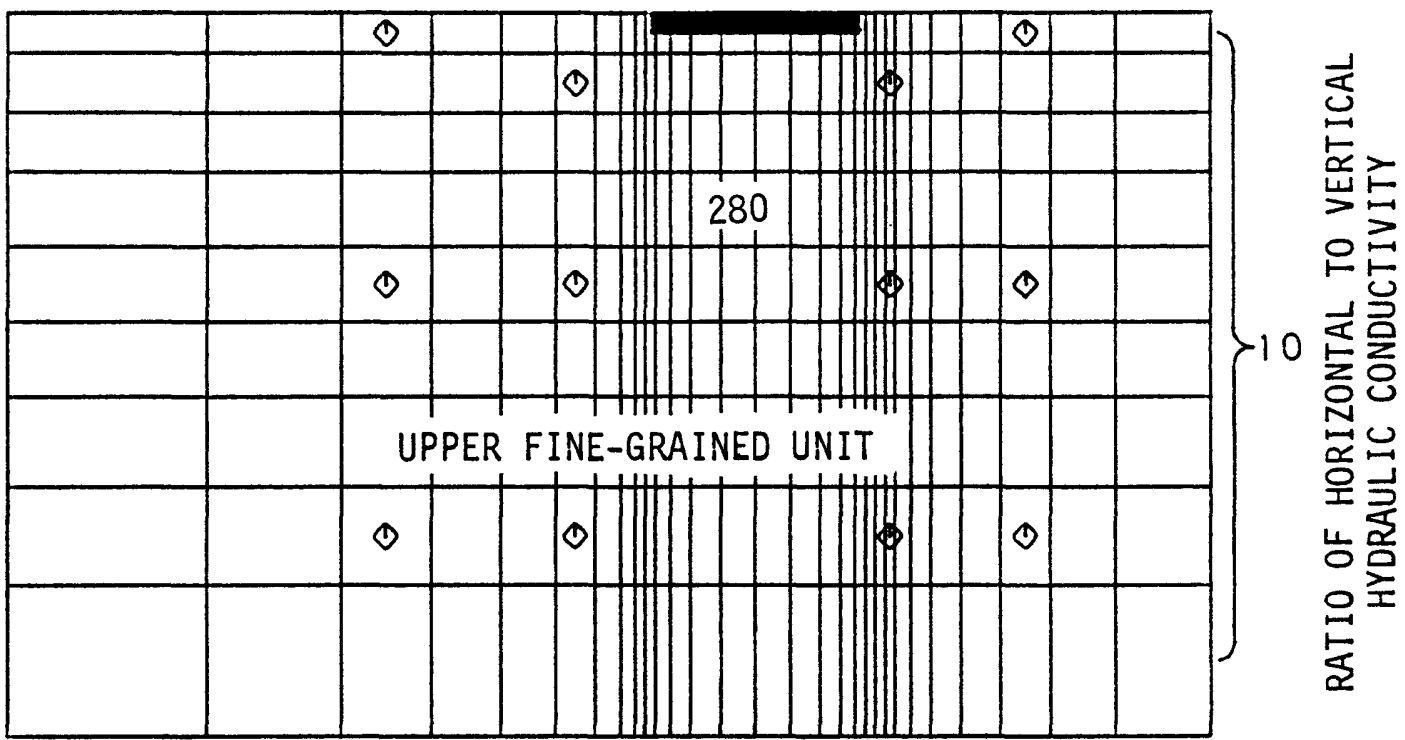

VERTICAL EXAGGERATION $\times 10$

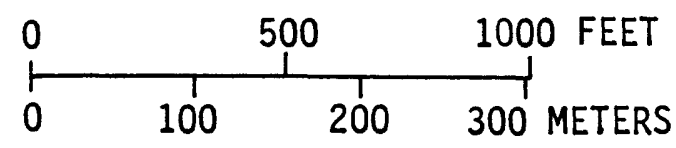

EXPLANATION

BLOCK IN ACTIVE PART OF FINITEDIFFERENCE GRID

RIVER LOCATION AS REPRESENTED IN STEADY-STATE SIMULATIONS

$\diamond \quad$ PIEZOMETER LOCATION

230 HORIZONTAL HYDRAULIC CONDUCTIVITY OF UNIT, IN FEET PER DAY

Figure 22.--Model dimensions and various hydraulic properties near piezometers for model of cross section 8. 


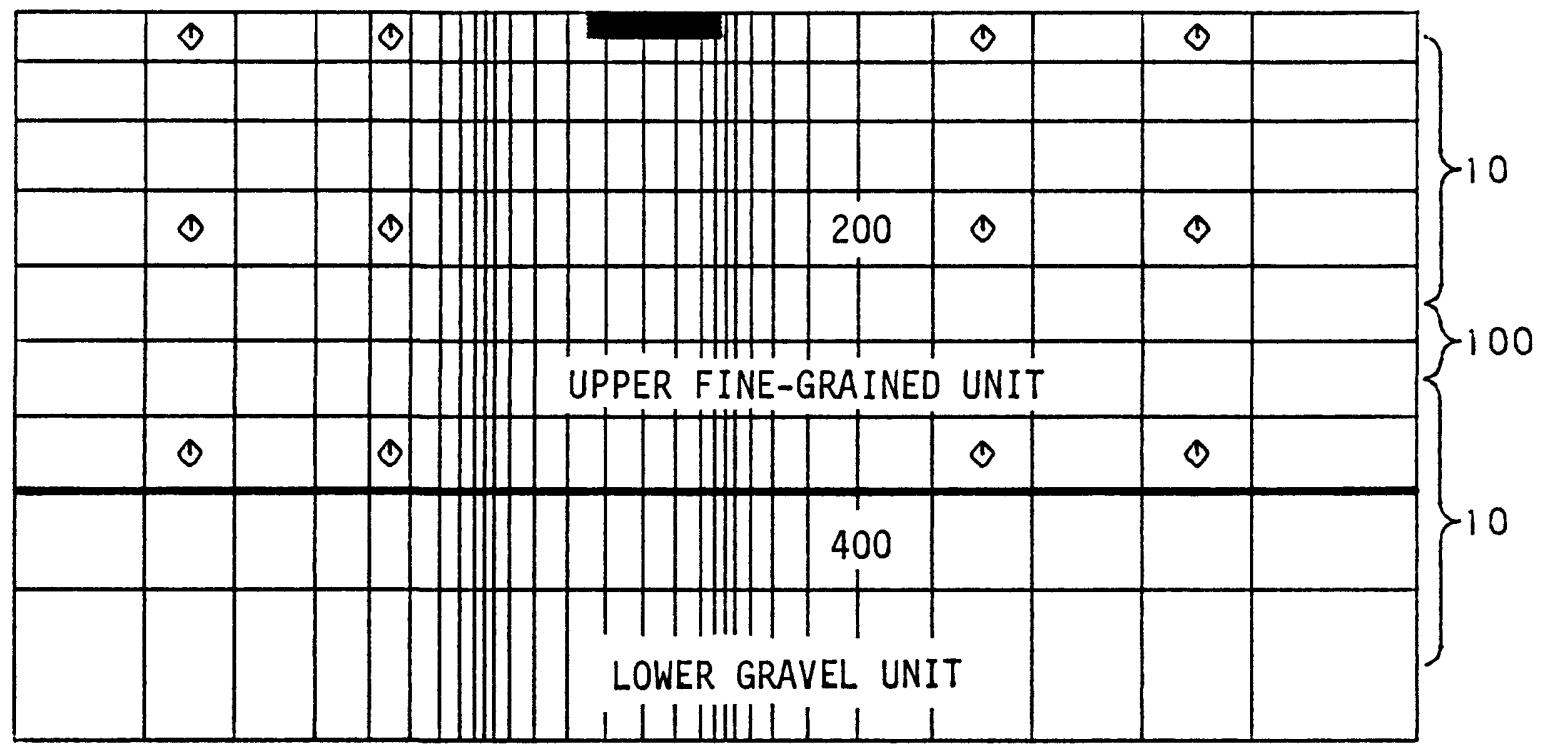

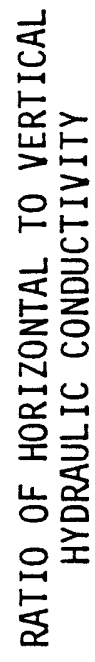

VERTICAL EXAGGERATION $\times 10$

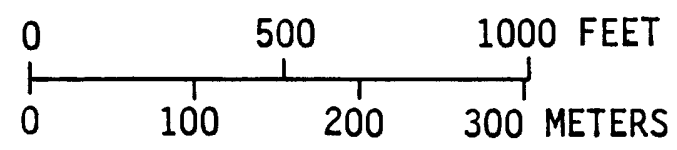

EXPLANATION

BLOCK IN ACTIVE PART OF FINITE-

DIFFERENCE GRID

RIVER LOCATION AS REPRESENTED IN

STEADY-STATE SIMULATIONS

$\checkmark \quad$ PIEZOMETER LOCATION

200 HORIZONTAL HYDRAULIC CONDUCTIVITY

OF UNIT, IN FEET PER DAY

Figure 23.--Model dimensions and various hydraulic properties near piezometers for model of cross section 7. 
50

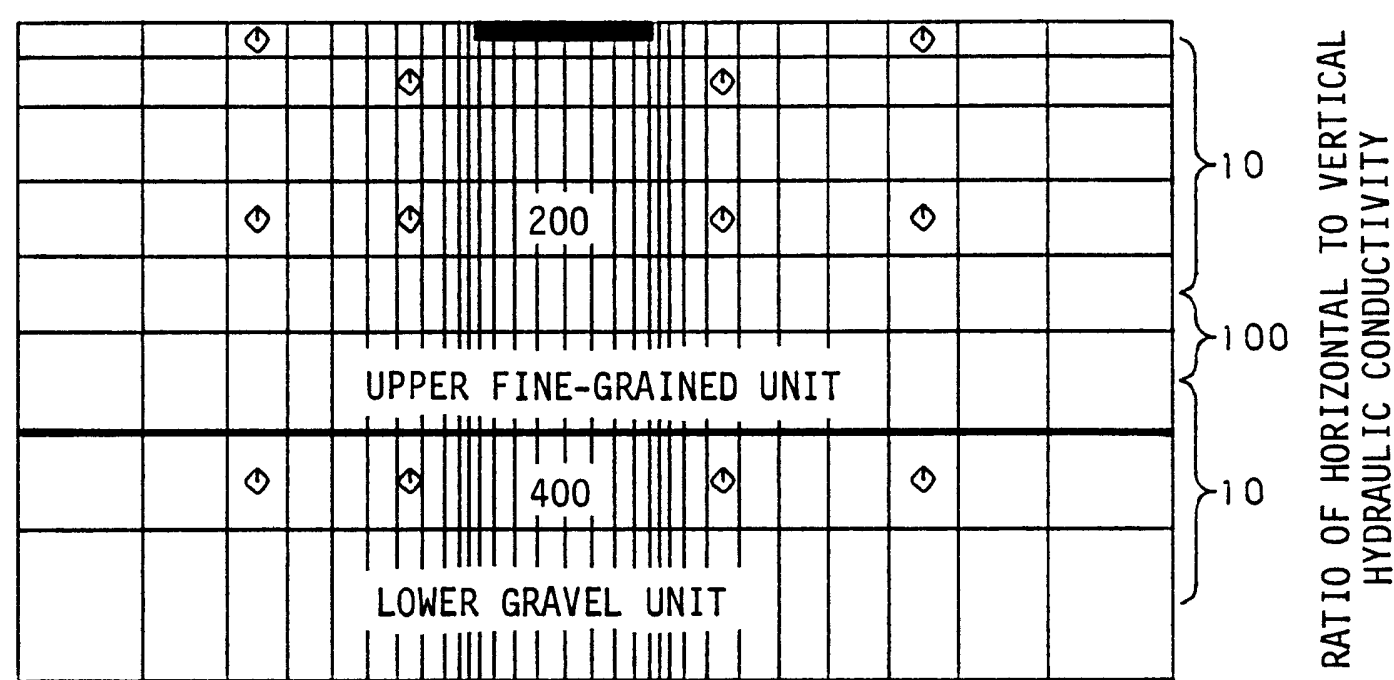

VERTICAL EXAGGERATION $\times 10$

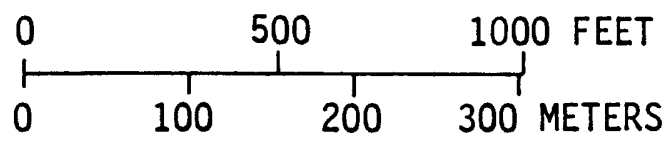

EXPLANATION

BLOCK IN ACTIVE PART OF FINITE-
DIFFERENCE GRID

RIVER LOCATION AS REPRESENTED IN

STEADY-STATE SIMULATIONS

$\diamond \quad$ PIEZOMETER LOCATION

200 HORIZONTAL HYDRAULIC CONDUCTIVITY

OF UNIT, IN FEET PER DAY

Figure 24.--Model dimensions and various hydraulic properties near piezometers for model of cross section 6 . 


\section{1}
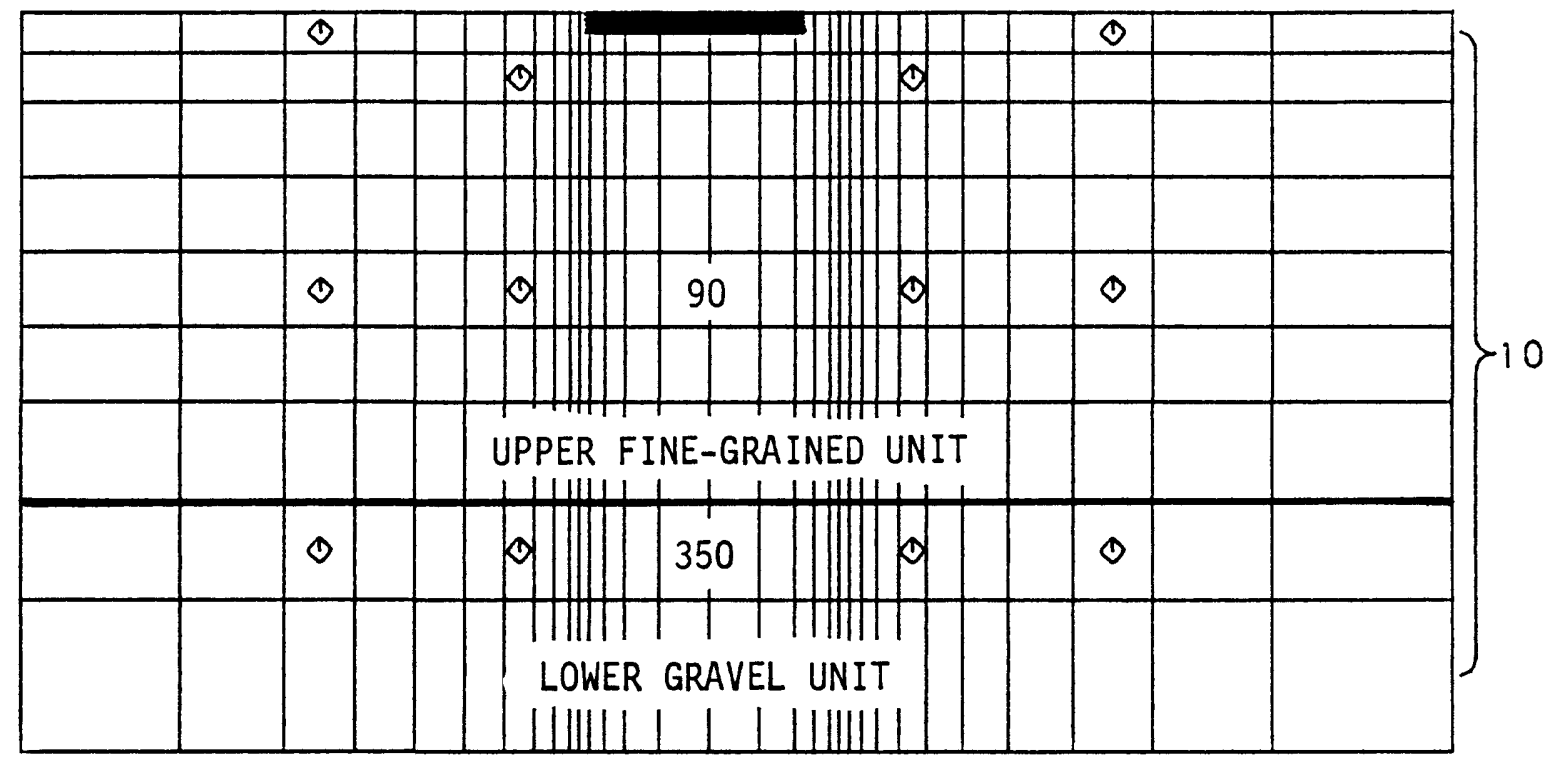

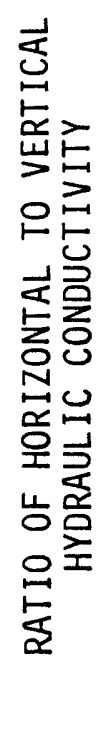

VERTICAL EXAGGERATION $\times 10$

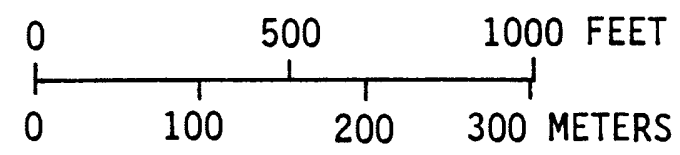

EXPLANATION

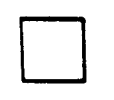
BLOCK IN ACTIVE PART OF FINITE-
DIFFERENCE GRID

RIVER LOCATION AS REPRESENTED IN

STEADY-STATE SIMULATIONS

$\diamond \quad$ PIEZOMETER LOCATION

90

HORIZONTAL HYDRAULIC CONDUCTIVITY

OF UNIT, IN FEET PER DAY

Figure 25.--Model dimensions and various hydraulic properties near piezometers for model of cross section 5. 


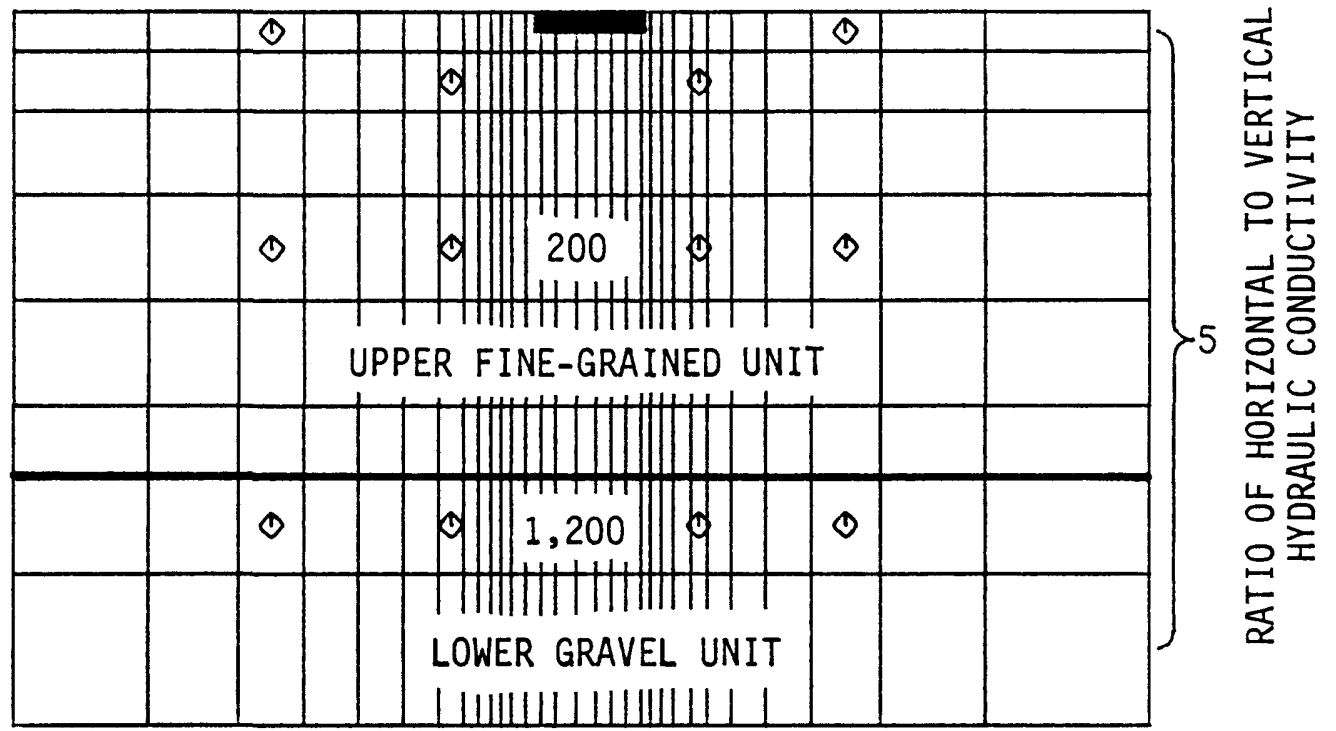

VERTICAL EXAGGERATION $\times 10$

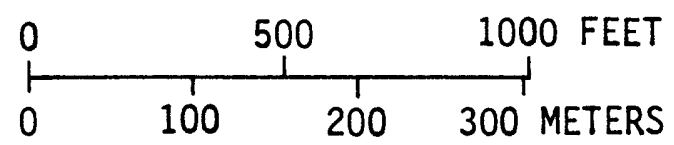

EXPLANATION

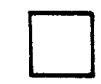

BLOCK IN ACTIVE PART OF FINITE-
DIFFERENCE GRID

RIVER LOCATION AS REPRESENTED IN

STEADY-STATE SIMULATIONS

$\diamond \quad$ PIEZOMETER LOCATION

200 HORIZONTAL HYDRAULIC CONDUCTIVITY

OF UNIT, IN FEET PER DAY

Figure 26.--Model dimensions and various hydraulic properties near piezometers for model of cross section 4 . 


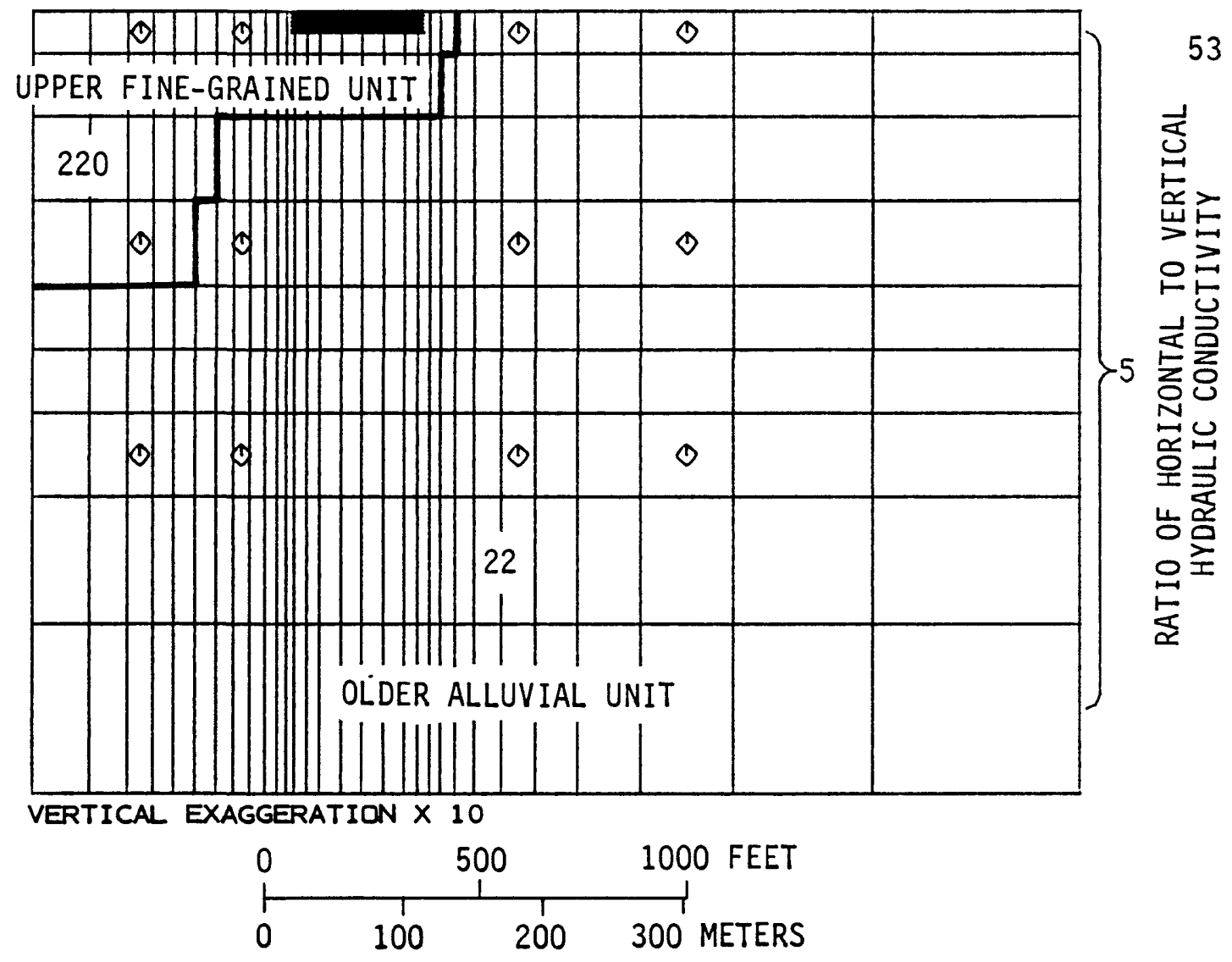

EXPLANATION

BLOCK IN ACTIVE PART OF FINITE-

DIFFERENCE GRID

RIVER LOCATION AS REPRESENTED IN

STEADY-STATE SIMULATIONS

$\checkmark \quad$ PIEZOMETER LOCATION

220 HORIZONTAL HYDRAULIC CONDUCTIVITY

OF UNIT, IN FEET PER DAY

Figure 27.--Model dimensions and various hydraulic properties near piezometers for model of cross section 3 . 


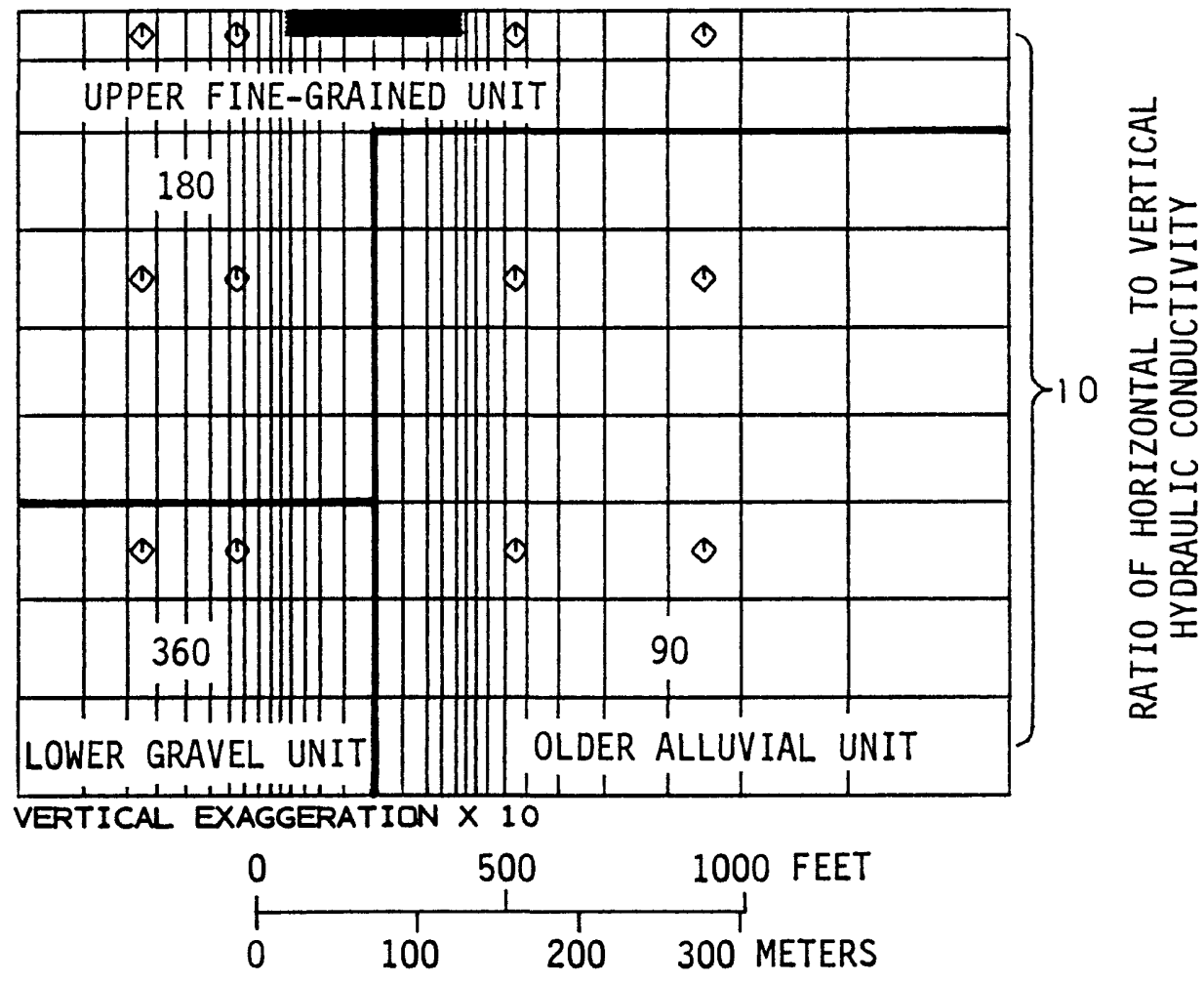

EXPLANATION

BLOCK IN ACTIVE PART OF FINITE-
DIFFERENCE GRID

RIVER LOCATION AS REPRESENTED IN

STEADY-STATE SIMULATIONS

$\diamond \quad$ PIEZOMETER LOCATION

180 HORIZONTAL HYDRAULIC CONDUCTIVITY

OF UNIT, IN FEET PER DAY

Figure 28.--Model dimensions and various hydraulic properties near piezometers for model of cross section 2. 


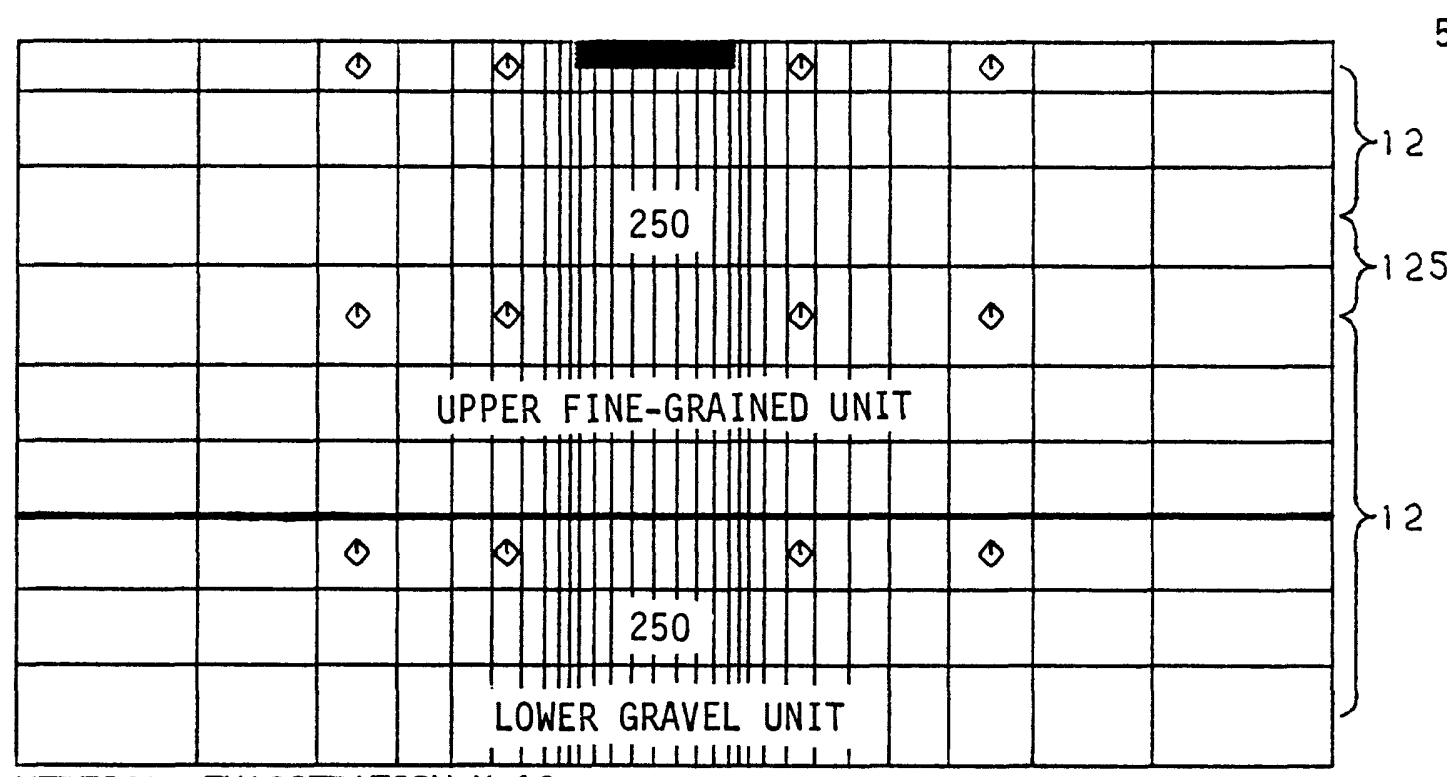

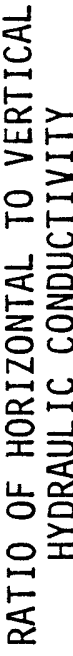

VERTICAL EXAGGERATION $\times 10$

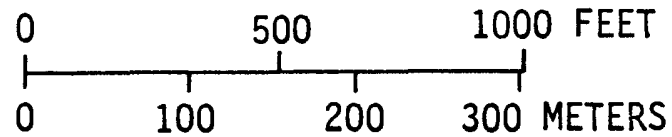

EXPLANATION

BLOCK IN ACTIVE PART OF FINITE-
DIFFERENCE GRID

RIVER LOCATION AS REPRESENTED IN STEADY-STATE SIMULATIONS

- PIEZOMETER LOCATION

HORIZONTAL HYDRAULIC CONDUCTIVITY

OF UNIT, IN FEET PER DAY

Figure 29.--Model dimensions and various hydraulic properties near piezometers for model of cross section 1 . 


\section{Calibration of the Models}

The model approximates the response of the real system to a stress. To calibrate each of the models, the aquifer was stressed by a river-stage change with time, and the resultant ground-water head changes were observed in the piezometers. The river-stage event was approximated in the model at each cross section, and the resultant head changes were computed for each piezometer location. By comparison between the observed and computed responses, one or more parameters could be changed and the model run again. This trial-and-error process was repeated until the model results satisfactorily approximated the observed results.

An additional calibration test usually performed concurrently with the transient procedure was to run the steady-state model and compare the modeled heads at the near-cluster piezometer locations with average annual heads determined from field data. If the differences were significant, one or more parameters were changed and the model was run again.

The trial-and-error calibration approach leads to somewhat subjective estimates of model parameters and computed return-flow rates. The reliability of the computed flow rates cannot be quantified. Statistically based techniques for formally estimating model parameters have been published in Cooley (1977); Neuman and Yakowitz (1979); and Yeh and Yoon (1981). Application of these techniques generally yields objective estimates of one or more model parameters with an assessment of the reliability of the estimated parameters. Preliminary return-flow rates computed using parameters derived by trial-and-error calibration, however, indicated values that were consistent with estimates made using surface-water-budget techniques. The additional insight to be gained by applying formal parameter-estimation techniques would not justify the additional research needed to apply such techniques at this time.

The parameters varied during the calibration process were (1) horizontal hydraulic conductivity of the upper fine-grained unit, (2) horizontal hydraulic conductivity of the older alluvium, (3) transmissivity of the gravel unit, (4) ratio of horizontal to vertical hydraulic conductivity, (5) initial storage coefficient, (6) specific storage value, and (7) inflow or outflow at the water table. A brief discussion of these parameters follows.

The upper fine-grained unit, the lower gravel unit, and the older alluvial unit typically consist of discontinuous layers of sediment of contrasting hydraulic conductivities. The lack of field data, however, precludes estimation of the thickness, areal distribution, and hydraulic conductivity of each layer. In calibrating the models, a single average horizontal hydraulic conductivity value was estimated for each unit. The thickness of the lower gravel unit is not known at most cross sections because test holes drilled for the project generally penetrated only to the top of the unit. Consequently, hydraulic-conductivity values estimated 
for the lower gravel unit are representative to the extent that the modeled thicknesses of this unit are representative. The significant hydraulic property in transmitting water horizontally in this unit is the product of the hydraulic conductivity and the thickness (transmissivity). Test simulations of a cross-sectional model confirmed that for varying thicknesses of the lower gravel unit, the results were essentially the same if the products of the thicknesses and hydraulic conductivities were the same.

The calibration procedure also included estimating an overall value of the ratio of horizontal to vertical hydraulic conductivity for the system. Geologists' logs from test holes at some of the cross sections indicate that clayey to silty layers are present over most of the width of the cross section. At some cross sections, data from piezometers indicate unusually large vertical head differences between two levels within a unit, thereby indicating a greater resistance to vertical flow between those levels than between other levels. The increased resistance to vertical flow in these cross sections was simulated by decreasing the vertical hydraulic conductivity between two rows of model nodes at the approximate level of the layer causing greater restriction to vertical flow.

The initial storage coefficient for transient simulations was varied to alter the general shapes of the response curves as they are affected by delayed yield (fig. 12). The selection of this parameter could affect the computation of return flow because the hydraulic-conductivity values selected in the trial-and-error calibration process could differ slightly with different values of this parameter. The values selected for the ratio of $S_{0} / S_{y}$ ranged from $1 / 26$ to $1 / 1$ with only two values less than $1 / 10$. Values in the range of $1 / 1$ to $1 / 10$ produce computed hydrographs at the far-cluster shallow piezometers of about the same magnitude but with slightly different response times (fig. 12). At most cross sections, use of the delayed-yield capability resulted in better agreement between observed and computed hydrograph shapes and response times. The differences between the magnitudes of the observed and computed hydrographs could be adjusted by changing values of other hydraulic parameters.

Estimates of storage properties of the aquifer are needed to estimate distributions of hydraulic conductivity. Specific yield of the aquifer is the storage property that has the most significant effect on the estimates of hydraulic conductivity. In general, an error in the specific-yield value used in transient simulations will result in the same percentage error in the estimated hydraulic-conductivity values. The specific yield of the aquifer was assumed to be known from the soilmoisture studies. Specific-yield values shown in table 1 were used in all the cross-sectional models except models of cross sections 14, 6, and 5, at which different values were estimated for each side of the river. For these cross sections, the average of the two estimated values was used in the model. Specific-yield values were not varied in the calibration process. 
The model program has the ability to simulate the effects of changes in storage because of compression and expansion of the water and aquifer. To simulate these effects, specific-storage values are input for all nodes below the water table. For test simulations, varying specific storage values from about $10^{-7}$ to $10^{-5} \mathrm{ft}^{-1}$ caused changes in the hydrographs on the order of several hundredths of a foot. It was therefore concluded that specific storage was not a significant parameter in the calibration of the models.

At several cross sections, some land between the far-cluster piezometers and the river is irrigated. At most of the cross sections, evapotranspiration loss may occur between the river and the far clusters. The evapotranspiration and infiltration may result in outflow from and inflow to the aquifer at the water table. Estimates of infiltration of irrigation water and loss of water through evapotranspiration could be input to a steady-state model as a volumetric rate per unit aquifersurface area for each of the water-table nodes. To test the significance of this flux on the steady-state calibration procedure, estimated recharge from irrigation was input for models of cross sections 16 and 7 . Additionally, evapotranspiration losses were input for some of the low-lying land adjacent to the river channel at cross section 7 . In both models, the flux to or from the surface of the aquifer made only slight differences in the computed steady-state heads at the shallow-piezometer locations. The net flow to the aquifer surface was at most 1 percent of the flow entering the cross section from beyond the far clusters. Inflow to or outflow from the aquifer at the water table was concluded to be insignificant in the calibration of the models and computation of return flows and therefore was not considered.

Several problems with the field data complicated the calibration procedure. One major problem was that during a river-stage event used for calibration, the river surface would occupy a substantially wider channel than was common at lower flows. At cross sections 12, 11, 10, and 9 , the high river stages caused flooding at or near one or more of the piezometer clusters. An attempt was made to simulate the change in the river width by adding or deleting specified-head nodes at different time steps; however, the width and position of the river surface at different times during the river-stage event could not be reliably determined. Although data were collected in the piezometers at and near flooded land, the reliability of the calibration using this data is questionable.

Another problem that affected the calibration was pumping wells near the piezometers. At cross section 12, a diesel-powered well pumping within one-quarter mile of the far cluster on the California side of the river caused head declines in piezometers on both sides of the river. With this well pumping, the gradients computed from the average annual heads in the piezometers on the California side were flat or away from the river. Data collected at this cross section were not considered to be representative of the conditions over the subreach. A similar problem 
occurred at cross section 6. A well was pumped within several hundred feet of the far cluster on the Arizona side and effects of pumping caused several feet of head decline in the deep piezometers on the Arizona side. Power records were available for the pumping well; therefore, the average annual heads were adjusted proportionally to the percentage of the time that the well was pumping and the average declines in the piezometers during pumping. This procedure provided estimates of the heads that would have been measured had the well not been pumping.

The finite-difference grids and the hydraulic-conductivity values estimated in the calibration procedure are shown in figures 13-29. Values given for hydraulic conductivity are those input to the models; the precision shown does not imply accuracy of the estimated values. Hydrographs showing observed and computed head changes are shown in figures 30-46. The average annual heads in the piezometers and the river are shown in table 2. Differences between the observed and computed heads for the near-cluster piezometers are shown in table 3 .

The graphical correlations shown in figures $30-46$ give an indication of the extent to which the model simulated the observed head changes caused by a pressure wave propagating normal to the river. Computed hydrographs that differ significantly in shape or magnitude from the observed probably are indicative of small-scale spatial variations of aquifer characteristics that could not be defined.

Similarly, the differences between observed and computed average annual heads (table 3 ) give an indication of the extent to which the models simulated the average annual head distributions between the far clusters and the river. Differences in table 3 that are large percentages of the corresponding differences between heads in the far-cluster piezometers and the river (table 2) probably are indicative of an inability to define small-scale spatial variations of aquifer characteristics.

\section{RESULTS}

\section{Computation of Return Flow}

The steady-state model computes rates of flow entering or leaving the aquifer from each block on the far-cluster boundaries. The net flow to the river from each side is normally computed as the total flow entering the aquifer from eash far-cluster boundary. At a few of the cross sections, however, part of the flow entering from a far-cluster boundary does not discharge to the river but rather crosses the opposite far-cluster boundary. Flow crossing under the river results in part from layers that restrict vertical flow. This flow component is most significant at cross section 14 where as much as 45 percent of the flow that enters 


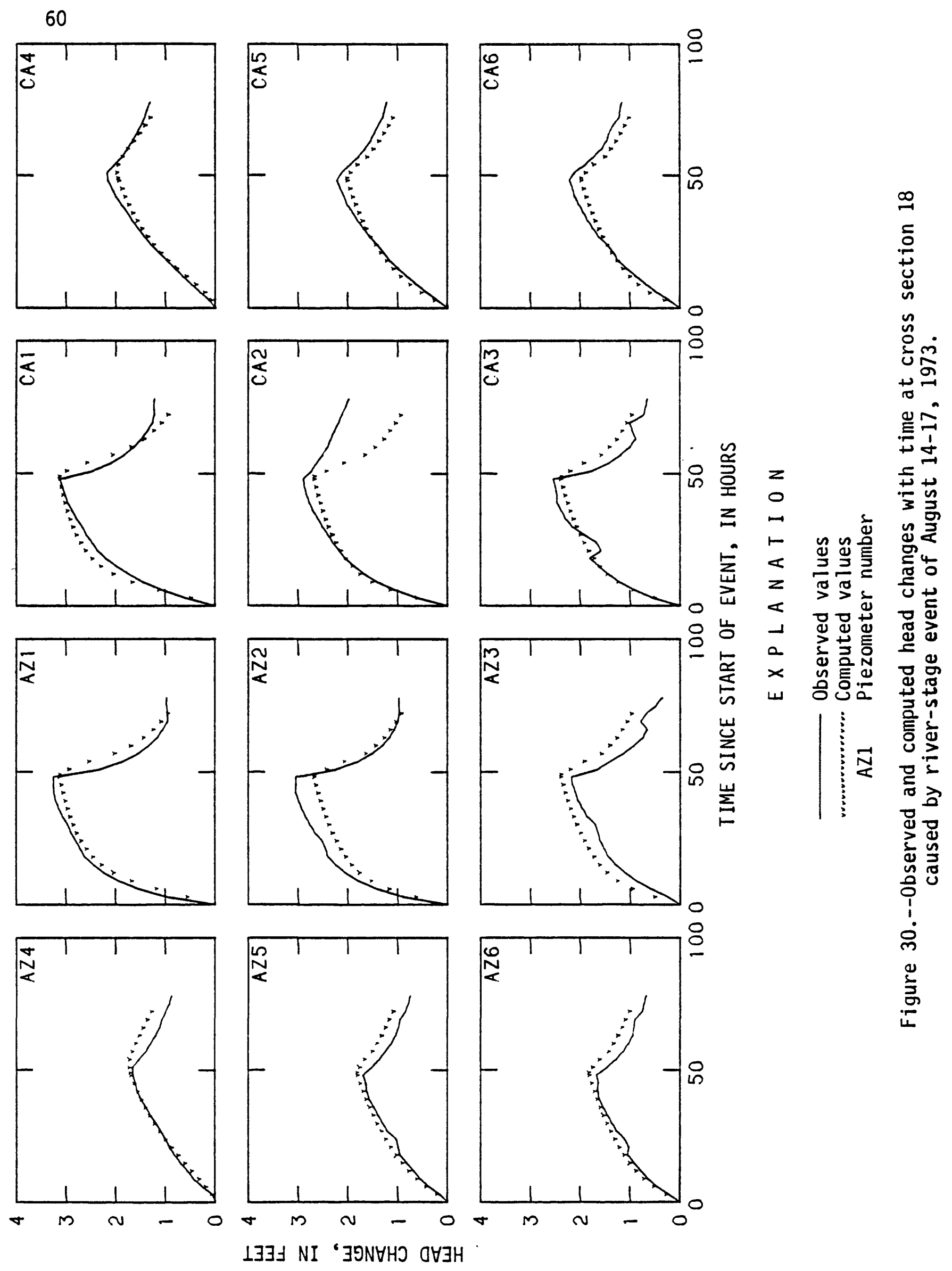



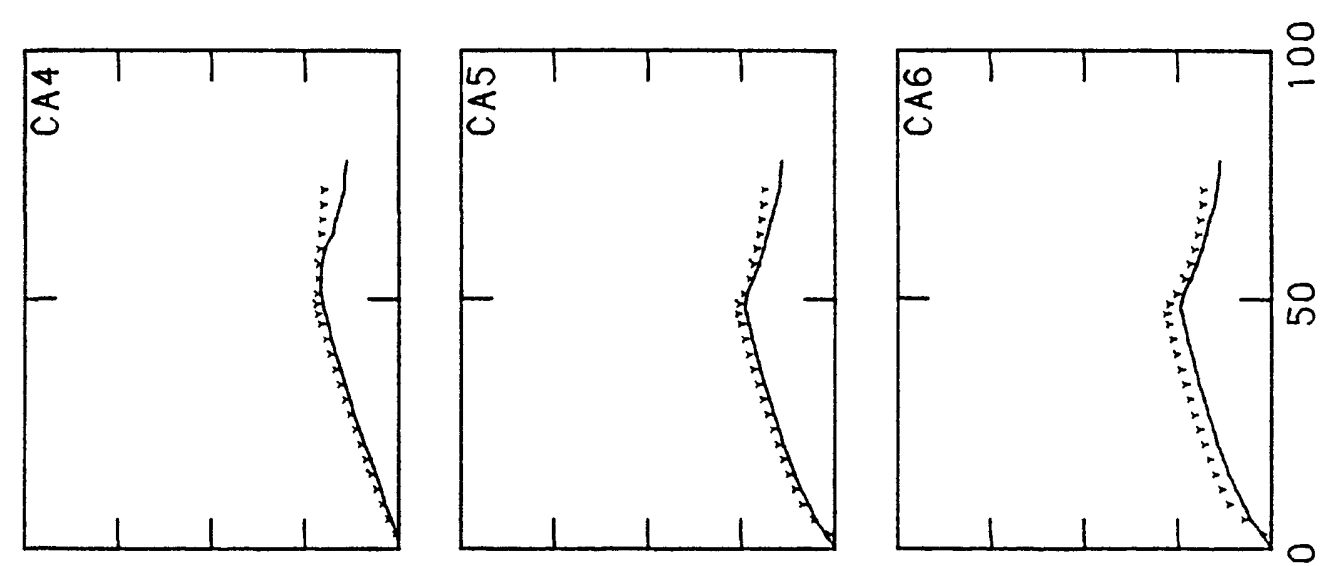

61
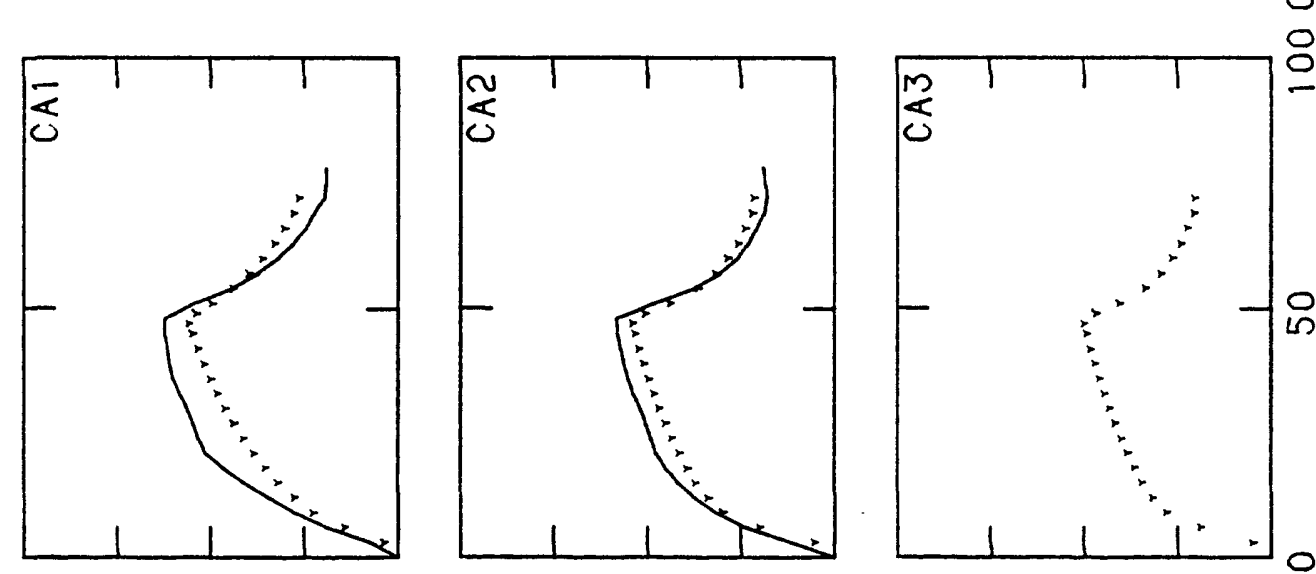

응

.

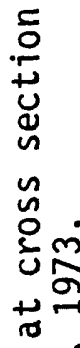

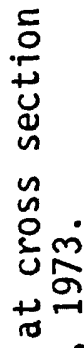
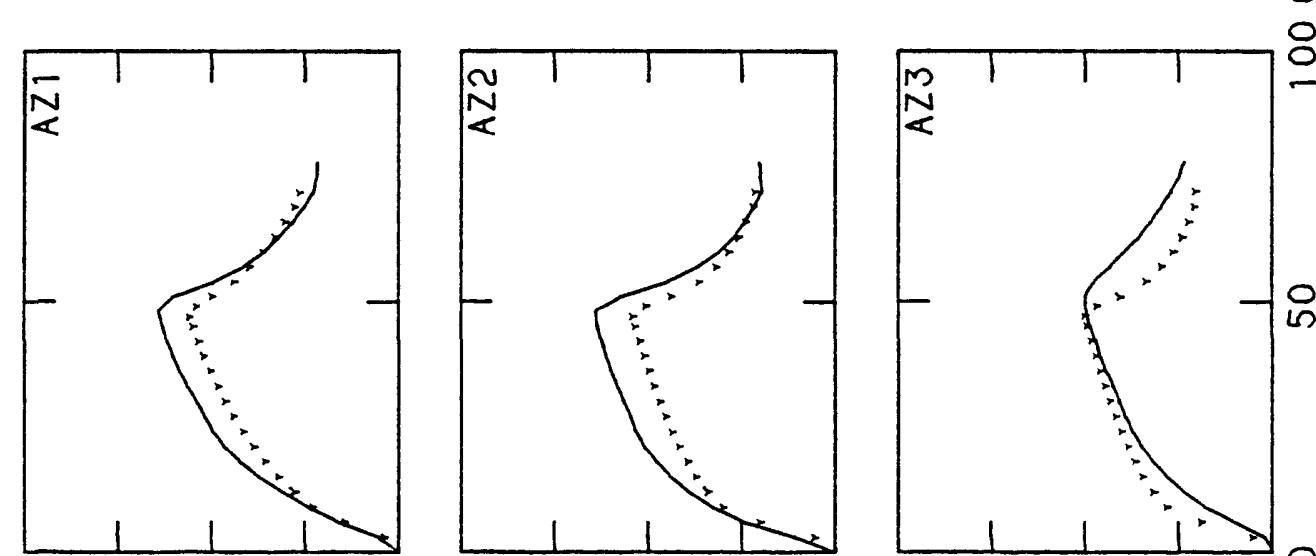

年

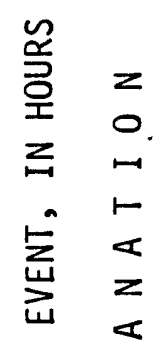

궁

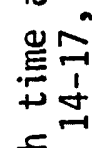

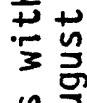

ป ڤ

孚

$\mathrm{E}_{4}$

空。

岩

จ

व

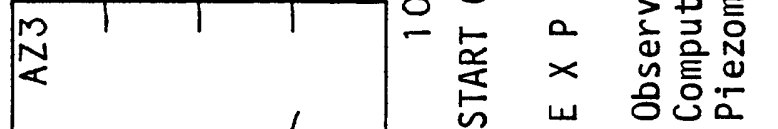

\%

马ृ乛̃

$\exists$ in

है

$\stackrel{\pi}{\gtrless}$
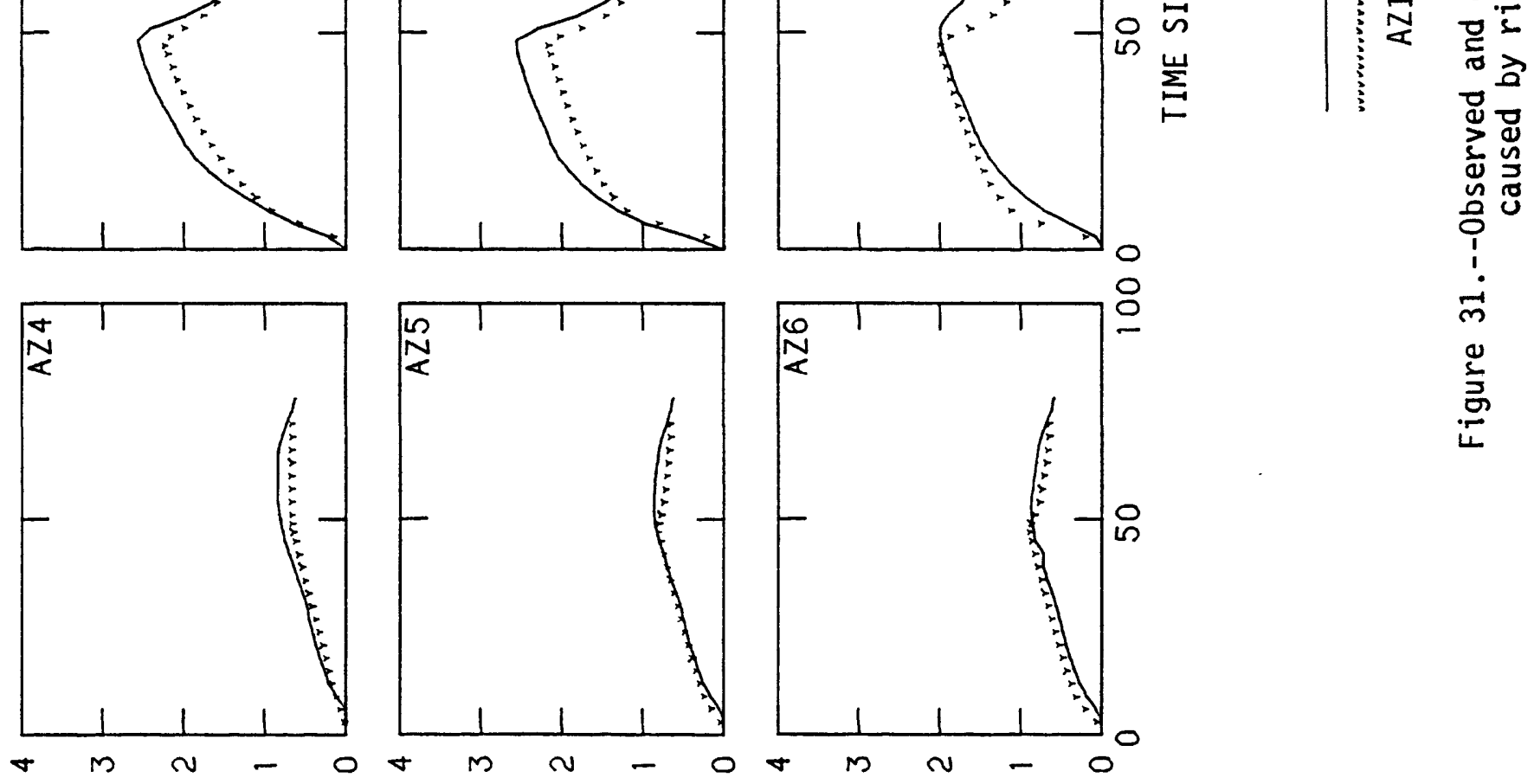

,

悤 


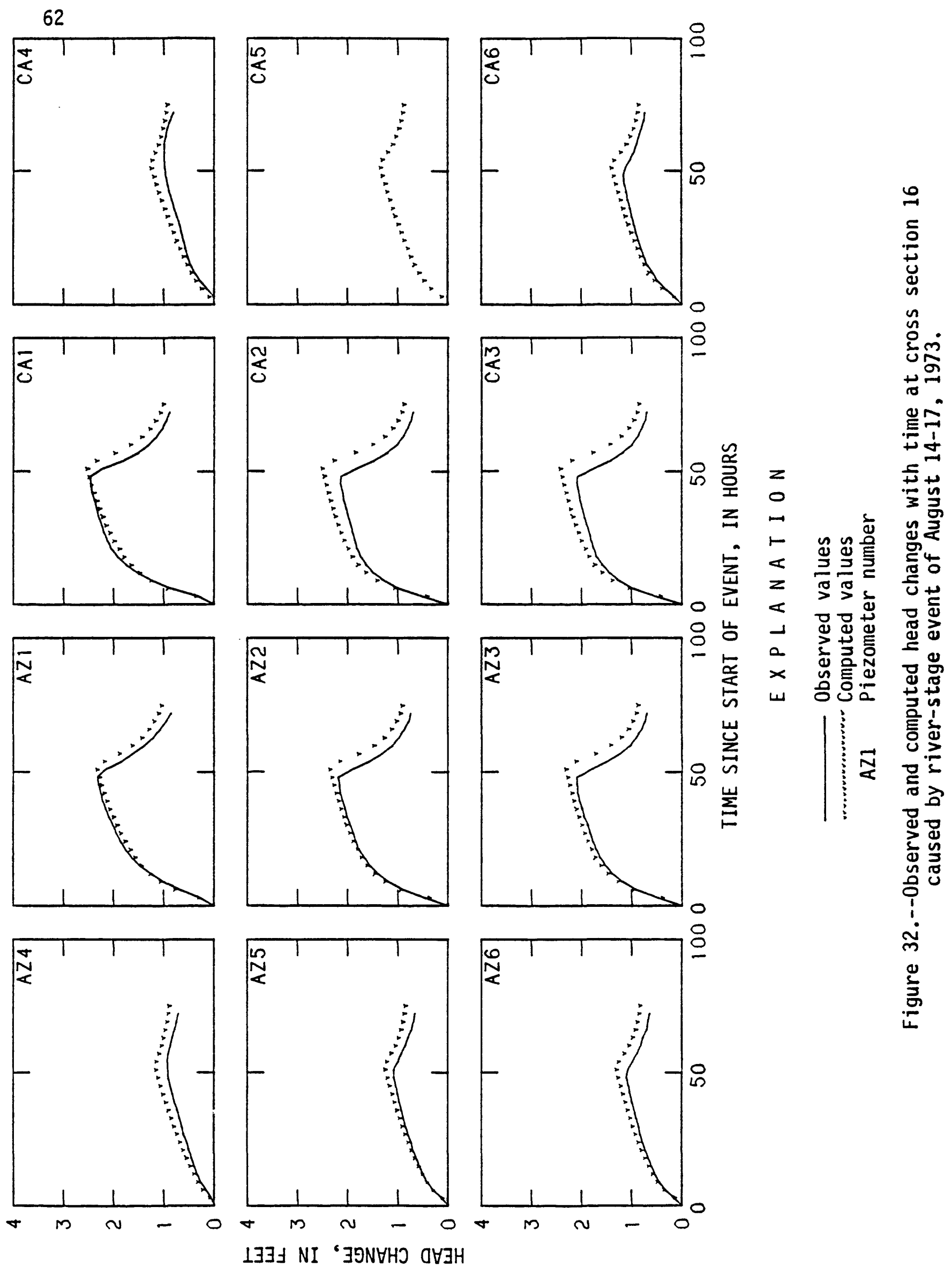




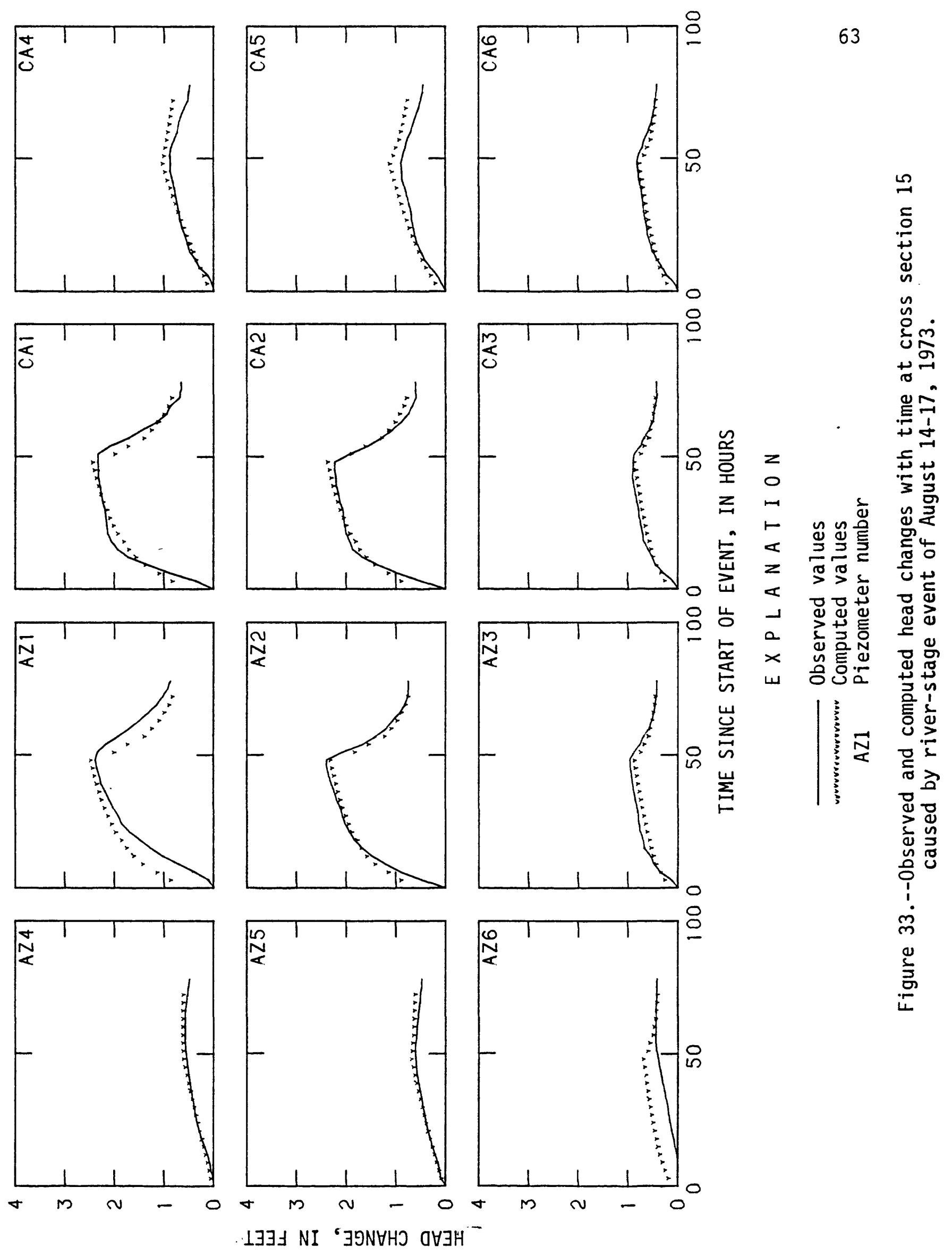




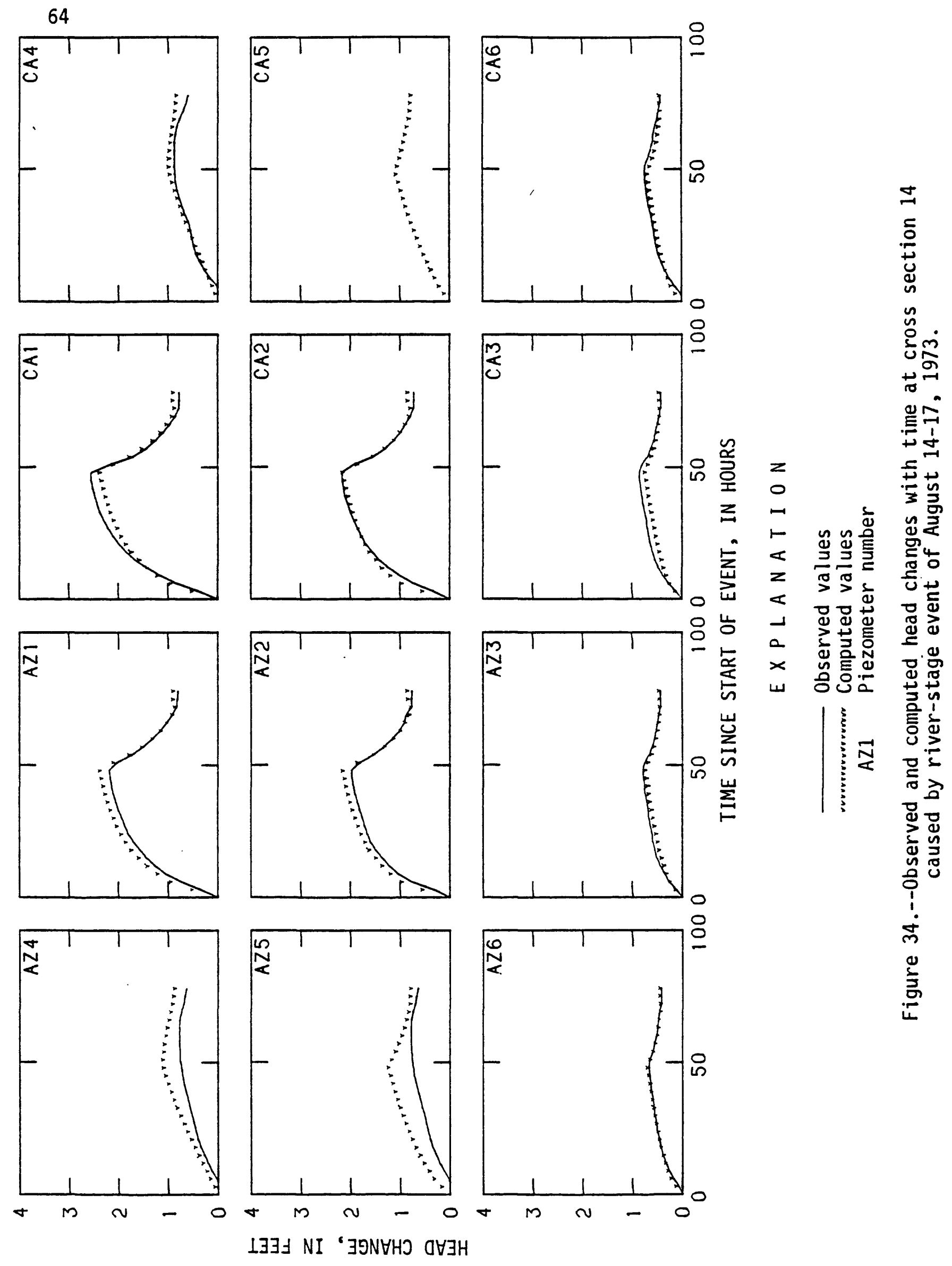




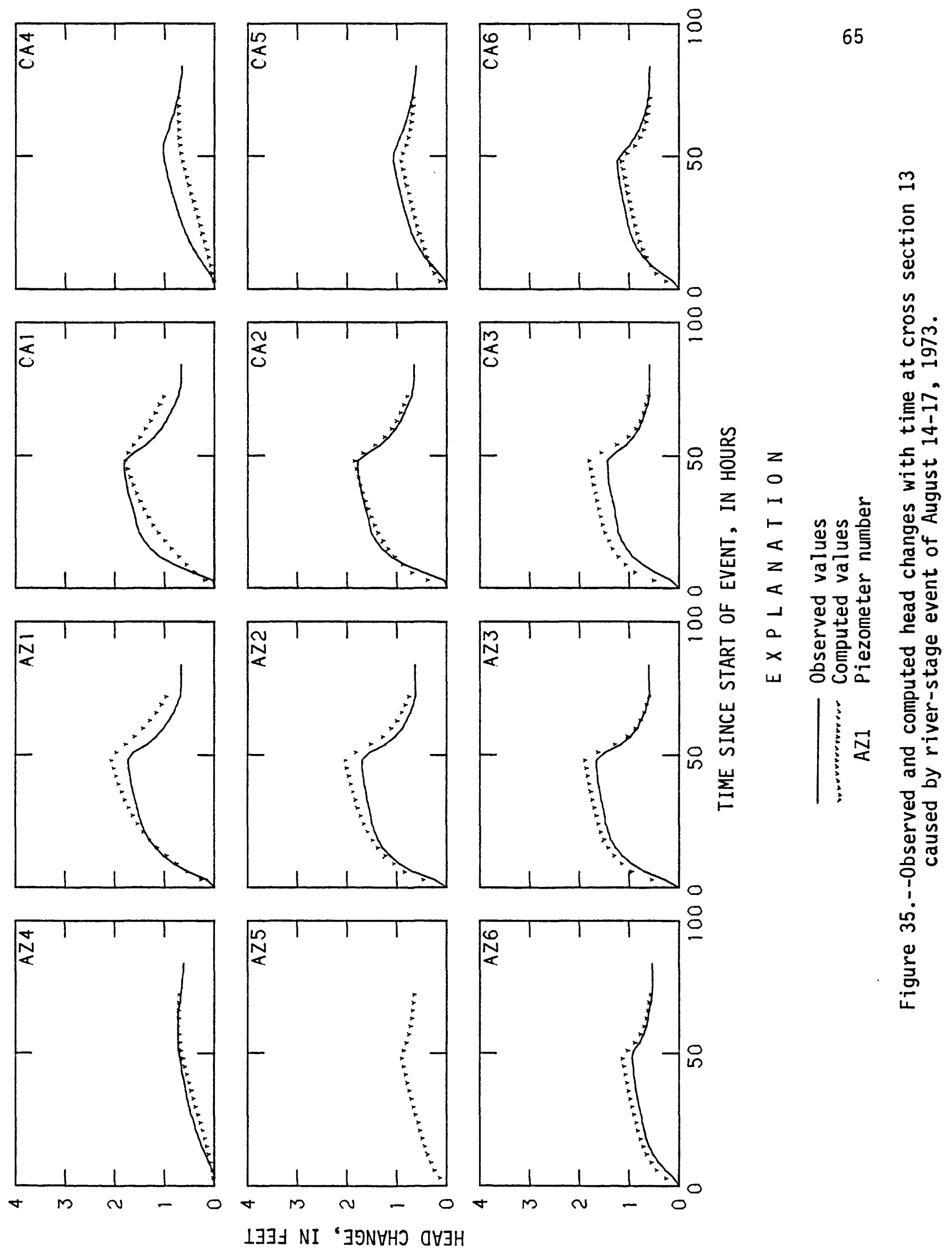




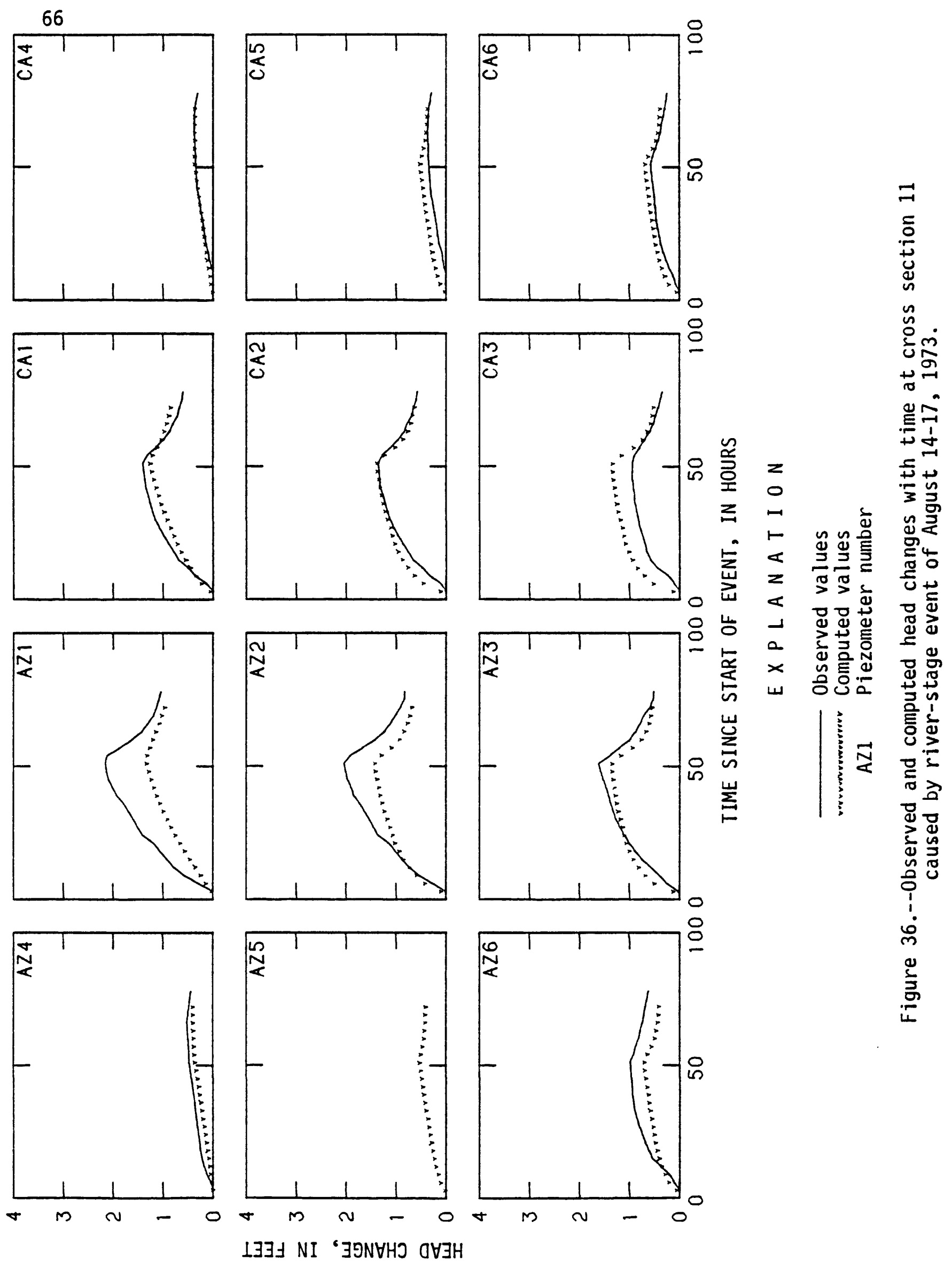




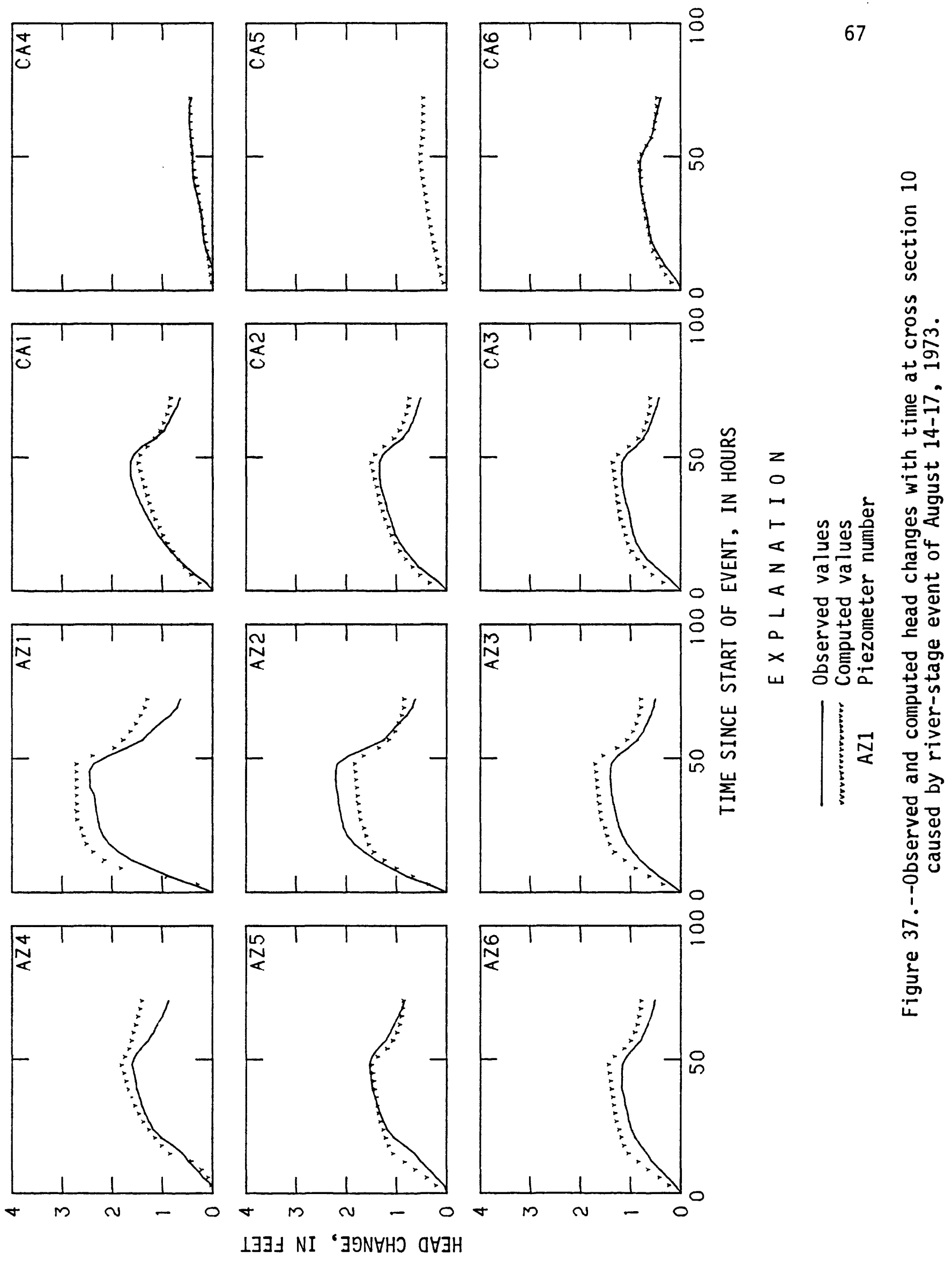




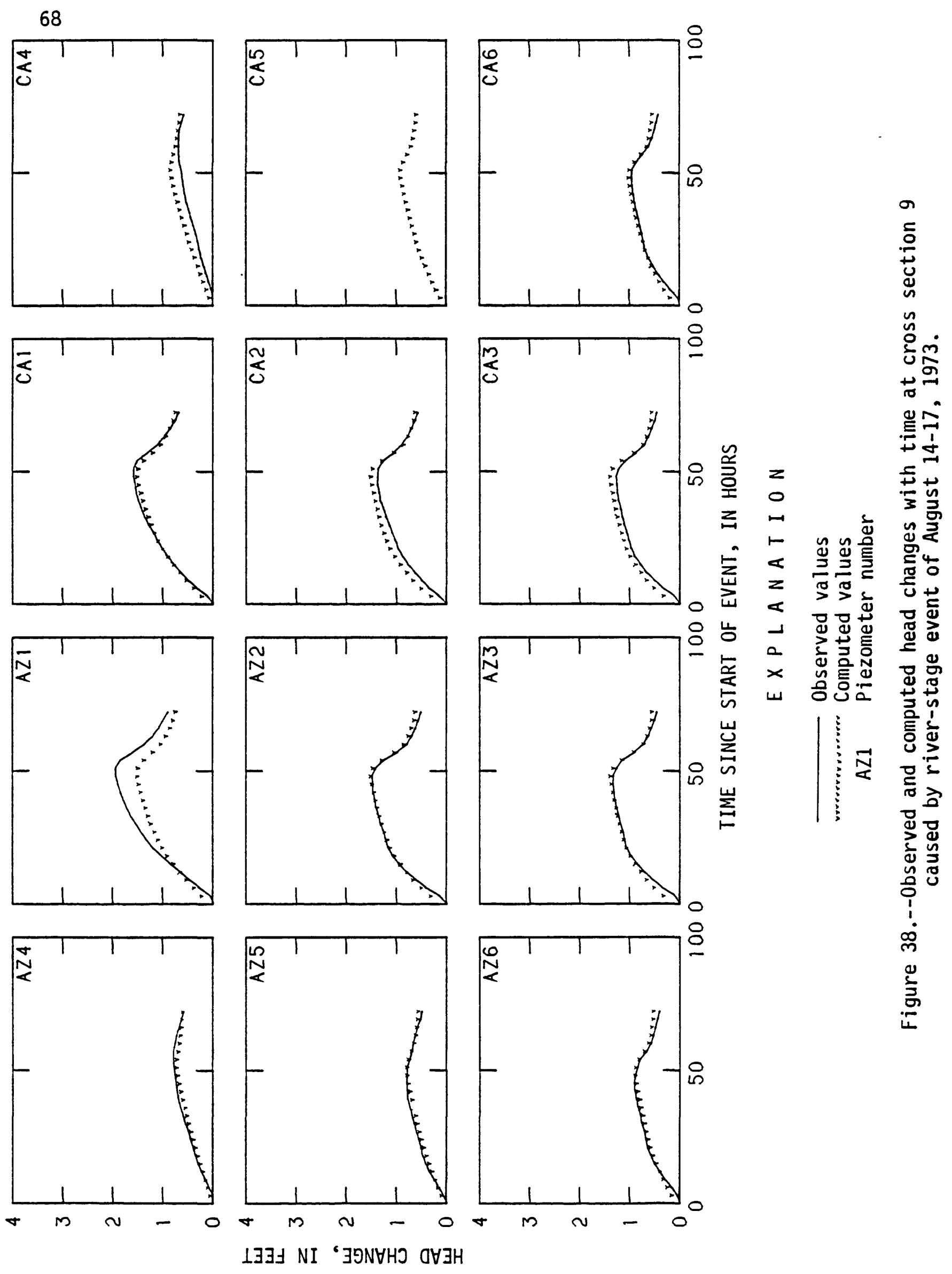




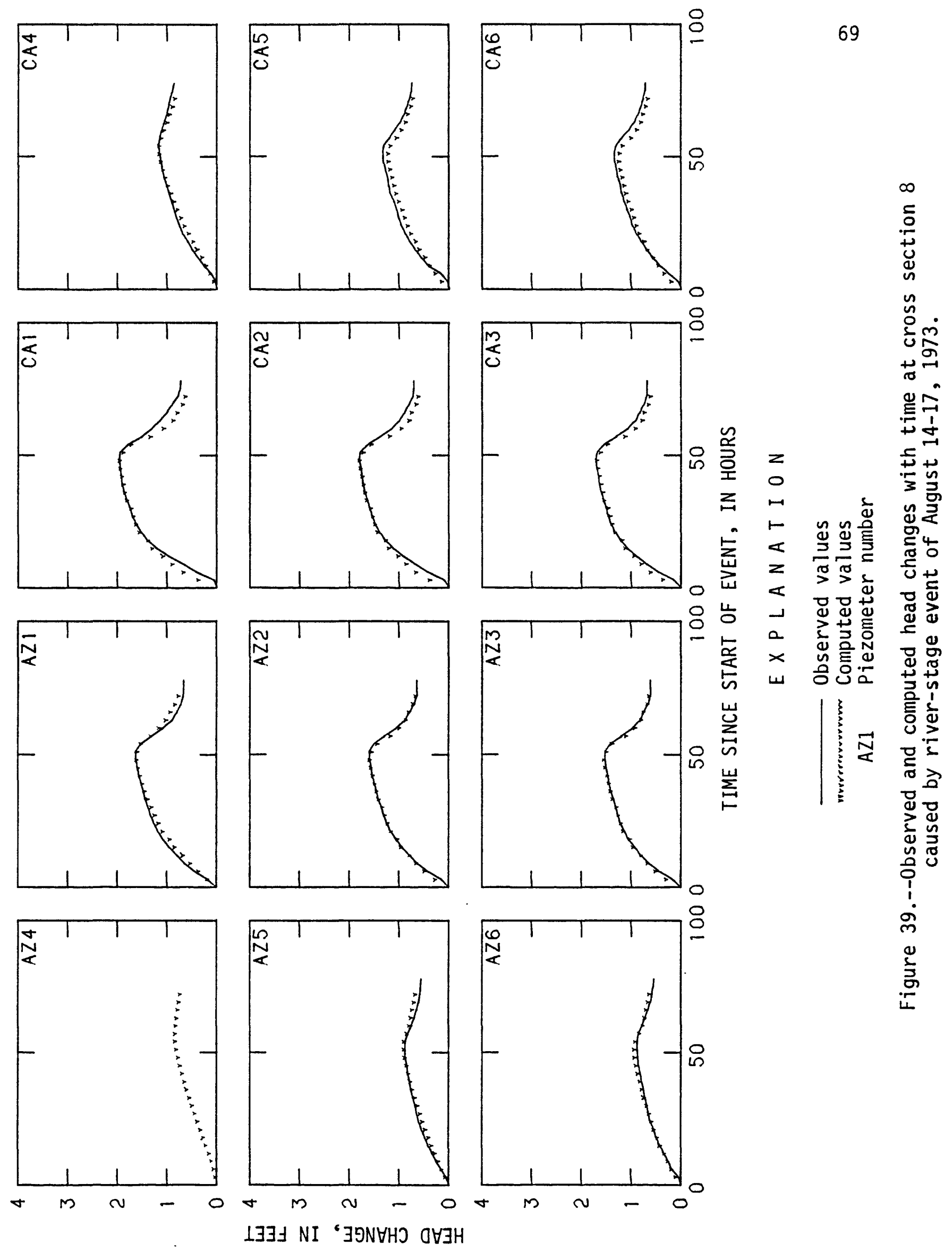




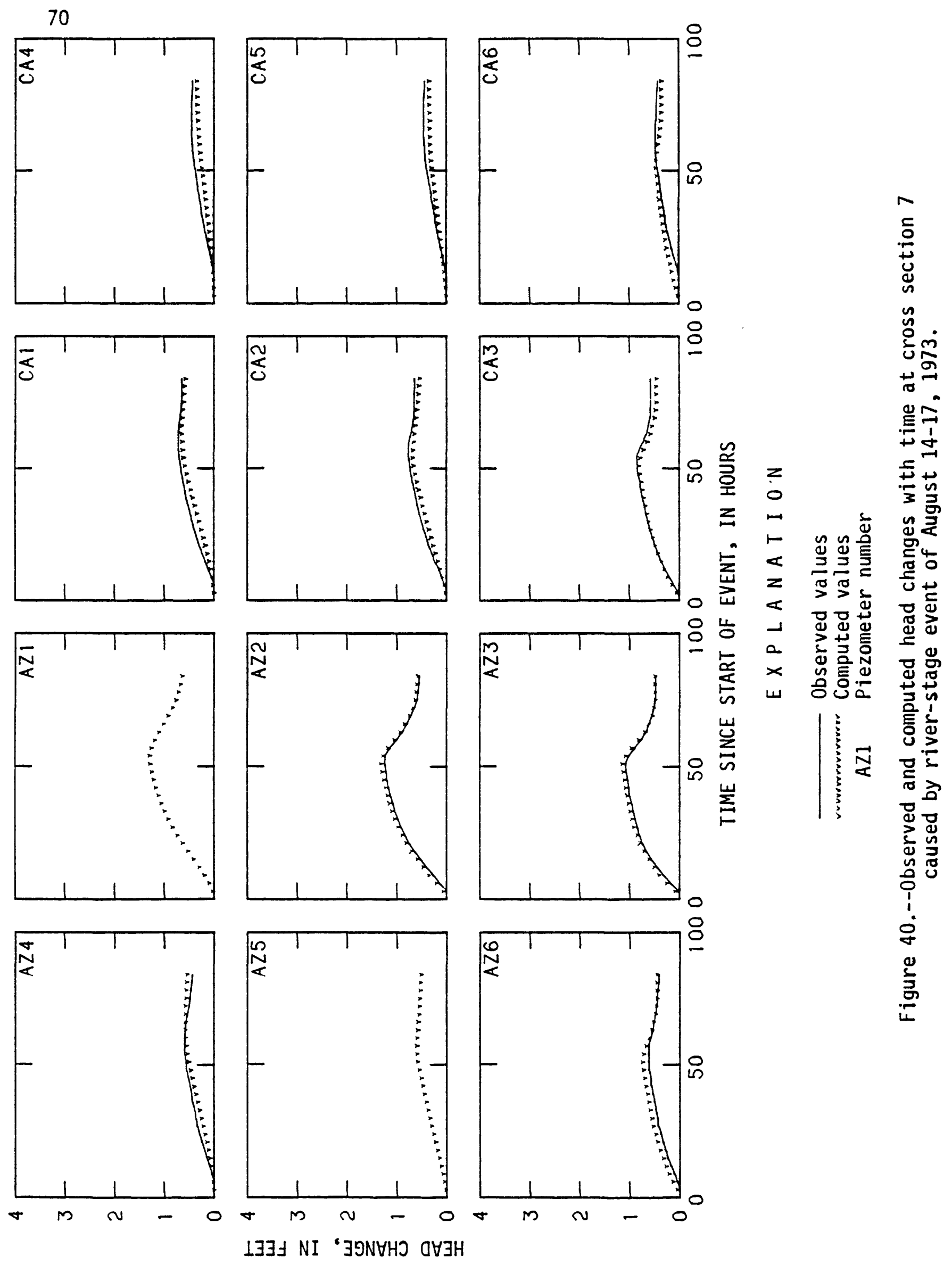




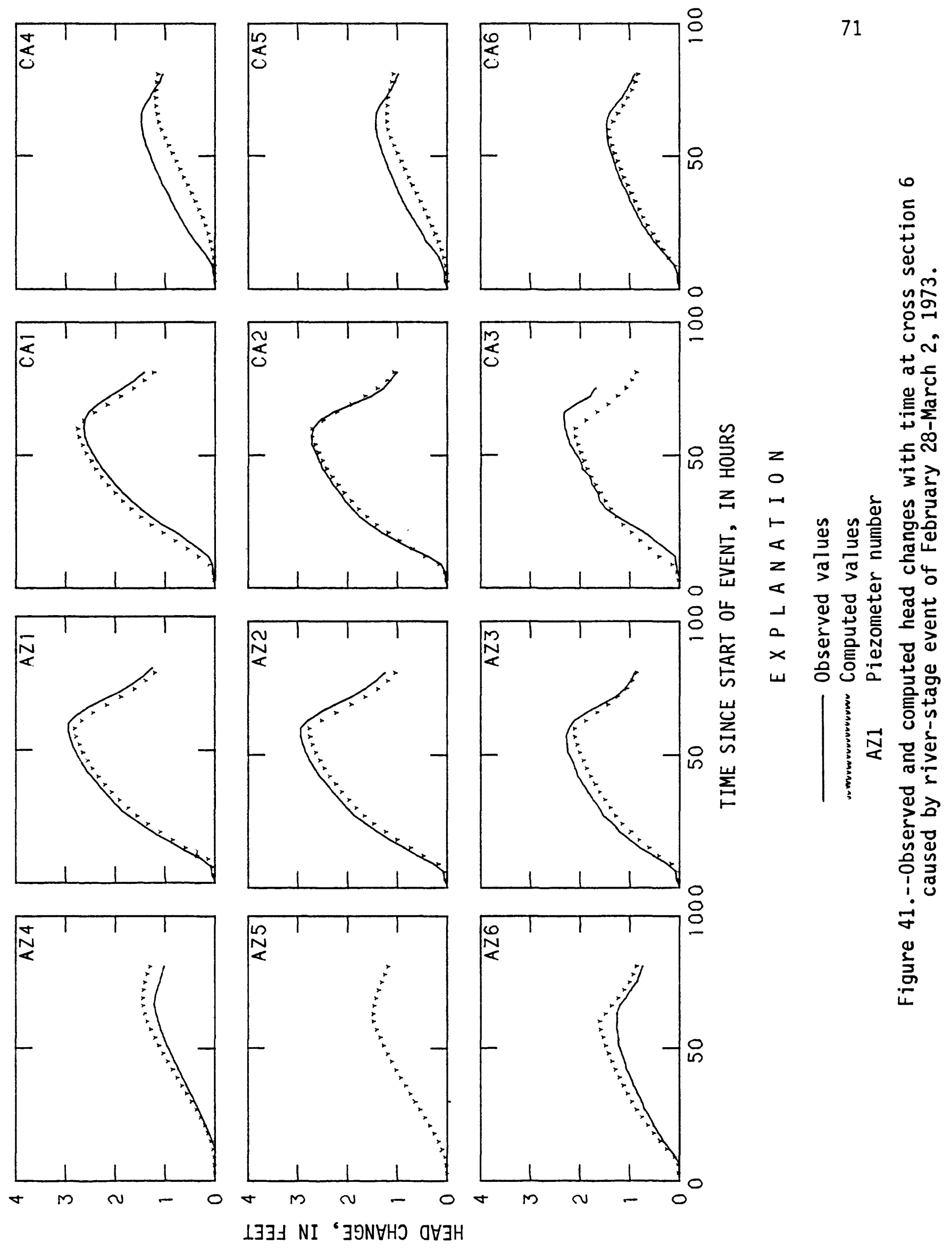




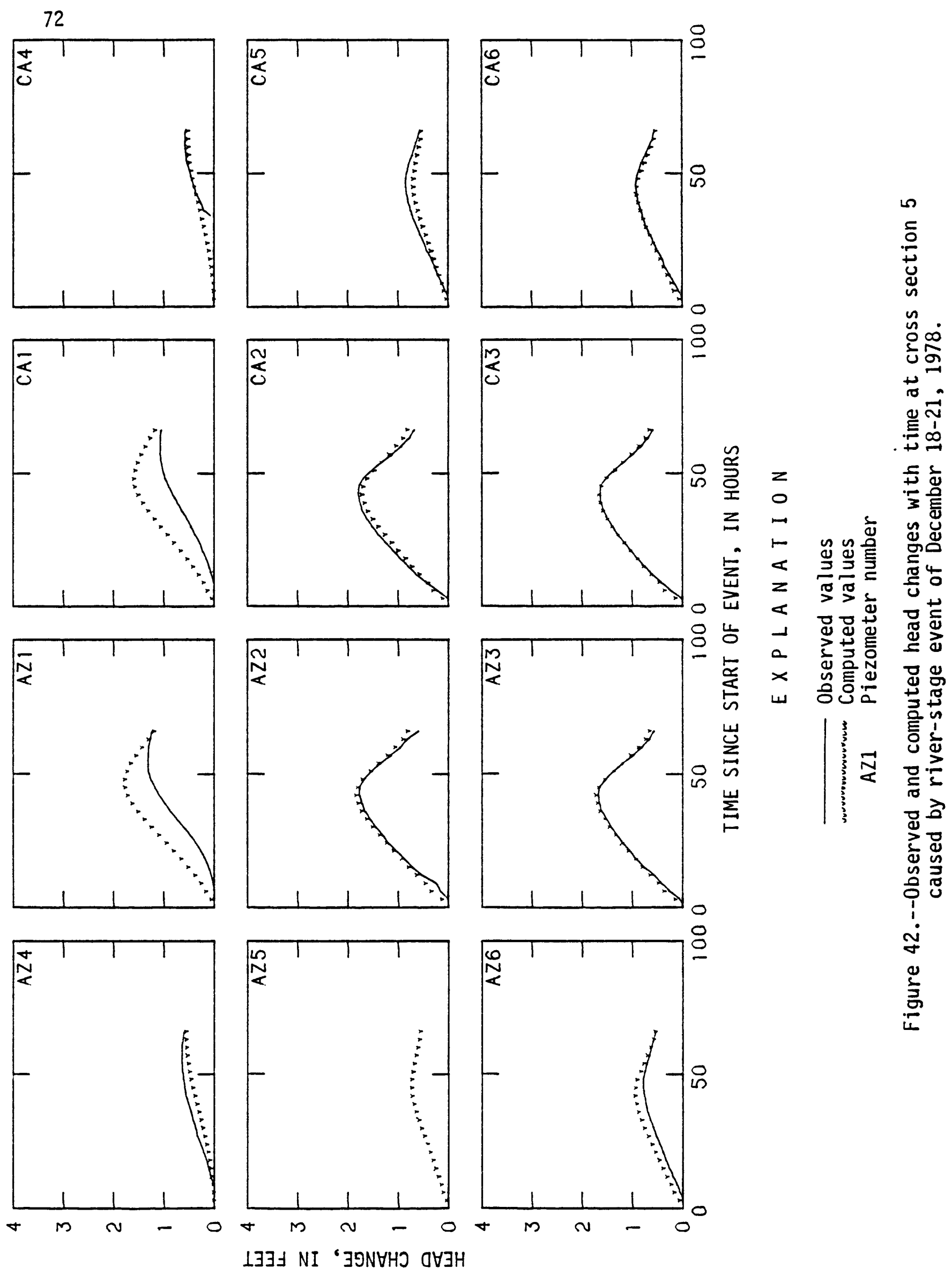




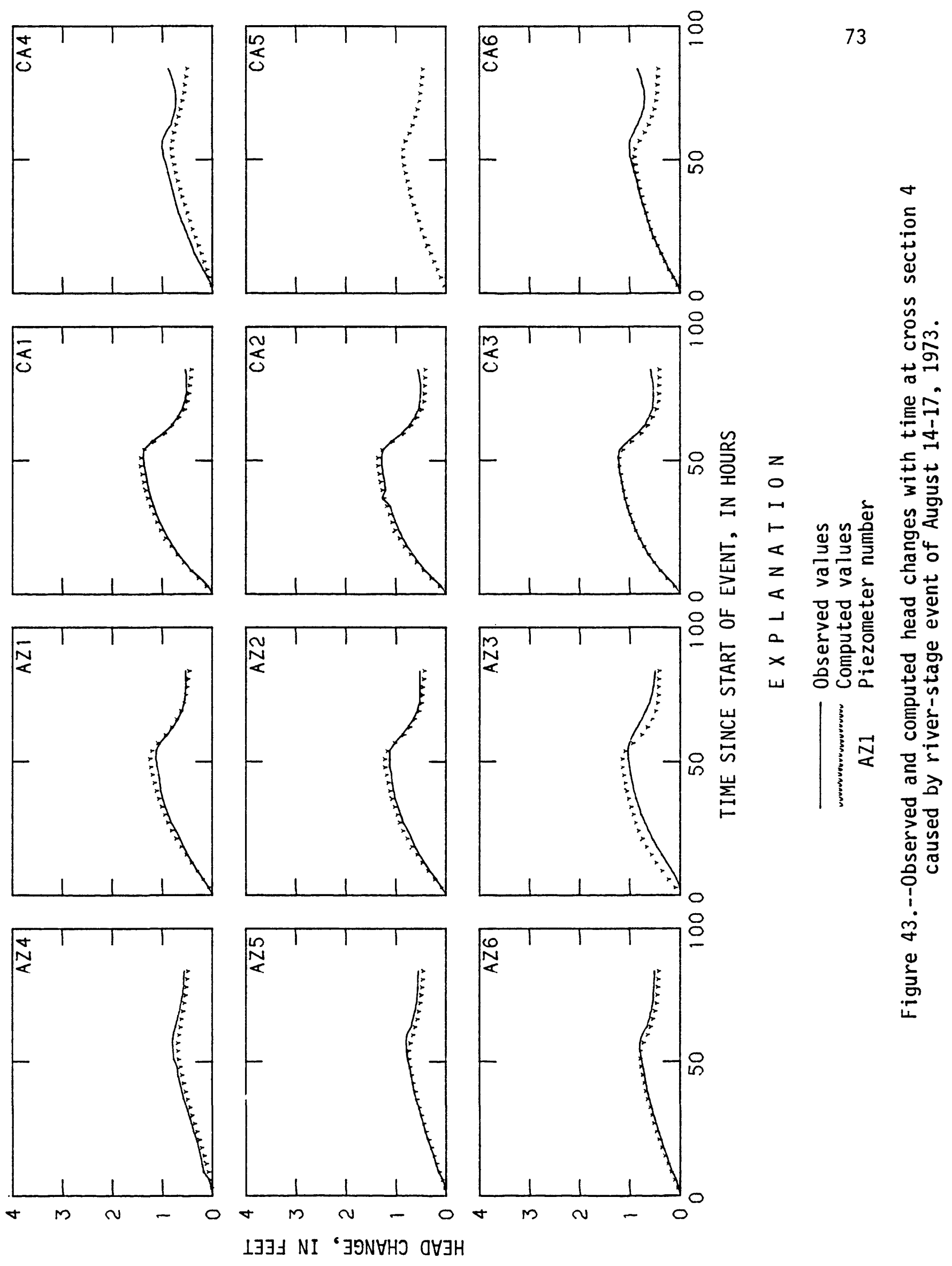




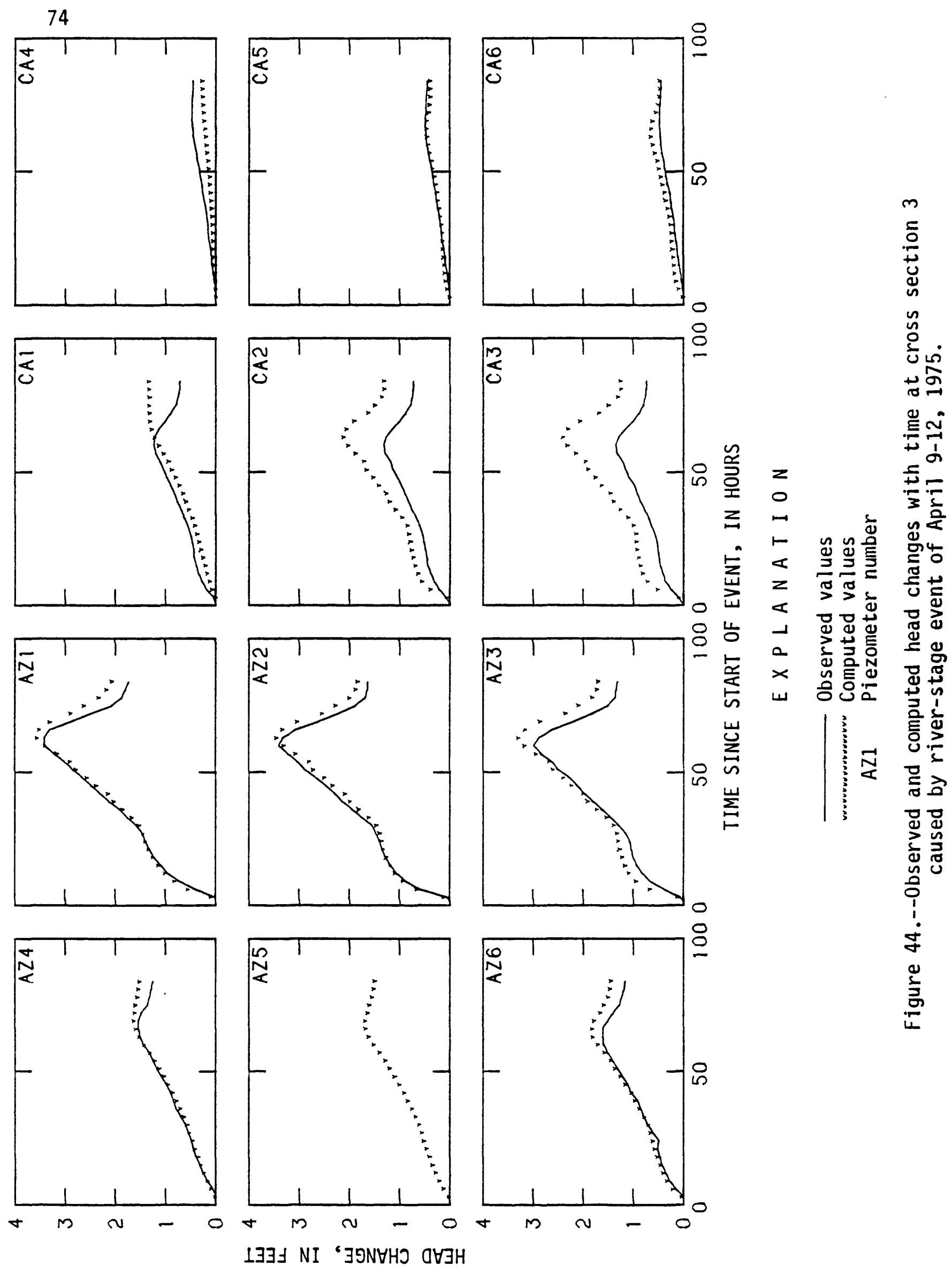




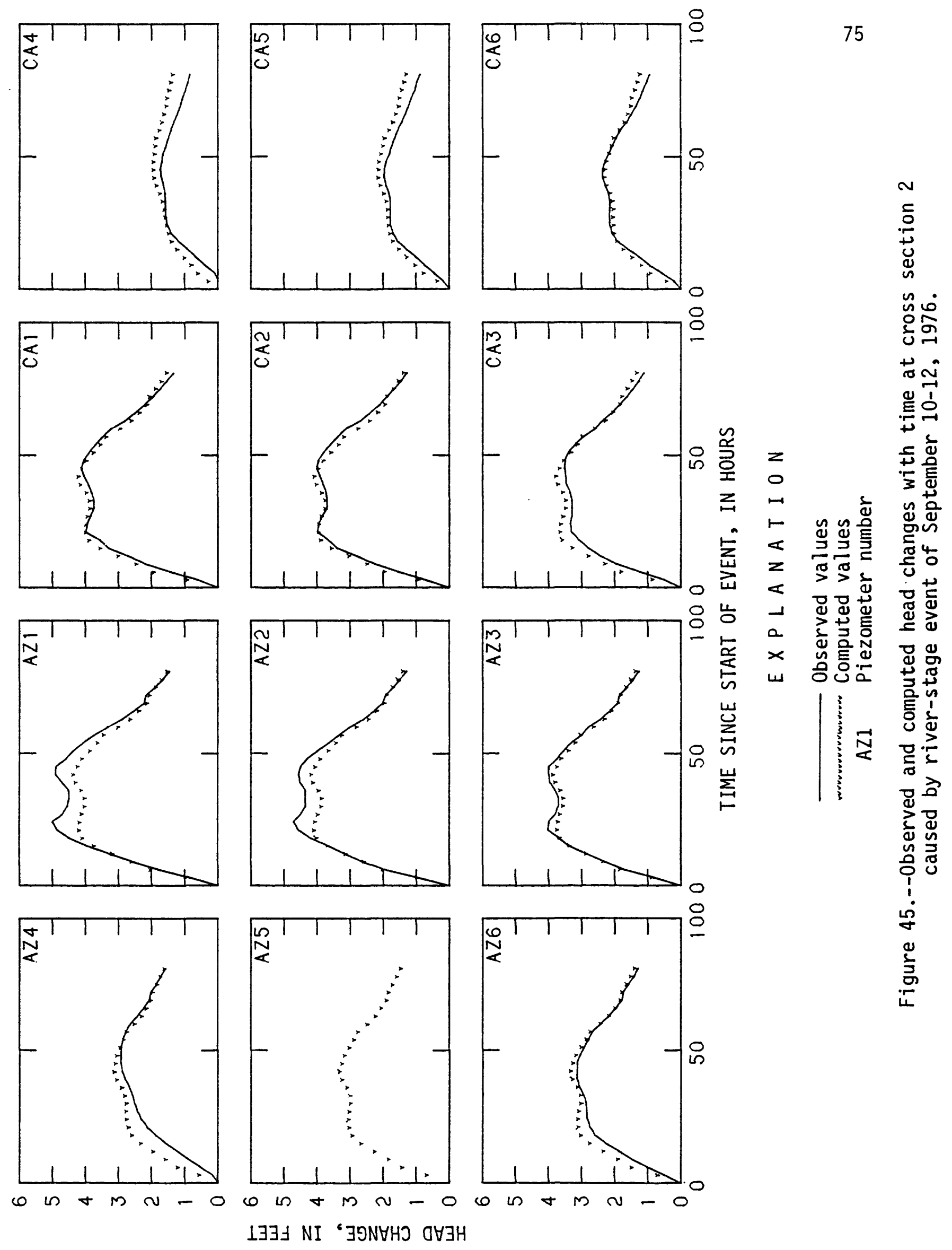




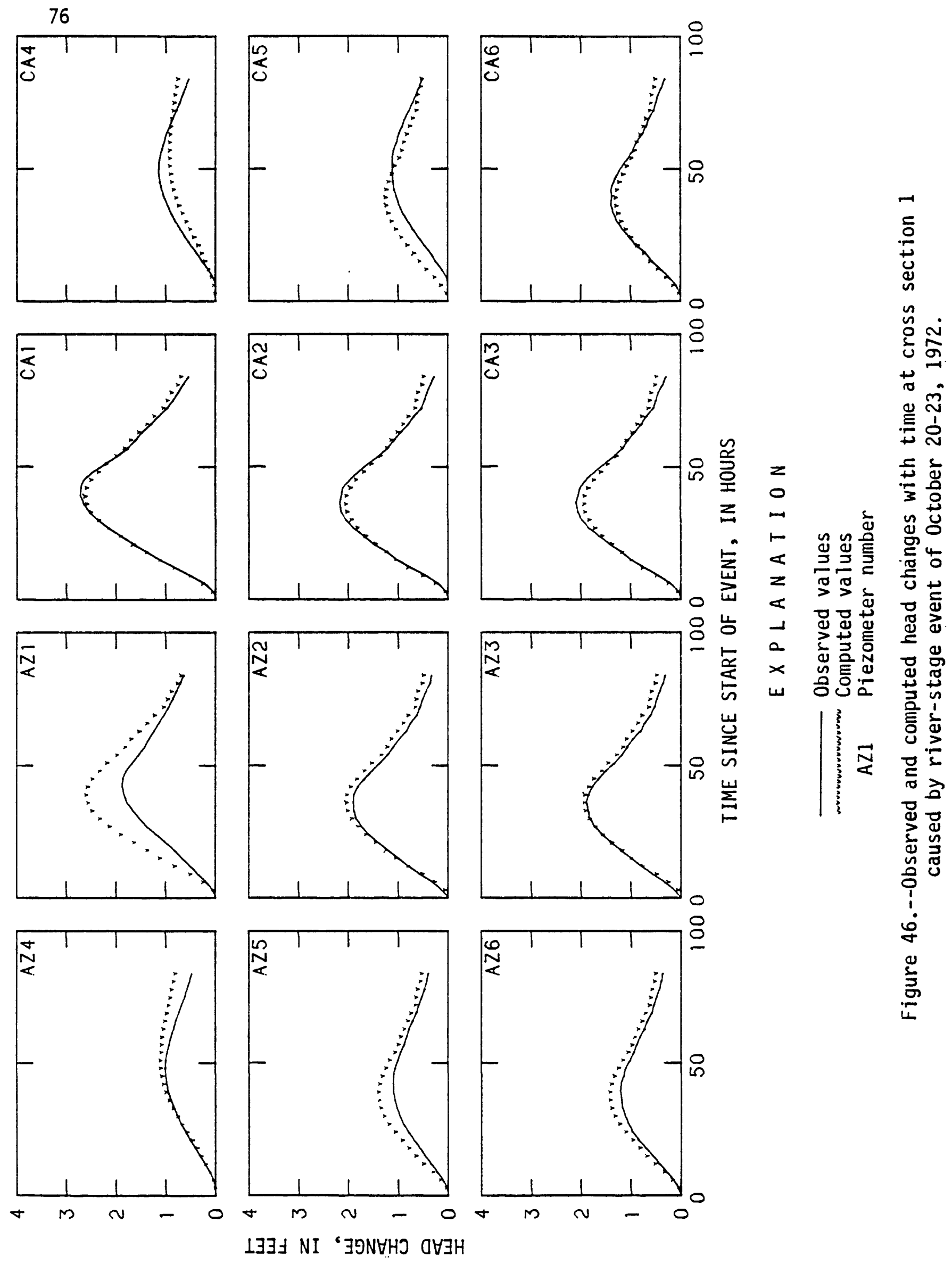


Table 2.--Average annual heads measured in piezometers in the Yuma area

[Values are in feet above National Geodetic Vertical Datum of 1929]

\begin{tabular}{|c|c|c|c|c|c|c|c|c|c|c|c|c|c|}
\hline \multirow[b]{2}{*}{ Year } & \multicolumn{6}{|c|}{ Piezometer number } & \multirow{2}{*}{$\begin{array}{l}\text { River } \\
\text { surface }\end{array}$} & \multicolumn{6}{|c|}{ Piezoneter number } \\
\hline & AZ1 & AZ2 & $\overline{A Z 3}$ & A24 & A25 & AZ6 & & CAl & $\mathrm{CA} 2$ & CA3 & CA4 & CA5 & CAB \\
\hline
\end{tabular}

Cross section 18

$\begin{array}{lllllllll}1974 & 124.53 & 124.77 & 125.05 & 125.33 & 125.35 & 125.46 & 124.22 & 124.42\end{array}$

1975

1976

1977

1978

$\begin{array}{llll}124.49 & 124.65 \quad 124.95 \quad 125\end{array}$

$\begin{array}{llll}124.45 & 124.67 & 124.94 & 125\end{array}$

$124.02 \quad 124.26$

$123.78 \quad 123.94$

$124.51 \quad 124.84$

125.28

$\begin{array}{lll}125.34 & 124.10 & 124.33\end{array}$

125.27

124.01124 .35

$\begin{array}{llll}124.74 & 124.90 & 123.72 & 123.83\end{array}$

124.44
1975

1976

1977

1978

1973

1974

1975

1976

1977

1978

1974

1975

1976

1977

1978

1974

1975

1976

1977

1978

1974

1975

1976

1977

1978

1974

1975

1976

1977

1978

1974

1975

1976

1977

1978 $\begin{array}{llllllll}123.80 & 123.81 & 124.02 & 124.77 & 124.87 & 124.91 & 122.78 & 123.73\end{array}$

$\begin{array}{lllllllll}123.83 & 123.84 & 124.17 & 124.72 & 124.80 & 124.86 & 122.72 & 123.76\end{array}$

$\begin{array}{lllllllll}123.80 & 123.81 & 124.09 & 124.79 & 124.88 & 124.94 & 122.60 & 123.75\end{array}$

123.64123 .63

$123.49 \quad 123.50$

$124.03 \quad 124.55$

$124.66 \quad 124.79$

124.58

$123.44 \quad 123.57$

$123.50 \quad 123.62$

$123.32 \quad 123.41$

$123.18 \quad 123.37$

$123.06 \quad 123.26$

$123.18 \quad 123.34$

$123.34 \quad 123.43$

$123.10 \quad 123.20$

$122.99 \quad 123.09$

$122.60 \quad 122.70$

$122.41 \quad 122.51$

$123.65 \quad 124.05$

123.27

123.00

$\begin{array}{lll}122.65 & 123.04 & 124.88\end{array}$

$122.32 \quad 122.72$

$123.65 \quad 123.79$

123.35

123.01

122.76

122.36

$119.26 \quad 119.28$

$119.22 \quad 119.48$

$119.19 \quad 119.44$

$119.02 \quad 119.31$

$118.72 \quad 118.95$

$\begin{array}{llll}117.60 & 117.72 \quad 117.92 \quad 118.01\end{array}$

$\begin{array}{lllll}117.88 & 118.04 & 118.38 & 118.51\end{array}$

$\begin{array}{llll}117.82 & 117.90 & 118.15\end{array}$

$\begin{array}{llll}117.57 & 117.73 \quad 118.09\end{array}$

118.18

118.13

$\begin{array}{llll}117.24 & 117.45 \quad 117.85\end{array}$

124.45

124.48

124.29

124.25

124.30

125.71

125.46

125.42

124.82

124.65

125.59

125.06

124.81

124.49

124.10

124.52

$124.54 \quad 124.61122 .40$

124.42

124.34

124.27

124.31

$122.20 \quad 122.91$

$\begin{array}{llll}124.56 & 121.99 & 122.84\end{array}$

$\begin{array}{lll}124.36 & 121.92 & 122.74\end{array}$

$\begin{array}{llll}124.45 & 121.79 \quad 122.80\end{array}$ Cross section 15

$\begin{array}{llll}125.73 & 125.86 & 122.35 & 123.49\end{array}$

$\begin{array}{llll}125.47 & 125.58 & 122.13 & 123.23\end{array}$

125.43

121.92

123.02

124.84

$121.68 \quad 122.59$

$\begin{array}{llll}124.88 & 121.71 & 122.36\end{array}$ Cross section 14

$125.60 \quad 126.47 \quad 122.30 \quad 123$.

$\begin{array}{llll}125.08 & 125.97 & 122.05 & 122.62\end{array}$

$\begin{array}{llll}124.80 & 125.75 & 121.85 & 122.55\end{array}$

$\begin{array}{llll}124.50 & 125.33 & 121.61 & 122.22\end{array}$

$\begin{array}{llll}124.10 & 124.95 & 121.61 & 121.97\end{array}$

Cross section 13

$\begin{array}{llllll}24.61 & 124.65 & 124.73 & 121.73 & 123.04\end{array}$

124.08

124.11

$124.17 \quad 121.55$

123.91

$\begin{array}{lll}124.01 & 121.03 \quad 122.51\end{array}$

$\begin{array}{lll}123.30 & 120.97 \quad 122.29\end{array}$

\section{Cross section 11 \\ 119.34}

$119.63 \quad 119.15 \quad 119.50$

$\begin{array}{llll}119.82 & 120.18 & 118.75 & 119.53\end{array}$

$\begin{array}{lllll}119.73 & 119.92 & 118.63 & 119.2\end{array}$

$119.31 \quad 118.30 \quad 118.86$ Cross section 10
124.43

125.06

$\begin{array}{llllllll}25.09 & 121.93 & 123.24 & 123.20 & 123.42 & 123.22 & 123.30 & 123.41\end{array}$

122.67

122.94

122.73

123.13

122.79

$\begin{array}{lll}123.01 & 123.07 \quad 123.10\end{array}$

$122.44 \quad 122.59$

122.05

$119.46 \quad 119.53$

$\begin{array}{lllllll}119.60 & 119.84 & 118.88 & 119.42 & 119.44 & 119.52\end{array}$

119.55

119.63

$119.23 \quad 119.64$

$122.75 \quad 122.76 \quad 122.80$

$122.40 \quad 122.51 \quad 122.53$

$\begin{array}{lllllllll}118.04 & 118.13 & 117.44 & 117.52 & 117.67 & 117.83 & 117.58 & 117.87 & 117.94\end{array}$ $\begin{array}{llllllllll}118.52 & 118.62 & 117.42 & 117.69 & 118.03 & 118.20 & 118.01 & 118.07 & 118.22\end{array}$ $\begin{array}{llllllllll}118.19 & 118.29 & 117.40 & 117.59 & 117.91 & 118.06 & 117.92 & 118.04 & 118.08\end{array}$ $\begin{array}{lllllllll}118.14 & 118.25 & 116.96 & 117.35 & 117.70 & 117.95 & 117.77 & 117.82 & 117.85\end{array}$ $\begin{array}{llllllllll}117.72 & 117.87 & 116.81 & 117.12 & 117.16 & 117.41 & 117.22 & 117.27 & 117.39\end{array}$ 
Table 2.--Average annual heads measured in piezometers in the Yuma area-Continued

\begin{tabular}{|c|c|c|c|c|c|c|c|c|c|c|c|c|c|}
\hline \multirow[b]{2}{*}{ Year } & \multicolumn{6}{|c|}{ Piezometer number } & \multirow{2}{*}{$\begin{array}{l}\text { River } \\
\text { surface }\end{array}$} & \multicolumn{6}{|c|}{ Piezometer number } \\
\hline & $A Z 1$ & AZ2 & $A Z 3$ & Al4 & A75 & AZ6 & & CAI & $\mathrm{CA} 2$ & CA3 & CA4 & CA5 & CAB \\
\hline & \multicolumn{13}{|c|}{ Cross section 9} \\
\hline 1974 & 115.29 & 115.32 & 115.34 & 115.65 & 115.67 & 115.74 & 115.21 & 115.28 & 115.28 & 115.31 & 115.33 & 115.32 & 115.32 \\
\hline 1975 & 5.46 & 5.58 & 115.61 & 116.02 & 116.06 & 116.23 & 115 & 115.50 & 115.55 & 115.65 & 115. & 15.65 & 15.72 \\
\hline 1976 & 5.61 & 115.80 & 115.90 & 116.28 & 116.31 & 116.49 & 115.34 & 115.58 & 115.81 & 115.88 & 115.86 & 115.91 & 16.01 \\
\hline 1977 & 5.22 & 115.49 & 115.60 & 115.97 & 116.02 & 116.20 & 114.98 & 115.29 & 115.45 & 115.62 & 115.52 & 115.59 & 15.72 \\
\hline 1978 & 115.29 & 115.50 & 115.60 & 115.84 & 115.93 & $\begin{array}{r}116.13 \\
\text { Cros }\end{array}$ & $\begin{array}{l}115.03 \\
5 \text { section }\end{array}$ & $\begin{array}{l}115.38 \\
n 8\end{array}$ & 115.52 & 115.66 & 115.73 & 115.77 & 115.84 \\
\hline 1973 & 113.60 & 113.68 & 113.77 & 114.20 & 114.22 & 114.23 & 113.22 & 113.26 & 113.39 & 113.46 & 113.44 & 113.49 & 113.50 \\
\hline 1974 & 3.51 & 113.58 & 113.68 & 114.21 & 114.22 & 114.24 & 113.00 & 113.07 & 113.19 & 113.25 & 113.20 & 113.28 & 113.29 \\
\hline 1975 & 13.76 & 113.90 & 114.04 & 114.77 & 114.81 & 114.85 & 113 & 113.34 & 113.45 & 113.53 & 113.51 & 113.53 & 113.64 \\
\hline 1976 & 3.56 & 113.69 & 113.79 & 114.29 & 114.31 & 114.33 & 113 & 113.16 & 113.26 & 113.34 & 113.31 & 113.41 & 113.43 \\
\hline 1977 & 13.49 & 113.57 & 113.70 & 114.09 & 114.08 & 114.16 & 112.94 & 112.98 & 113.09 & 113.17 & 113.09 & 112.98 & 113.48 \\
\hline 1978 & 113.27 & 113.33 & 113.48 & 113.83 & 113.80 & $\begin{array}{r}113.86 \\
\text { Cros }\end{array}$ & $\begin{array}{r}112 \\
5 \mathrm{se}\end{array}$ & $\begin{array}{l}112.90 \\
n 7\end{array}$ & 113.02 & 113.10 & 113.01 & 113.13 & 113.15 \\
\hline 1975 & 12.49 & 112.48 & 112.91 & 113.06 & 113.20 & 113.21 & 111.84 & 113.29 & 113.28 & 113. & 113. & 113.82 & 113.96 \\
\hline 1976 & 2.49 & 12.54 & 112.93 & 113.04 & 113.26 & 113.27 & & 113.25 & 113.26 & 113 & 113 & 113.86 & 13.95 \\
\hline 1977 & 2.20 & 12.24 & 112.57 & 112.73 & 112.92 & 112.93 & & 112.85 & 112.87 & 112 & 113 & 113.38 & 113.43 \\
\hline 1978 & 12.24 & 112.31 & 112.60 & 112.68 & 112.87 & $\begin{array}{r}112.88 \\
\text { Cros }\end{array}$ & & $\begin{array}{l}112.80 \\
n 6\end{array}$ & 112.79 & 112.88 & 113.38 & 113.32 & 113.39 \\
\hline 1975 & 111.24 & 111.17 & 111.66 & 111.77 & 111.82 & 111.98 & 110. & 111.33 & 111.38 & 111.74 & & 112.53 & 112.59 \\
\hline 1976 & 1.06 & 111.20 & 111.90 & 112.10 & 112.15 & 112.23 & & 111.38 & 111.46 & 111.80 & 112.48 & 112.58 & 112.76 \\
\hline 1977 & 10.77 & 110.94 & 111.58 & 111.70 & 111.80 & 112.10 & 109 & 111.10 & 111.18 & 111. & 112.05 & 112.15 & 112.31 \\
\hline 1978 & 110.80 & 110.89 & 111.40 & 111.43 & 111.55 & $\begin{array}{r}111.91 \\
\text { Cros }\end{array}$ & 109.85 & $\begin{array}{l}111.07 \\
n 5\end{array}$ & 111.18 & 111.57 & 112.08 & 112.16 & 112.32 \\
\hline 1975 & 9.83 & 110.01 & 110.22 & 110. & 110.88 & 110.89 & 108. & 110.09 & 110.35 & & & & 111.79 \\
\hline 1976 & 9.90 & 110.10 & 110.32 & 110.80 & 110.96 & 110.97 & & 110.13 & 110.38 & 110.67 & 111.25 & 111.63 & 111.75 \\
\hline 1977 & 109.64 & 109.83 & 110.06 & 110.50 & 110.631 & 010.64 & 108 & 109.99 & 110.16 & 110.42 & 110.99 & 111.38 & 111.45 \\
\hline 1978 & 109.63 & 109.80 & 110.03 & 110.41 & 110.56 & $\begin{array}{r}110.57 \\
\text { Cros }\end{array}$ & 108 & $\begin{array}{l}109.76 \\
n 4\end{array}$ & 110.02 & 110.34 & 110.72 & 111.16 & 111.29 \\
\hline 1975 & .64 & 8.62 & & & .14 & 109.10 & 107.38 & 108.76 & 9.00 & & & 09.83 & 109.88 \\
\hline 1976 & 8.90 & 8.87 & 109.25 & 109. & 109.36 & 109.39 & & & 109.32 & & & 110.19 & 110.22 \\
\hline 1977 & 08.86 & 108.82 & 109.19 & 109.38 & 109.33 & 109.36 & 107.46 & 108.82 & 109.13 & 109.27 & 109.76 & 109.90 & 109.95 \\
\hline 1978 & 108.90 & 108.83 & 109.14 & 109.38 & 109.34 & $\begin{array}{r}109.37 \\
\text { Cros }\end{array}$ & $\begin{array}{r}107.40 \\
5 \text { sectio }\end{array}$ & 108.75 & 109.13 & 109.24 & 109.69 & 109.81 & 109.86 \\
\hline 1975 & 06.65 & 107.04 & 107.43 & 107.98 & 108.20 & 108.54 & 105.97 & 109.21 & 109.04 & 109.16 & & 112.32 & 112.33 \\
\hline 1976 & 107.08 & 107.42 & 107.86 & 108.26 & 108.48 & 108.76 & & & 109.37 & 109.42 & 112.68 & 112.72 & 112.72 \\
\hline 1977 & 17.16 & 107.49 & 107.90 & 108.33 & 108.56 & 108.91 & 106 & 109.32 & 109.22 & 109.28 & 112.06 & 112.10 & 112.13 \\
\hline 1978 & 106.99 & 107.33 & 107.73 & 108.14 & 108.47 & $\begin{array}{r}108.73 \\
\text { Cros }\end{array}$ & 106.25 & $\begin{array}{l}109.19 \\
n 2\end{array}$ & 109.08 & 109.14 & 111.87 & 111.90 & 111.89 \\
\hline 1975 & 5.24 & 105.45 & 105.72 & 105. & 105.79 & 105.91 & 105.05 & 105.67 & 105.76 & & & 107.25 & 107.85 \\
\hline 1976 & 05.59 & 105.78 & & & 106.10 & 106.21 & & & 105.89 & & 107.24 & 107.37 & 107.89 \\
\hline 1977 & 105.87 & 106.04 & 106.37 & 106.26 & 106.33 & 106.49 & 105 & 106.18 & 106.27 & 106.68 & 107.36 & 107.45 & 107.98 \\
\hline 1978 & 105.72 & 105.83 & 106.17 & 106.05 & 106.13 & $\begin{array}{r}106.27 \\
\text { Cros }\end{array}$ & 105.47 & $\begin{array}{l}106.07 \\
1\end{array}$ & 106.13 & 106.49 & 107.22 & 107.30 & 107.79 \\
\hline 1973 & 103.74 & 104.41 & 104.51 & 104.53 & 104.68 & 104.89 & 103.24 & 104.10 & 104.41 & & & 104.72 & 104.81 \\
\hline 1975 & 103.94 & 104.58 & 104.70 & 104.75 & 104.77 & 105.06 & 103.50 & 104.44 & 104.65 & 104.80 & 104.88 & 105.04 & 105.33 \\
\hline 1976 & 104.04 & 104.78 & 104.95 & 104.91 & 104.98 & 105.31 & 103.66 & 104.66 & 104.86 & 105.01 & 105.18 & 105.26 & 105.30 \\
\hline 1977 & 103.95 & 104.82 & 104.93 & 105.05 & 105.11 & 105.43 & 103.66 & 104.38 & 104.85 & 104.99 & 105.11 & 105.25 & 105.32 \\
\hline 1978 & 104.09 & 104.71 & 104.75 & 104.82 & 105.01 & 105.20 & 103.63 & 104.46 & 104.65 & 104.78 & 104.78 & 104.95 & 105.00 \\
\hline
\end{tabular}


Table 3.--Differences between observed and computed average annual heads at near-cluster piezometer locations in the Yuma area

[Amount by which computed values exceed $(+)$ or are less than (-) observed values, in feet]

\begin{tabular}{|c|c|c|c|c|c|c|}
\hline \multirow{2}{*}{ Year } & \multicolumn{6}{|c|}{ Piezometer number } \\
\hline & $A Z 1$ & $\mathrm{AZ2}$ & AZ3 & CA1 & CA2 & CA \\
\hline & \multicolumn{6}{|c|}{ Cross section 18} \\
\hline 1974 & +0.15 & +0.09 & -0.08 & +0.03 & +0.13 & -0.01 \\
\hline 1975 & +0.09 & +0.11 & -0.07 & +0.05 & +0.18 & -0.04 \\
\hline 1976 & +0.06 & +0.03 & -0.12 & -0.03 & +0.10 & -0.0 \\
\hline 1977 & +0.16 & +0.10 & -0.02 & +0.21 & +0.17 & -0.1 \\
\hline \multirow[t]{2}{*}{1979} & +0.15 & +0.17 & -0.04 & +0.13 & +0.15 & +0.30 \\
\hline & \multicolumn{6}{|c|}{ Cross section 17} \\
\hline 1974 & -0.12 & +0.01 & -0.05 & +0.02 & +0.00 & +0.07 \\
\hline 1975 & -0.20 & -0.06 & -0.24 & -0.02 & -0.02 & -0.06 \\
\hline 1976 & -0.21 & -0.06 & -0.19 & -0.07 & +0.04 & -0.0 \\
\hline 1977 & -0.30 & -0.12 & -0.35 & -0.16 & -0.01 & -0.0 \\
\hline \multirow[t]{2}{*}{1978} & -0.02 & +0.10 & +0.03 & +0.05 & +0.05 & +0.06 \\
\hline & \multicolumn{6}{|c|}{ Cross section 16} \\
\hline 1973 & -0.06 & -0.12 & -0.13 & +0.04 & -0.34 & -0.21 \\
\hline 1974 & -0.01 & -0.07 & -0.05 & +0.05 & -0.25 & \\
\hline 1975 & -0.00 & -0.03 & -0.04 & +0.15 & -0.19 & -0. \\
\hline 1976 & +0.07 & -0.04 & +0.01 & +0.13 & -0.17 & -0.1 \\
\hline 1977 & +0.08 & -0.04 & -0.02 & +0.16 & -0.18 & -0.0 \\
\hline \multirow[t]{2}{*}{1978} & -0.07 & -0.15 & -0.12 & -0.00 & -0.27 & \\
\hline & \multicolumn{6}{|c|}{ Cross section 15} \\
\hline 1974 & -0.03 & +0.15 & -0.06 & +0.09 & -0.08 & -0.1 \\
\hline 1975 & -0.02 & +0.14 & -0.01 & +0.10 & -0.05 & -0.0 \\
\hline 1976 & -0.09 & +0.08 & -0.01 & +0.09 & $-0.0 \theta$ & -0.1 \\
\hline 1977 & -0.03 & +0.11 & -0.03 & +0.15 & -0.07 & -0.1 \\
\hline \multirow[t]{2}{*}{1976} & +0.12 & +0.24 & +0.02 & +0.30 & +0.07 & -0.1 \\
\hline & \multicolumn{6}{|c|}{ Eross section 14} \\
\hline 1974 & +0.10 & +0.00 & -0.26 & +0.20 & -0.20 & -0.1 \\
\hline 1975 & +0.12 & -0.01 & -0.23 & +0.30 & -0.07 & -0.0 \\
\hline 1976 & +0.17 & +0.02 & -0.10 & +0.19 & -0.16 & -0.0 \\
\hline 1977 & +0.23 & +0.10 & -0.07 & +0.13 & -0.19 & -0.0 \\
\hline \multirow[t]{2}{*}{1978} & \multirow{2}{*}{\multicolumn{6}{|c|}{ Cross segtion 13}} \\
\hline & & & & & & \\
\hline 1974 & +0.09 & +0.04 & +0.09 & -0.04 & +0.02 & -0.14 \\
\hline 1975 & +0.10 & +0.06 & +0.14 & -0.10 & +0.01 & -0.14 \\
\hline 1976 & +0.05 & +0.03 & +0.09 & -0.02 & -0.07 & -0.10 \\
\hline 1977 & -0.02 & -0.03 & +0.07 & -0.18 & -0.10 & -0.21 \\
\hline \multirow[t]{2}{*}{1978} & -0.02 & -0.07 & -0.04 & -0.32 & -0.07 & -0.21 \\
\hline & \multicolumn{6}{|c|}{ Cross section 11} \\
\hline 1974 & +0.07 & +0.09 & -0.01 & -0.05 & +0.03 & +0.01 \\
\hline 1975 & +0.06 & -0.14 & -0.19 & -0.07 & -0.04 & -0.03 \\
\hline 1976 & +0.14 & -0.02 & -0.17 & -0.16 & -0.11 & -0.0 \\
\hline 1977 & +0.15 & -0.06 & -0.24 & -0.04 & -0.00 & -0.29 \\
\hline \multirow[t]{2}{*}{1979} & +0.01 & -0.16 & -0.32 & -0.11 & -0.10 & -0.11 \\
\hline & \multicolumn{6}{|c|}{ Cross section 10} \\
\hline 1974 & +0.14 & +0.21 & +0.04 & +0.11 & -0.01 & +0.00 \\
\hline 1975 & +0.08 & +0.24 & -0.05 & +0.08 & -0.22 & -0.13 \\
\hline 1976 & -0.02 & +0.14 & -0.07 & +0.11 & -0.18 & -0.12 \\
\hline 1977 & -0.03 & +0.16 & -0.15 & +0.02 & -0.28 & -0.26 \\
\hline 1979 & +0.03 & +0.10 & -0.25 & & -0.06 & \\
\hline
\end{tabular}


Table 3.--Differences between observed and computed average annual heads at near-cluster piezometer locations in the Yuma area-Continued

\begin{tabular}{|c|c|c|c|c|c|c|}
\hline \multirow{2}{*}{ Year } & \multicolumn{6}{|c|}{ Piezometer number } \\
\hline & $A Z 1$ & $A Z 2$ & $A Z 3$ & CA1 & CA2 & CA \\
\hline & \multicolumn{6}{|c|}{ Cross section? } \\
\hline 1974 & +0.15 & +0.14 & +0.16 & +0.02 & +0.03 & +0.03 \\
\hline 1975 & +0.28 & +0.20 & +0.25 & +0.08 & +0.06 & +0.02 \\
\hline 1976 & +0.27 & +0.13 & +0.14 & +0.15 & -0.04 & -0.01 \\
\hline 1977 & +0.33 & +0.11 & +0.13 & +0.11 & -0.00 & -0.06 \\
\hline \multirow[t]{2}{*}{1978} & +0.27 & +0.11 & +0.13 & +0.11 & +0.02 & -0.01 \\
\hline & & & \multicolumn{4}{|c|}{ Cross section 8} \\
\hline 1973 & +0.05 & +0.01 & -0.04 & +0.06 & -0.01 & -0.04 \\
\hline 1974 & +0.01 & -0.01 & -0.06 & +0.04 & -0.02 & -0.03 \\
\hline 1975 & +0.14 & +0.06 & -0.01 & +0.02 & -0.01 & -0.01 \\
\hline 1976 & +0.06 & -0.03 & -0.07 & +0.05 & +0.02 & -0.01 \\
\hline 1977 & -0.04 & -0.07 & -0.15 & +0.06 & +0.03 & +0.06 \\
\hline \multirow[t]{2}{*}{1978} & -0.02 & -0.04 & -0.14 & +0.03 & -0.09 & -0.06 \\
\hline & & & \multicolumn{4}{|c|}{ Cross section 7} \\
\hline 1975 & +0.22 & +0.24 & -0.01 & -0.04 & -0.02 & +0.06 \\
\hline 1976 & +0.15 & +0.12 & -0.06 & -0.07 & -0.07 & -0.02 \\
\hline 1977 & +0.16 & +0.14 & -0.00 & -0.03 & -0.04 & -0.02 \\
\hline \multirow[t]{2}{*}{1978} & +0.11 & +0.06 & -0.06 & -0.01 & +0.00 & +0.01 \\
\hline & & & \multicolumn{4}{|c|}{ Cross section $b$} \\
\hline 1975 & -0.28 & -0.14 & -0.01 & -0.18 & -0.16 & +0.11 \\
\hline 1976 & -0.01 & -0.07 & -0.09 & -0.23 & -0.24 & +0.16 \\
\hline 1977 & +0.06 & -0.03 & +0.04 & -0.21 & -0.22 & +0.10 \\
\hline \multirow[t]{2}{*}{1978} & -0.12 & -0.13 & +0.08 & -0.23 & -0.27 & +0.02 \\
\hline & & & \multicolumn{4}{|c|}{ Cross section 5} \\
\hline 1975 & +0.08 & +0.10 & +0.13 & +0.39 & +0.26 & +0.15 \\
\hline 1976 & -0.19 & -0.15 & -0.07 & +0.16 & +0.06 & -0.00 \\
\hline 1977 & -0.14 & -0.11 & -0.07 & +0.09 & +0.05 & +0.00 \\
\hline \multirow{2}{*}{1978} & -0.21 & -0.16 & -0.12 & +0.18 & +0.06 & -0.05 \\
\hline & & & \multicolumn{4}{|c|}{ Cross section 4} \\
\hline 1975 & -0.10 & -0.01 & -0.18 & -0.10 & -0.18 & -0.05 \\
\hline 1976 & -0.08 & +0.03 & -0.18 & -0.05 & -0.19 & -0.03 \\
\hline 1977 & -0.16 & -0.04 & -0.23 & -0.07 & -0.22 & -0.06 \\
\hline \multirow[t]{2}{*}{1979} & -0.23 & -0.08 & -0.21 & -0.07 & -0.28 & -0.09 \\
\hline & & & \multicolumn{4}{|c|}{ Cross section 3} \\
\hline 1975 & +0.29 & +0.15 & +0.06 & -0.63 & -0.34 & -0.27 \\
\hline 1976 & +0.13 & +0.04 & -0.13 & -0.58 & -0.35 & -0.21 \\
\hline 1977 & +0.22 & +0.13 & -0.00 & -0.52 & -0.31 & -0.20 \\
\hline \multirow{2}{*}{1978} & +0.20 & +0.10 & -0.04 & -0.62 & -0.40 & -0.29 \\
\hline & & & \multicolumn{4}{|c|}{ Cross section 2} \\
\hline 1975 & +0.21 & +0.15 & +0.04 & +0.15 & +0.28 & +0.10 \\
\hline 1976 & +0.12 & +0.08 & -0.04 & +0.24 & +0.33 & +0.1 \\
\hline 1977 & +0.17 & +0.13 & -0.03 & +0.14 & +0.24 & +0.05 \\
\hline \multirow[t]{2}{*}{1778} & +0.11 & +0.13 & -0.05 & +0.05 & +0.19 & +0.04 \\
\hline & & & \multicolumn{4}{|c|}{ Cross section 1} \\
\hline 1973 & +0.11 & +0.01 & +0.01 & -0.29 & -0.04 & -0.06 \\
\hline 1975 & +0.14 & +0.07 & +0.05 & -0.34 & +0.07 & +0.02 \\
\hline 1976 & +0.21 & +0.06 & -0.00 & -0.38 & -0.03 & -0.10 \\
\hline 1977 & +0.36 & +0.10 & +0.10 & -0.11 & +0.01 & -0.05 \\
\hline 1978 & +0.10 & +0.03 & +0.08 & -0.33 & -0.02 & -0.07 \\
\hline
\end{tabular}


the cross section on the Arizona side leaves on the California side. At cross section 15, about 15 percent of the flow that enters the cross section on the Arizona side leaves on the California side. Because there is no assurance that these flow components discharge to the river, these components cannot be included in the computation of return flow to the river. The computed flow to the river therefore is reduced by the amount of flow that leaves the model through the opposite far-cluster boundary. Using this procedure, the computed flow to the river from the far-cluster boundaries is always equal to the flow exiting the model through the specified-head blocks that represent the river.

The hydraulic-analysis method computes return-flow estimates for each side of the river for each subreach represented by a cross section. The method as presented cannot determine which diverter should receive the credit for the return flows.

The return-flow estimates that were made during the study are listed in table 4. The estimates of ground-water return flow from the Arizona and California sides of the river are the only such estimates known to the authors. Other estimates of total return flow for the Yuma reach, however, can be made using surface-water budgets. For comparison purposes, water-budget estimates of ground-water return flow were made for 1975-78 for the reach from Laguna Dam near cross section 18 to the international boundary near cross section 1 . In the water budgets, ground-water return flow was estimated as the difference between known or measured inflows and outflows to the reach. Additionally, the U.S. Bureau of Reclamation has made other estimates of ground-water return flow using a salinity budget for the reach from Imperial Dam to the international boundary near cross section 1 ( $E$. $E$. Burnett, U.S. Bureau of Reclamation, written commun., 1980). The water budgets and the salinity budgets are not independent in that both use many of the same annual surface-water flow quantities. Some of the surface-water flow quantities used in the budgets are much larger than the ground-water return-flow quantities. Small errors in the surfacewater flow quantities therefore may result in large errors in the estimated ground-water return flow. The results of the three methods, however, indicate general agreement in the magnitude and year-to-year trend of the ground-water return flow for $1975-78$ (fig. 3 ).

The results of the hydraulic-analysis method are estimates of the annual return-flow quantities rather than measurements. Groundwater return-flow quantities cannot be estimated to the same degree of accuracy that surface-water return-flow quantities can be measured. The accuracy or reliability of the ground-water return-flow quantities estimated by the hydraulic-analysis method cannot be assessed because of subjectivity in the trial-and-error calibration process. Return-flow quantities for the entire Yuma reach, however, are probably more accurate than those estimated for individual cross sections. A major advantage of the hydraulic-analysis method over the water-budget and salinity-budget methods is that estimates can be made of the amount of return flow entering the river from each side. 


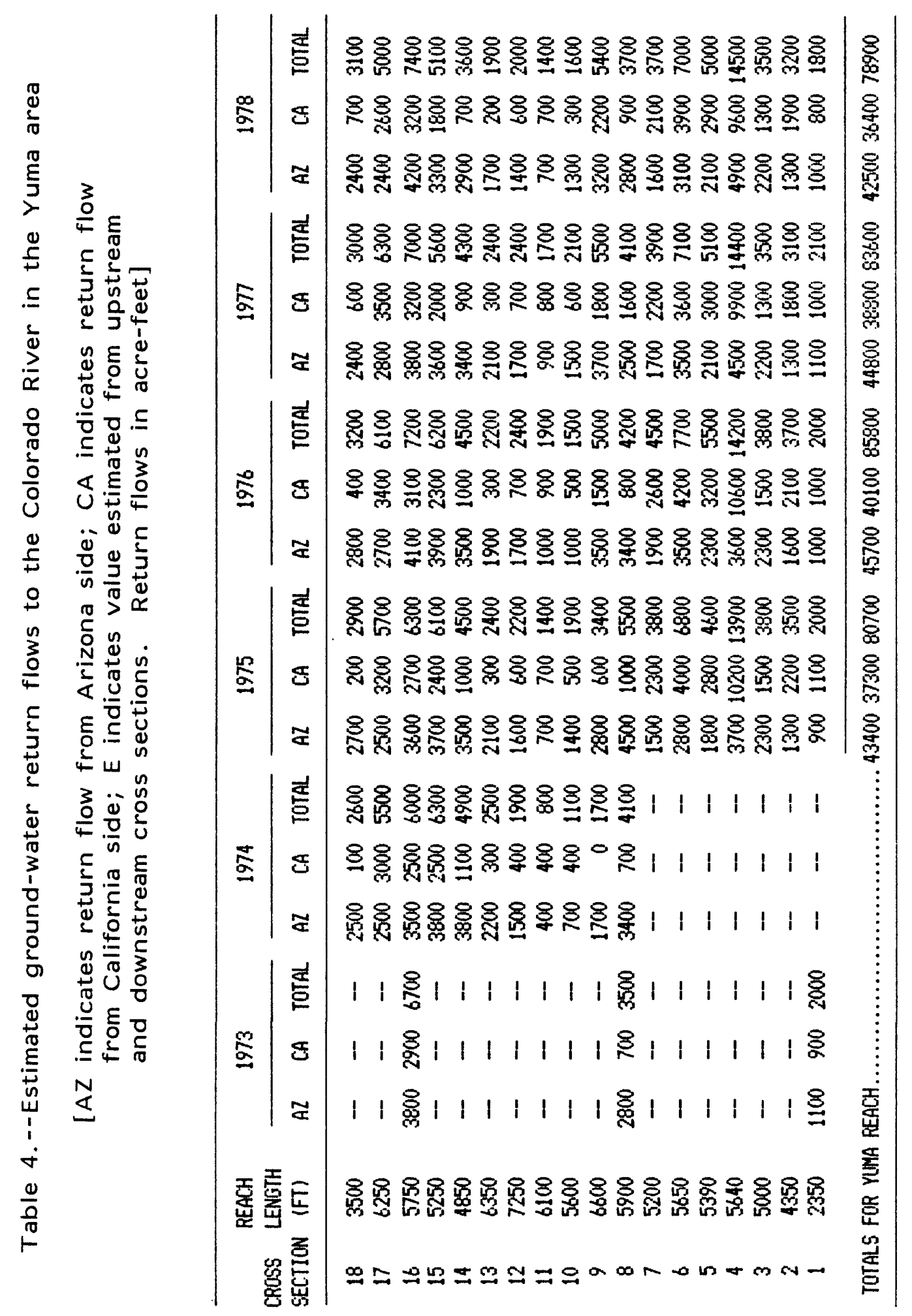


Future Estimation of Return Flow

The hydraulic-analysis method as presented herein can be used for estimation of ground-water return flow for future years. Application of the method will involve collecting data in the piezometers and the river, estimating average annual heads from the data, and using the average annual heads in the steady-state ground-water flow models. Collection and processing of data probably will be the most timeconsuming and costly task in the process of ground-water return-flow estimation.

An analysis was performed to gain insight on the effect of greatly increasing the time period between measurements. Average annual heads in the river and at the piezometer locations were estimated from data obtained at the time of the monthly visit to the cross-section sites. The monthly data represented actual field readings that were separate from the data obtained every 3 hours on the recorders. The annual average heads were simple to compute from the monthly field readings.

At one point in the calibration, return-flow estimates had been made at every cross section in the Yuma reach for 1976. These estimates were recomputed using the average heads from the monthly data. The total return flow for the Yuma reach computed using these data differed from the total return flow using the 3-hour data by about 2 percent. Return flows for individual cross sections differed from the previously computed values by considerably more than 2 percent; however, the differences appear to be random in magnitude and sign (fig. 47).

The foregoing analysis does not attempt to define the proper level of data collection but does indicate that fewer data will suffice for long-term monitoring under the existing flow regimen. The effects of reducing data collection in time (increasing time between measurements) and in space (reducing the number of piezometers and river-stage gages) need to be evaluated. The following questions should be addressed.

1. What is the sensitivity of the computed return flows to errors in average annual heads?

2. What errors in estimating average annual heads are associated with various levels of data collection?

3. What are the costs associated with various levels of data collection?

With answers to these questions, a decision can be made regarding an appropriate level of data collection.

Future changes in the hydrologic regimen of the area may alter the data needs for return-flow estimation with the hydraulic-analysis method. For example, during sustained periods of high river stages, 


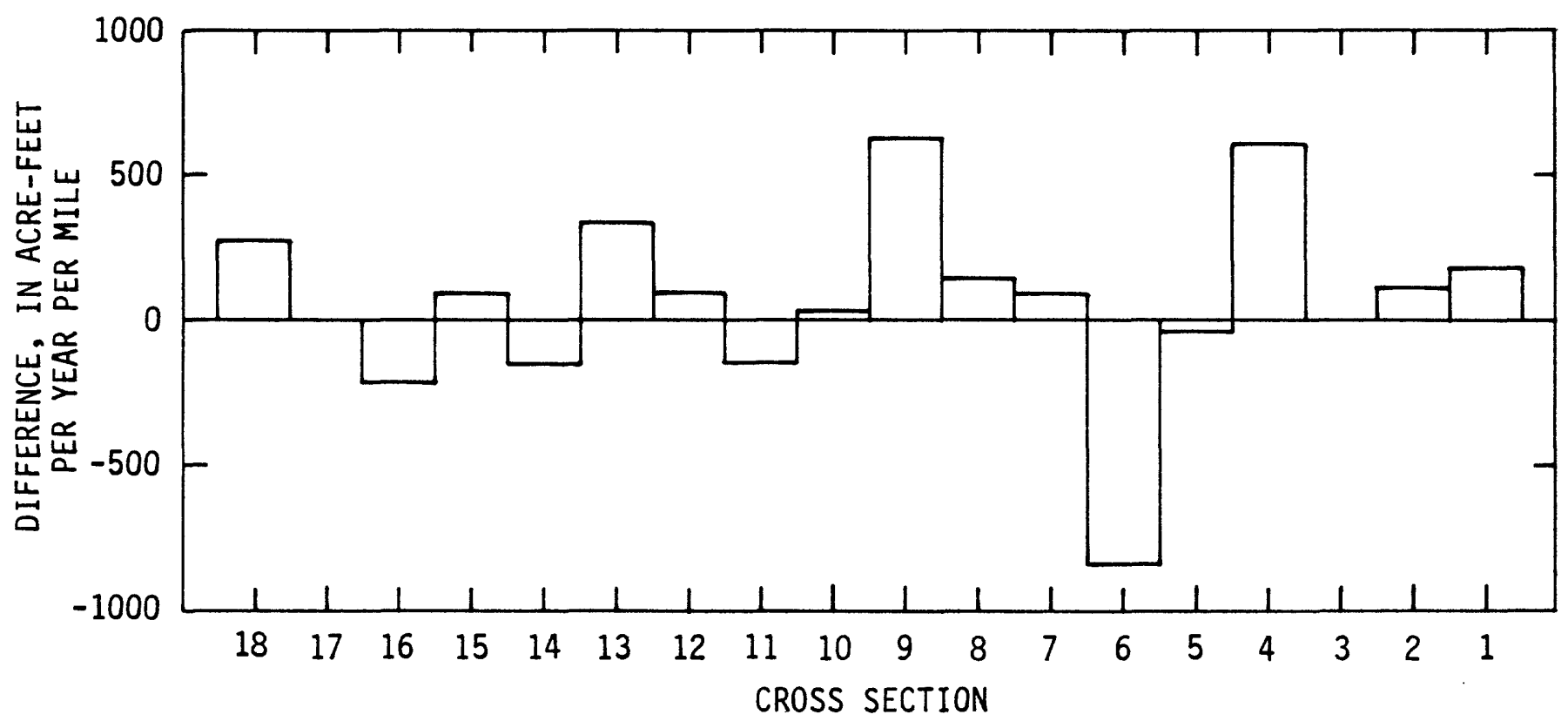

Figure 47.--Differences in return-flow rates for 1976 at cross sections in the Yuma reach computed on the basis of monthly data and 3-hour data. Positive values indicate amount by which return-flow estimates using monthly data exceeded estimates using 3-hour data. 
such as occurred in 1979 and 1980, land around many of the piezometers would be inundated. For such periods, ground-water heads farther away from the river would be needed to define the gradients to the river. In contrast, significant lowering of the river stages by channelization could necessitate repositioning river-stage gages, deepening shallow piezometers, and revising some of the models. Increased ground-water pumping near any of the cross sections, such as occurred near cross sections 12 and 6 , could cause violations of the assumptions made in applying the method.

In summary, future analyses are needed to determine the amount of data required to effectively and efficiently compute average annual gradients to the river. Prudent application of the method will include a brief evaluation of the hydrologic regimen of the area.

\section{REFERENCES CITED}

Carter, R. W., and Anderson, I. E., 1963, Accuracy of current-meter measurements: American Society of Civil Engineers Journal, v. 89, no. HY 4, p. 105-115.

Cooley, R. L., 1972, Numerical simulation of flow in an aquifer overlain by a water table aquitard: Water Resources Research, V. 8, no. 4, p. 1046-1050.

1977, A method of estimating parameters and assessing reliability for models of steady state groundwater flow-1. Theory and numerical properties: Water Resources Research, v. 13 , no. 2 , p. 318-324.

Larson, S. P., 1978, Direct solution algorithm for the two dimensional ground-water flow model: U.S. Geological Survey Open-File Report 79-202, 22 p.

Loeltz, O. J., and Leake, S. A., 1983, A method for estimating groundwater return flow to the lower Colorado River in the Yuma area, Arizona and California-Executive summary: U.S. Geological Survey Water-Resources Investigations Report $83-4221,8 \mathrm{p}$.

Lohman, S. W., 1979, Ground-water hydraulics: U.S. Geological Survey Professional Paper 708, 70 p.

Metzger, D. G., Loeltz, O. J., and Irelan, Burdge, 1973, Geohydrology of the Parker-Blythe-Cibola area, Arizona and California: U.S. Geological Survey Professional Paper 486-G, 130 p.

Neuman, S. P., and Yakowitz, Sidney, 1979, A statistical approach to the inverse problem of aquifer hydrology-1. Theory: Water Resources Research, v. 15, no. 4, p. 845-860. 
Olmsted, F. H., Loeltz, O. J., and Irelan, Burdge, 1973, Geohydrology of the Yuma area, Arizona and California: U.S. Geological Survey Professional Paper 486-H, 227 p.

Sellers, W. D., and Hill, R. H., eds., 1974, Arizona climate 1931-1972: Tucson, University of Arizona Press, $616 \mathrm{p}$.

Trescott, P. C., Pinder, G. F., and Larson, S. P., 1976, Finitedifference model for aquifer simulation in two dimensions with results of numerical experiments: U.S. Geological Survey Techniques of Water-Resources Investigations, book 7, chapter C1, $116 \mathrm{p}$.

U.S. Bureau of Reclamation, 1979, Ground-water status report, 1978, Yuma area, Arizona-California: U.S. Bureau of Reclamation duplicated report, $55 \mathrm{p}$.

U.S. Supreme Court, 1964, State of Arizona, plaintiff $v$. State of California, et al., defendants: Decree-March 9, 1964, no. 8, original, $14 \mathrm{p}$.

Yeh, W. W.-G., and Yoon, Y. S., 1981, Aquifer parameter identification with optimum dimension in parameterization: Water Resources Research, v. 17, no. 4, p. 664-672. 